\author{
Universidade de S̃̃o Paulo \\ Faculdade de Filosofia, Letras e Ciências Humanas \\ Departamento de Letras Orientais \\ Programa de Pós-graduação de Estudos Judaicos e Árabes \\ Área de Estudos Árabes
}

Renato Roschel Cristi

A TEORIA ECONÔMICA NA COSMOVISÃO DE IBN KHALDUN

V.1

São Paulo 
Autorizo a reprodução e divulgação total ou parcial deste trabalho, por qualquer meio convencional ou eletrônico, para fins de estudo e pesquisa, desde que citada a fonte.

Catalogação na Publicação

Serviço de Biblioteca e Documentação

Faculdade de Filosofia, Letras e Ciências Humanas da Universidade de São Paulo

CC933t

Cristi, Renato Roschel

A teoria econômica na cosmovisão de Ibn Khaldun/ Renato Roschel Cristi ; orientador Miguel Atiie

Filho. - São Paulo, 2017.

$134 \mathrm{f}$.

Dissertação (Mestrado) - Faculdade de Filosofia, Letras e Ciências Humanas da Universidade de São Paulo. Departamento de Letras Orientais. Área de concentração: Estudos Judaicos e Árabes.

1. Ibn Khaldun. 2. Economia. 3. História Do Pensamento Econômico. 4. Filosofia. 5. Islamismo (história). I. Filho, Miguel Atiie, orient. II. Título. 


\author{
Universidade de São Paulo \\ Faculdade de Filosofia, Letras e Ciências Humanas \\ Departamento de Letras Orientais \\ Programa de Pós-graduação de Estudos Judaicos e Árabes \\ Área de Estudos Árabes
}

RENATO ROSCHEL CRISTI

\title{
A TEORIA ECONÔMICA NA COSMOVISÃO DE IBN KHALDUN
}

Dissertação apresentada ao Programa de PósGraduação em Estudos Judaicos e Árabes, na Área de Estudos Árabes, da Faculdade de Filosofia, Letras e Ciências Humanas Departamento de Letras Orientais para a obtenção do título de Mestre em Estudos Árabes

Orientador: Prof. Dr. Miguel Attie Filho

$$
\text { V. } 1
$$

São Paulo 
Para Daniela, Beatrice e Clarice 


\section{AGRADECIMENTOS}

Esse texto não seria possível se não fosse a paciência e a dedicação do mestre Prof. Dr. Miguel Attie Filho. Seus conselhos foram e serão sempre decisivos em toda minha produção e trajetória intelectual. Agradeço imensamente a confiança a mim dedicada e espero ser digno de um dia estar à altura de suas expectativas.

Também agradeço todos os professores do Departamento de Letras Orientais, sem os quais essa pesquisa não seria possível: Safa Alferd Abou Chahla Jubran, Mamede Mustafá Jarouche, Arlene Elizabeth Clemesha, Alexandre Goes Leone e Moacir Aparecido Amâncio. Todos sempre prontos a ajudar na pesquisa desse trabalho.

Não posso deixar de citar e reconhecer a incalculável ajuda oferecida pelos membros do grupo Tradução e Pesquisa de Filosofia Árabe e História do Pensamento. Sem os conselhos, conversas, leituras e críticas feitas pelos colegas Christiane Damien, Daniel Alonso de Araujo, Marina Diel e Mateus Domingues esse trabalho não estaria completo.

Para as amadas Daniela, Beatrice e Clarice peço desculpas por todos os finais de semana que elas ficaram sem mim e, pacientemente, aceitaram minha reclusão no escritório de casa lendo textos, escrevendo e reescrevendo esse trabalho durante sábados, domingos e madrugadas a fio.

Por último, espero sinceramente que essa tese possa representar uma pequena, porém honesta, contribuição na pesquisa da história do pensamento em língua árabe. 
"Yo soy yo y mi circunstancia, y si no la salvo a ella no me salvo yo" (GASSET, 2008, p. 12) 


\section{RESUMO}

O pensador do século XIV Ibn Khaldun (1332-1406) é considerado por muitos um precursor das ciências sociais e da filosofia da história. Sua obra, Os Prolegômenos - ou Filosofia Social, principal objeto de estudo no presente trabalho, é um marco na sociologia geral, na história e na economia. O objetivo desta dissertação não é estudar as teorias presentes nesse texto em minuciosos detalhes. Ao invés disso, colocaremos Ibn Khaldun sob uma luz diferente. Trataremos aqui da cosmovisão que está por trás dos escritos desse pensador. Acreditamos que ele tentou conciliar um método até então novo de fazer pesquisa histórica, sociológica e econômica, baseado na lógica aristotélica e em certo cuidado com os fatos, porém, sempre com a intenção de enquadrar suas descobertas em uma moldura teológica fundamentada no Alcorão. A partir desse esforço, buscaremos demonstrar como conceitos econômicos, políticos e religiosos fundamentam, em Os Prolegômenos, certa cosmovisão fatalista e cíclica da história e em quais pontos ela pode ser considerada extremamente autoral e exemplar para uma melhor compreensão do mundo islâmico do século XIV.

\section{ABSTRACT}

The 14th century thinker Ibn Khaldun (1332-1406) is considered by many to be a forerunner of the social sciences and the philosophy of history. His work, The Muqaddimah: an introduction to history, main object of study in the present work, is a milestone in general sociology, history and economics. The purpose of this dissertation is not to study the theories present in Ibn Khaldun's text in minute detail. Instead, we will put Ibn Khaldun in a different light. We will deal here with the worldview behind the writings of this thinker. We believe that he tried to reconcile a hitherto new method of doing historical, sociological and economic research, based on Aristotelian logic and some caution with facts, but always with the intention of conforming his findings in a theological framework based on the Quran. From this effort, we will try to demonstrate how economic, political and religious concepts in The Muqaddimah ground for a certain fatalistic and cyclical worldview on history and at what points it can be considered extremely authorial and exemplary for a better understanding of the Islamic world of 14 th century.

Key-words: Ibn Khaldun, trabalho, filosofia, história do pensamento econômico, islamismo 


\section{SUMÁRIO}

INTRODUÇÃO




\section{INTRODUÇÃO}

Circunstâncias são mães de inúmeras invenções. Movidos por elas muitos seres humanos tornam-se criadores. Produzem soluções e conceitos. Decifram e ampliam nossos conhecimentos. Ibn Khaldun integra esse grupo. Sua obra Os Prolegômenos é resultado direto dos contextos vividos pelo autor durante boa parte do século XIV e os primeiros anos do XV. Ela reflete o empenho para promover a conjunção de três fatores: a análise racional da realidade na qual ele está inserido; o acesso que teve e a utilização que fez do conhecimento existente à época nas sociedades de língua árabe; e a tentativa de harmonização desse universo conceitual a certa compreensão teológica do mundo ${ }^{1}$.

Muçulmano, Ibn Khaldun colocou toda a força da sua inteligência para montar uma arquitetura teórica que invariavelmente remete ao texto sagrado e a um conceito fundamental do islamismo, aquele que entende o Alcorão como "inimitável ( $i$ ’jaz alQur'an), infalível e inalterável" (ISKANDAR, 2007, p. 107). Em razão disso, as concepções econômicas, históricas e filosóficas presentes na sua obra são todas transpassadas e moldadas pelo texto corânico, que serve de base para sua cosmovisão. Igualmente outros pensadores de língua árabe, Ibn Khaldun busca "conciliar a concepção religiosa do mundo com a razão e legitimar a concepção racional de um ponto de vista religioso" (AL-JABRI, 1999, p. 76).

Há, no entanto, fissuras nessa construção. A inovação que reside em estudar fatos sociais de forma mais objetiva obrigou Ibn Khaldun a buscar uma difícil harmonia na dissonância produzida pela mistura de textos religiosos com as conclusões às quais suas análises silogísticas o levavam. Para ele, esse esforço significava investigar, na “pluralidade do 'temporal'” (AL-JABRI, 1999, p. 154), a ascensão e declínio de uma

\footnotetext{
${ }^{1} \mathrm{O}$ texto de Os Prolegômenos, portanto, é profundamente moldado pela utilização do conhecimento como "arma ideológica" (AL-JABRI, 1999, p. 102). Ibn Khaldun apropria-se de conceitos e práticas de análise no intuito de fazer valer determinada concepção sociopolítica promotora de um "Estado maghrebino-andalusi" (AL-JABRI, 1999, p. 154) que, para ele, não poderia ser governado sem "algum grau de cooperação entre o governante e os habitantes, ou pelo menos entre aqueles que tinham interesse na ordem estável" (HOURANI, 2001, p. 147). Sua construção conceitual se fundamenta no pensamento reformador de Ibn Tūmart, que visava "a restauração da pureza original do Islâ" (HOURANI, 2001, p. 169), e ocorre, em boa parte, dentro da "complexa e delicada configuração política" (FROMHERZ, 2010, p. 14, tradução nossa) da dinastia Hafsida (1228-1574), a qual é, ao mesmo tempo, origem e destino de sua obra.
} 
dinastia, separando, no decorrer de sua obra, o efêmero intrínseco ao mundo real da eternidade e plenitude presentes no texto sagrado e na prática religiosa.

Nos escritos de Ibn Khaldun, a corrupção e as variações das sociedades opõemse à natureza invariável e incorruptível que estaria presente no Alcorão (KHALDUN, 1967, p. 583). Paradoxalmente, quanto mais próximas da realidade são as investigações existentes em Os Prolegômenos maior também é o esforço para fazê-las coincidir com a palavra de Deus. Nesse sentido, o texto impõe uma inescapável moldura corânica ao frescor das muitas descobertas, das surpreendentes análises e das soluções teóricas. Tal relação é central na construção da identidade de Os Prolegômenos e da sua "unidade problemática"2 (AL-JABRI, 1999, p. 65).

Em razão desse encontro entre o perene da religião e o efêmero do mundo real, o trabalho de Ibn Khaldun se apresenta como um capítulo de uma história do pensamento econômico mais ampla que as convencionais. Nesse sentido, é possível afirmar que $O s$ Prolegômenos ampliam conceitos econômicos de pensadores como al-Dimashqi, que, por sua vez, utilizou ideias do autor romano Bryson Arabus (ESSID, 1995, p 221). Neles, já está presente, por exemplo, a mesma percepção khalduniana de que o comerciante contribuía positivamente às sociedades ao ligar regiões onde há excesso de um produto com outras que sofrem com a escassez do mesmo (BACKHOUSE, 2002, p.36).

Portanto, o livro Os Prolegômenos de Ibn Khaldun está dentro do mesmo processo que levou Leonardo de Pisa (Fibonacci) a importar para o norte da Itália, no meio do século XIII, a aritmética e a contabilidade desenvolvidas pelos árabes na Argélia (LOWRY, 2003, p. 13). Conhecimentos estes que o próprio Ibn Khaldun também vinculava às transações comerciais (KHALDUN, 1960, p.125). É nessa disseminação descontínua que algumas teses produzidas por pensadores do mundo árabe podem ter se propagado em outras culturas. Segundo Jürgen Renn e Malcolm D. Hyman (2012, p. 32, tradução nossa),

\footnotetext{
${ }^{2}$ Segundo Mohammed Abed Al-Jabri, "uma problemática é uma rede de relações tecidas, no seio de um dado pensamento, num conjunto de problemas que se inter-relacionam de tal maneira que é impossível resolvê-los separadamente, pois só podem ser resolvidos - no nível teórico - globalmente. Em outras palavras, uma problemática é uma teoria cujas condições de construção ainda não estão reunidas, uma teoria em devir, uma propensão à estabilização do pensamento" (AL-JABRI, 1999, p. 65-66).

${ }^{3} \mathrm{O}$ texto de Bryson, Oikonomikos logos (Gestão de uma propriedade), que se tornou o Taymūr no mundo árabe, é bastante singular em termos de legado. Em seu tratado, Arabus aborda várias questões econômicas, a mais relevante: como gastar dinheiro? (SWAIN, 2013, p. VII).
} 
(...) durante longos períodos da história humana, o conhecimento foi disseminado em conexão com o poder e as estruturas de crença. Assim, ele se espalhou por longas distâncias ou em vastas áreas como um subproduto de outros processos de difusão, por exemplo, a expansão dos impérios ou a difusão das religiões. Esses processos podem ser de caráter transregional e transcultural, mas também podem ser de tipo corredor, conectando regiões distantes por uma cadeia de transmissão fina, muitas vezes indireta e frágil, por exemplo, uma rota comercial como a Rota da Seda ou a missão jesuíta na China. Tais caminhos são especiais. Eles mantém o mundo unido, mas muita vez apagam ou mistificam os parceiros mais distantes dessa comunicação.

Aqui, tentaremos mostrar que a cosmovisão presente na obra de Ibn Khaldun é, em boa parte, resultado dessa construção e parte integrante dessa tradição, sem esquecer que seu texto, apesar de estar ligado aos pensadores que lhe foram anteriores, carrega em si muitas "novidades" quando enquadrado dentro da história do pensamento econômico.

Também mostraremos o quanto a realidade marcou a obra de Ibn Khaldun, um homem mergulhado em disputas políticas e tragédias familiares e sociais. Um contexto que, de certa forma, se inicia no século XII, quando a família de Ibn Khaldun deixa o território espanhol e migra para Túnis. Nesse momento, segundo Talbi (2010, p. 86), a

(...) chama da cultura africana, em sua forma andaluzo-magrebina, brilhou pela última vez, antes que sua luz, cada vez mais vacilante, se extinguisse na obscuridade da decadência. O colapso demográfico, gerador de estagnação, de atraso ou regressão econômica provocou a atrofia cultural. A seiva cessou de fluir nos ramos secos e asfixiados. Foi então que a herança acumulada nos confins setentrionais da África e na Espanha muçulmana foi recolhida por uma Europa que, em plena expansão demográfica, descobriu, com entusiasmo, seu inestimável valor cultural e tático. Esta herança constituiu poderoso estímulo para a Renascença europeia.

O texto de Os Prolegômenos e as novidades que ele apresenta foram construídos dentro de um ambiente "transnacional", porém marcadamente decadente e socialmente instável. O próprio autor tinha uma profunda compreensão das incertezas políticas e sociais de sua época e total consciência de certo processo de transmissão do conhecimento. Conforme Ibn Khaldun (1960, p.125),

(...) antes do estabelecimento do Islão, os povos mais devotados ao culto destas ciências foram os dois poderosos Impérios, o da Pérsia e o da Grécia ou Rum. Foi me dito que, entre estes povos, os mercados da Ciência estavam abarrotados, porque a Civilização tinha feito ali grandes progressos e que anteriormente à promulgação do Islão exerciam ambos uma dominação vasta e muito extensa. Foi a razão destas ciências transbordarem, como oceanos, nas suas províncias e nas suas grandes cidades. 
Essa característica transnacional do conhecimento é enfatizada pelo próprio autor. Segundo Ibn Khaldun, quando o califa Al-Mamun, grande admirador das ciências, chegou ao poder, o líder abássida (KHALDUN, 1960, p. 128-129)

(...) mandou seus embaixadores juntos aos reis Gregos, com o fim de traduzir
para o árabe as obras científicas gregas e introduzi-las no próprio império
(árabe). Com este fito, mandou partir (com os embaixadores) muitos
intérpretes, e conseguiu recolher a totalidade destes tratados. Desde então, os
muçulmanos que se ocupavam de ciências especulativas aplicaram-se ao
estudo destas ciências em todos os seus ramos e delas se tornaram muito
conhecedores. Avançaram tanto em investigações que se acharam em
condições a refutar grande número de opiniões emitidas pelo Primeiro
MESTRE Aristóteles. Foi às doutrinas deste que se apegaram
particularmente, quer para refutá-las, quer para sustentá-las, porque de todos
os filósofos era o mais afamado. Compuseram muitos tratados sobre as
ciências e (tendo adquirido grande soma de saber) ultrapassaram seus
predecessores.

O material coletado pelos intérpretes de Al-Mamun foi absorvido e de certa forma transformado por pensadores como Al-Fārābī, Avicena e Averróis (KHALDUN, 1960, p. 129). A obra Os Prolegômenos faz parte dessa história. É um capítulo consciente dela. Sua produção representa a criação e transferência de conhecimento através de redes comerciais e da expansão de dinastias, as quais, por sua vez, permitiam uma espécie de colaboração internacional altamente complexa e primordialmente voltada para a manutenção e expansão de um determinado poder. Para os árabes, traduzir livros significava conhecer a ciência de povos como os gregos, os romanos, os persas e, a partir delas, produzir novos saberes e utilizá-los nas disputas internas pelo poder, posto que a "filosofia nunca foi, na sociedade islâmica, um luxo intelectual. Pelo contrário, já no momento de seu nascimento, ela foi um discurso ideológico militante" (AL-JABRI, 1999, p. 89). Logo, participar ativamente da produção de conhecimento significava também permanecer no centro do poder.

O mundo do pensamento em língua árabe, no entanto, possui suas características. Sabemos, por exemplo, que para os pensadores muçulmanos as filosofias de Platão e Aristóteles tinham mais semelhanças do que diferenças. Prova disso é o livro Concordância de Platão e Aristóteles produzido por Al-Fārābī (GILSON, 2001, p. 427). Tal título, além de indicar certa peculiaridade do pensamento em língua árabe, mostra, segundo Gilson (2001, p. 427)

(...) quão inexato é sustentar que a filosofia árabe não fez mais que prolongar a de Aristóteles. Muito pelo contrário, convencidos de que o pensamento de Aristóteles estava, no fundo, de acordo com o de Platão, os árabes fizeram grandes esforços para conciliá-los. Aliás, não esqueçamos que, como os 
ocidentais, os árabes tinham, ademais, uma religião, que deviam levar em conta e que influenciou suas doutrinas. Como o do Antigo Testamento, o Deus do Corão é uno, eterno, onipotente e criador de todas as coisas; portanto, os filósofos árabes defrontaram-se, antes dos cristãos, com o problema de conciliar uma concepção grega do ser e do mundo com a noção bíblica de criação.

Ibn Khaldun enfrenta esse mesmo desafio. Seu texto resulta da chegada do pensamento grego e latino, ou seja, de ideias forâneas ao mundo árabe e da mistura das mesmas à jurisprudência de fundo malikita (FROMHERZ, 2010, p. 49) e uma escola de pensamento que "desestimulava a especulação teológica" (HOURANI, 2001, p. 178). Por conseguinte, sua resposta surge da utilização dessas ferramentas conceituais estrangeiras para explicar realidades sociais marcadamente islamizadas.

O autor de Os Prolegômenos, ao retrabalhar tais conceitos em um contexto social diferente, acaba por elaborar ideias completamente novas apesar de permanecer dentro da tradição e da história do conhecimento em língua árabe, produzindo ao fim uma narrativa capaz apresentar os acontecimentos "sob uma forma racionalmente inteligível” (AL-JABRI, 1999, p. 151). Assim, ele repete um método utilizado por outros pensadores já que "apoiar-se na tradição, ou usar descobertas passadas, constitui um procedimento judicioso para todo investigador intelectual” (BARNES, 2005, p. 32).

Esse esforço não é acidental. Da mesma maneira que Aristóteles, o qual era profundamente "consciente de sua própria posição no final de uma longa linha de pensadores" (BARNES, 2005, p. 32) e possuía "um forte sentido da história intelectual e do próprio lugar que nela ocupava" (BARNES, 2005, p. 32), Ibn Khaldun também sabia da importância de sua pesquisa e tinha "conhecimento do trabalho dos historiadores" (AL-JABRI, 1999, p.150). Ele se propõe a transformar a história em "uma ciência fundamentada na demonstração" (AL-JABRI, 1999, p.150), elevando-a assim de "mera atividade de compilação" (AL-JABRI, 1999, p.150) para uma "prática científica” (AL-JABRI, 1999, p.150). Para Ibn Khaldun, estudioso igualmente cônscio do lugar que ocupava na história do pensamento em língua árabe, tal trabalho intelectual só seria possível se resultasse dos seguintes procedimentos (IBN KHALDUN, 1958, p. 4-5):

(...) o exame e a verificação dos fatos, a investigação cuidadosa das causas que os precederam, o conhecimento profundo da maneira como os acontecimentos se sucederam, e como começaram. 
O autor de Os Prolegômenos, portanto, insere sua visão sobre a História em algo que, "em sua essência, constitui um ramo importante da Filosofia e merece ser colocada entre as Ciências" (KHALDUN, 1958, p. 5), seguindo seu caminho em se tornar parte de uma determinada tradição na produção de conhecimento. Assim, seu texto procura realizar a “'racionalização” da Revelação e da história” (AL-JABRI, 1999, p.145) e, em razão disso, torna-se parte inequívoca de um pensamento econômico e historiográfico rebento do passado e germinador do futuro.

Prova disso é que a concepção cíclica de história e o alicerce divino presentes no texto khalduniano também ocorreram em fontes longínquas. Seguir os mandamentos do Alcorão, aproximar-se deles, torná-los regra para a condução de uma sociedade remete, por exemplo, à noção de justiça de Hesíodo, o qual diz a Perses "ouve a justiça", Díke, “e não aumentes a desmedida", Hýbris (HESÍODO, 2012. p. 85). Ibn Khaldun de certa forma repete Hesíodo, o qual, segundo Jean-Pierre Vernant (2002. p. 28), nos ensina que "a história conta a sucessão de diversas raças de homens que, precedendo-nos na Terra, aparecem e depois desaparecem alternativamente".

Segundo René Schaerer, citado por Vernant (2002, p. 28), as civilizações humanas invariavelmente caminham para a desmedida Hýbris, pois "todas as raças, as melhores e as piores, tiveram do mesmo modo que deixar a luz do sol". Ambos apontam para a paradoxal contradição entre um "mundo divino, em que a ordem é imutavelmente fixada" (VERNANT, 2002. P.28) e um "mundo humano no qual a desordem se instala pouco a pouco e que deve acabar virando inteiramente para o lado da injustiça, da desgraça e da morte" (VERNANT, 2002. P.28). Esse mesmo pensamento, presente em Hesíodo e destacado por Schaerer e Vernant, marca a obra de Ibn Khaldun, o qual acreditava em uma história cíclica de civilizações inexoravelmente fadadas à derrocada e uma concepção do divino como sendo perfeito e imutável. Aliás, segundo Franz Rosenthal, "Ibn Khaldun restringia a influência do Divino apenas ao extraordinário nos assuntos humanos" (ROSENTHAL, 1967, p. 42, tradução nossa).

Essa mesma noção de história cíclica está presente no Antigo Testamento. Em Eclesiastes 1:4-11 é possível ler:

Geração vai, geração vem, e a terra permanece sempre a mesma. O sol se levanta, o sol se põe (...). O vento sopra para o sul, depois para o norte (...). Todos os rios correm para o mar, e o mar nunca transborda (...). O que aconteceu, de novo acontecerá; e o que se fez, de novo será feito: debaixo do 
sol não há novidade. (...) Ninguém se lembra dos antigos, e aqueles que existem não serão lembrados pelos que virão depois deles.

Por ser um texto primordialmente sapiencial, o Eclesiastes, que é carregado do mesmo caráter pessimista que encontramos em Os Prolegômenos, encara a realidade como transitória, onde "tudo é fugaz, uma corrida atrás do vento" (BÍBLIA, Eclesiastes, 1, 14). Assim, Ibn Khaldun reverbera em Os Prolegômenos uma tese que perpassou vários textos clássicos. É possível, por exemplo, ler na obra do historiador Políbio (200 a. C. - 118 a. C.) uma análise dos ciclos históricos e da ascensão e queda de impérios que, por sua vez, ecoava escritos de Ocellus Lucannus e Platão (TROMPF, 1979, p. 4045). Há, portanto, recorrência no pensamento grego, na historiografia romana, nos textos bíblicos e em escritos judaicos da concepção da história repetindo a si mesma (TROMPF, 1979, p. IX).

Por exemplo, Políbio, em sua obra Histórias (VI 3. 9-4. 6), indica que há dois caminhos para a decadência do poder: a primeira provocada pela prosperidade e pelos luxos que ela proporciona (tes epi to kheiron metaboles) - tese extremamente semelhante à de Ibn Khaldun -; e a segunda, resultado da emancipação política da população, a qual, de acordo com o historiador, acabaria na tirania das massas (oclocracia, do grego okhlokratia).

Tempos depois, os escritos de Políbio reapareciam nas obras de Cícero (106 a.C. - 43 a.C.), o qual também tratou dos ciclos políticos e da ascensão e queda de um determinado poder. Em seu livro Histórias (VI 9, 10), Políbio fala ainda da anaciclose teoria retomada séculos depois por Maquiavel nos Discorsi, I, 2 -, que seria o "curso natural ou a ordem segundo a qual as constituições mudam, são transformadas, para depois retornar ao seu estado original" (TROMPF, 1979, p. 5, tradução nossa).

Ibn Khaldun, no entanto, não apenas constata que historicamente nada permanece, ele acresce à essa tese advinda do passado a noção de que o desenvolvimento econômico, por ser mundano, tende inexoravelmente ao luxo e à decadência. Seu livro, assim como o texto bíblico e dos clássicos gregos e latinos, contrapõe o efêmero intrínseco à realidade ao perpétuo e absoluto manifesto nas escrituras sagradas - nesse caso, o Alcorão, que para ele é o "livro fundamental de toda instrução, a fonte de que emanam a religião e as ciências" (KHALDUN, 1960, p. 279). Esse antagonismo conceitual, por sua vez, ocorre em um texto profundamente vinculado aos princípios dedutivos da lógica silogística. Assim, a obra khalduniana, em razão da 
proximidade a certa terminologia filosófica e de seu fundo teológico, resulta em uma visão cíclica da história formada a partir de uma análise mais objetiva dos fenômenos sociais $^{4}$.

Em Os Prolegômenos, o divino apresenta-se como uma espécie de primeiro motor imóvel, onde tudo é eterno, de onde tudo se inicia e para onde tudo retorna. Ele reside na "perfeição inimitável do Corão" (KHALDUN, 1960, p. 321), texto que atua como bússola moral, capaz de produzir e levar à "fé perfeita" (KHALDUN, 1960, p. 54), a qual, por sua vez, impede que os indivíduos cometam "não somente os pecados graves, mas os pequenos também" (KHALDUN, 1960, p. 54). Ao mesmo tempo, o texto propõe uma leitura "realista" do mundo radicalmente lógica e inovadora. Seu realismo é "vernacular, cotidiano e baseado no senso comum, que vai além de apenas registrar os fatos conforme eles ocorrem" (AL-AZMEH, 2003, p. 133, tradução nossa). É dessa constante tentativa de conciliação do racionalismo filosófico, a lei muçulmana e a teologia (NASSAR, 1967, p. 20) que suas ideias econômicas e sua cosmovisão surgem.

É nessa estrutura representativa do momento histórico no qual Ibn Khaldun viveu que se manifesta a arquitetura conceitual do quadro histórico-político de $O s$ Prolegômenos. Ela, de certa forma, segue o modelo proposto por Ibn Tūmart para quem as fontes "utilizadas no estabelecimento das leis da religião são (...) o Corão e a suna e, em certas circunstâncias, o consenso e o raciocínio por analogia" (NIANE, 2010, p. 27).

Ibn Tūmart, no entanto, "condena, efetivamente, o al-kiyās akli (analogia especulativa)" (NIANE, 2010, p. 27). Nesse sentido, a crítica que Ibn Khaldun faz à filosofia é, em boa parte, resultado de profundas mudanças políticas ocorridas dentro do islã e sua vinculação ao pensamento tūmartiano. Ele acredita que desde os almorávidas, inicialmente liderados pelo muçulmano ortodoxo Ibn Yassin, e posteriormente com os almôadas, sob o comando do também rígido líder religioso, Ibn Tūmart, as dinastias só floresceram quando seus governantes eram zelosos seguidores do texto sagrado. Atento

\footnotetext{
${ }^{4}$ É importante destacar que a abordagem de cunho silogístico adotada por Ibn Khaldun está longe de ser a mais objetiva ou mesmo que ela possa ser equiparada às abordagens econômicas da atualidade. Porém, é muito importante indicar que o texto de Ibn Khaldun, apesar de sua peculiaridade e sua profunda ligação com uma compreensão teológica do mundo no qual o autor estava inserido, é um passo na direção de uma compreensão econômica e racional da realidade. Prova disso são seus escritos sobre temas como: valoração do trabalho, distribuição de renda, crescimento econômico, desenvolvimento e da importância do dinheiro, dos preços, de determinadas políticas de controle das finanças públicas, dos ciclos econômicos, da inflação e dos benefícios do comércio.
} 
à história islâmica, Ibn Khaldun é pragmático, pois retira suas conclusões dos fatos. Em razão disso, ele, por analogia, vincula o sucesso de uma sociedade à ortodoxia de seus líderes, à sua capacidade política e militar e à proximidade e observância dos preceitos religiosos pela população e os poderosos.

Destarte, a arquitetura conceitual de Ibn Khaldun pertence ao segundo momento do "pensamento filosófico na sociedade árabe-islâmica" (AL-JABRI, 1999, p. 154), o qual foi "inaugurado epistemologicamente pelas contribuições críticas de Ibn Hazm e Ibn Tūmart” (AL-JABRI, 1999, p. 154). A obra Os Prolegômenos foi produzida em um contexto marcado pelo

conflito político entre o califado abácida, promotor de um pensamento em que o temporal se 'absolutiza' na religião, e um Estado Magrebino-andalusi cuja própria existência constituía a prova de que a pluralidade do 'temporal' podia existir no seio da unidade religiosa (AL-JABRI, 1999, p. 154).

Além de seu característico formato, a semelhança entre o texto de $O s$ Prolegômenos de Ibn Khaldun, o texto corânico - principalmente os versículos 43 e 44 da $35^{\text {a }}$ surata (Fáter) do Alcorão -, o texto bíblico do Eclesiastes e o clássico $O$ trabalho e os dias de Hesíodo indica o quanto ideias realmente poderosas podem ser resilientes 5 . Elas não só resistem aos ciclos das sociedades como ajudam a conformá-los. Transpõem-se de uma tradição para outra ou simplesmente ressurgem em razão de sua forte vinculação com a realidade. Nesse sentido, esse texto também pretende indicar que, em função desse mecanismo intrínseco às ideias, a expressão "pensamento ocidental" indica algo que só poderia existir se o mundo do conhecimento, dos intercâmbios culturais e principalmente do comércio respeitasse os limites e as fronteiras aleatoriamente impostos por governos e guerras e fosse totalmente imune às inevitáveis semelhanças entre distintas sociedades e tempos históricos.

\footnotetext{
${ }^{5}$ Concordamos aqui com a obra clássica de V. Gordon Childe, A prehistorian's interpretation of diffusion. O texto desse arqueólogo, filólogo e historiador propõe o difusionismo, processo pelo qual os traços culturais, ideias ou objetos são difundidos ou transmitidos de uma cultura ou sociedade para outra através de migrações, guerras, comércio ou imitação. Tal fenômeno está presente em Os Prolegômenos, onde é possível encontrar o "agrupamento de ideias, que constrói, a partir de muitos lados, o capital cultural da humanidade" (CHILDE, 1937, p. 4). Tempos depois, a ideia de Childe seria reformulada por Alfred Kroeber, o qual defende, no artigo Stimulus diffusion uma "difusão estimulada". Para ele, o que ocorre principalmente é a difusão da ideia ao invés do artefato, isto é, Kroeber cita o modo como a importação de produtos chineses de porcelana para a Europa levaram os europeus a procurarem sistematicamente os materiais necessários e quais os procedimentos para replicar o processo e produzir a cerâmica no Velho Continente (KROEBER, 1940, p. 2). Entendemos que ambos processos habitam as páginas de Os Prolegômenos.
} 
As repetições apresentadas pelas civilizações em sua dança de ascensão e declínio despontam da mesma forma em diferentes autores. Além disso, toda civilização ou povo carrega em si sua cultura material e imaterial, as quais, por sua vez, são atravessadas por idiossincrasias, regionalismos e peculiares formas de pensar. Como não há homogeneidade, tudo aquilo que parece nos separar, "inclusive as fronteiras das nações, são, ao mesmo tempo, não só barreiras, mas também lugares de comunicação e de intercâmbio" (REIS, 1999, p. 85).

Sobre isso, o antropólogo norte-americano Ralph Linton escreveu um belíssimo texto que acreditamos resumir bem parte do que defendemos aqui. Diz ele (LINTON, 1959, p. 355-356):

O cidadão norte-americano desperta num leito construído segundo padrão originário do Oriente Próximo, mas modificado na Europa Setentrional, antes de ser transmitido à América. Sai debaixo de cobertas feitas de algodão cuja planta se tornou doméstica na Índia; ou de linho ou de lã de carneiro, um e outro domesticados no Oriente Próximo; ou de seda, cujo emprego foi descoberto na China. Todos estes materiais foram fiados e tecidos por processos inventados no Oriente Próximo. Ao levantar da cama faz uso dos "mocassins" que foram inventados pelos índios das florestas do Leste dos Estados Unidos e entra no quarto de banho cujos aparelhos são uma mistura de invenções europeias e norte-americanas, maias e outras recentes. Tira o pijama, que é vestiário inventado na Índia e lava-se com sabão que foi inventado pelos antigos gauleses, faz a barba que é um rito masoquístico que parece provir dos sumerianos ou do antigo Egito.

Voltando ao quarto, o cidadão toma as roupas que estão sobre uma cadeira do tipo europeu meridional e veste-se. As peças de seu vestuário têm a forma das vestes de pele originais dos nômades das estepes asiáticas; seus sapatos são feitos de peles curtidas por um processo inventado no antigo Egito e cortadas segundo um padrão proveniente das civilizações clássicas do Mediterrâneo; a tira de pano de cores vivas que amarra ao pescoço é sobrevivência dos xales usados aos ombros pelos croatas do século XVII. Antes de ir tomar o seu breakfast, ele olha a rua através da vidraça feita de vidro inventado no Egito; e, se estiver chovendo, calça galochas de borracha descoberta pelos índios da América Central e toma um guarda-chuva inventado no sudoeste da Ásia. Seu chapéu é feito de feltro, material inventado nas estepes asiáticas. De caminho para o breakfast, pára para comprar um jornal, pagando-o com moedas, invenção da Líbia antiga. No restaurante, toda uma série de elementos tomados de empréstimo o espera. $\mathrm{O}$ prato é feito de uma espécie de cerâmica inventada na China. A faca é de aço, liga feita pela primeira vez na Índia do Sul; o garfo é inventado na Itália medieval; a colher vem de um original romano. Começa o seu breakfast com uma laranja vinda do Mediterrâneo Oriental, melão da Pérsia, ou talvez uma fatia de melancia africana. Toma café, planta abissínia, com nata e açúcar. A domesticação do gado bovino e a ideia de aproveitar o seu leite são originárias do Oriente Próximo, ao passo que o açúcar foi feito pela primeira vez na Índia. Depois das frutas e do café vêm waffles, os quais são bolinhos 
fabricados segundo uma técnica escandinava, empregando como matériaprima o trigo, que se tornou planta doméstica na Ásia Menor. Rega-se com xarope de maple, inventado pelos índios das florestas do Leste dos Estados Unidos. Como prato adicional talvez coma o ovo de uma espécie de ave domesticada na Indochina ou delgadas fatias de carne de um animal domesticado na Ásia Oriental, salgada e defumada por um processo desenvolvido no Norte da Europa. Acabando de comer, nosso amigo se recosta para fumar, hábito implantado pelos índios americanos e que consome uma planta originária do Brasil; fuma cachimbo, que procede dos índios da Virgínia, ou cigarro, proveniente do México. Se for fumante valente, pode ser que fume mesmo um charuto, transmitido à América do Norte pelas Antilhas, por intermédio da Espanha. Enquanto fuma, lê notícias do dia, impressas em caracteres inventados pelos antigos semitas, em material inventado na China e por um processo inventado na Alemanha. Ao inteirar-se das narrativas dos problemas estrangeiros, se for bom cidadão conservador, agradecerá a uma divindade hebraica, numa língua indoeuropeia, o fato de ser cem por cento americano.

Essas contínuas interseções ocorrem de entre diferentes povos e até dentro da mesma nação. Na Itália, por exemplo, até hoje há certa divisão cultural que separa o norte do sul. Na Alemanha, os habitantes da região da Baviera diferem dos alemães do norte em aspectos como dialeto, religião e política. Na ilha do mar do norte chamada Reino Unido temos idiomas como o galês, o gaélico, o Ulster Scot (dialeto da região de Ulster) além de uma língua inglesa recheada de sotaques e gírias como o cockney, o bristolian, o mancunian, o scouse, o brummie e o suffolk, entre outros. Já na Espanha, há, até nossos dias, enormes diferenças entre catalães, bascos, andaluzes e madrilenos. Ao mesmo tempo, porém, há ideias que trespassam esses e outros povos. Muitas delas são equivocamente entendidas como algo puramente europeu, mas ao percorrermos o árduo caminho de sua genealogia percebemos, muita vez, que elas são construções transnacionais, desenvolvidas principalmente nas veias por onde corre o sangue do comércio e no contínuo movimento ampliação e contrição dos grandes polos de poder.

A lex mercatoria, por exemplo, é um desses fenômenos que indica não só a expansão do comércio marítimo internacional, majoritariamente feito por cabotagem $\left(\right.$ NIANE, 2011, p. 744) ${ }^{6}$, durante o período no qual viveu Ibn Khaldun - séculos XIV e XV -, como também a capacidade da duração e a força de ampliação de um mecanismo transmissor de ideias. Ainda hoje temos algo que remete à lex mercatoria presente no comércio internacional $^{7}$. Esse código, que para muitos surgiu quando o árabes

\footnotetext{
${ }^{6}$ Obviamente, Niane não se refere aqui ao conceito moderno de cabotagem, ou seja, navegação entre portos de um mesmo país, mas sim à navegação que é feita sem perder a costa de vista.

${ }^{7}$ Para alguns historiadores a lex mercatoria existente atualmente teria surgido a partir do ius gentium romano, lei que regulava as relações econômicas entre os estrangeiros e os cidadãos romanos; outros,
} 
dominavam o Mediterrâneo (PEREIRA, 2002, p. 286), foi amplamente utilizado pelos comerciantes italianos medievais e posteriormente por ingleses e holandeses. Resultado direto do intercâmbio de regras e costumes, a lex mercatoria e seus subprodutos ou símiles dominavam as negociações em cidades como Túnis, Sevilha, Alexandria e Cairo, onde Ibn Khaldun viveu ${ }^{8}$.

Outro exemplo do comércio como mecanismo de transmissão de ideias é o papel da Rota da Seda na propagação do budismo Mahayana pela China, regiões da Ásia Central e até mesmo a parte leste do Mediterrâneo (HOWARD, 2012, p. 229). Essa expansão acabaria criando, como séculos mais tarde ocorreria com Meca e outras cidades muçulmanas, rotas de peregrinação que levariam milhares de pessoas a locais sagrados na China, Índia e Nepal.

O mesmo pode ser dito do commendam, espécie de contrato de origem árabe que serviu para neutralizar a questão da usura no comércio durante o período que vai aproximadamente do século X ao século XV. Esse mesmo mecanismo, que formalizava uma parceria comercial, serviu também para diminuir os riscos, o que, por sua vez, viabilizou atingir escala comercial. O commendam foi o primeiro passo no desenvolvimento da corporação moderna. Com ele era possível que várias pessoas investissem dinheiro em uma mesma empreitada comercial (LOWRY, 2003, p. 15).

Outro pensador que ecoa em Os Prolegômenos é Xenofonte, que na obra Memoráveis (IV, 4, 19-20) trata das leis escritas e não escritas presentes em inúmeras sociedades. Em Memoráveis, o diálogo leva o leitor a concluir que mesmo tais leis, que ele acredita terem sido criadas por Deus, são transgredidas. Essa mesma questão está

como Clive Maximilian Schmitthoff, vão mais longe no tempo e apontam que as origens da lex mercatoria estariam no Egito Antigo e nas práticas de comércio marítimo grego e fenício da Antiguidade. Há também aqueles, como Luiz Cézar Ramos Pereira, que acreditam que tal lei seja uma invenção árabe. Independentemente de qual seja sua origem, o exemplo serve para indicar como essa importante regulamentação comercial esteve presente em inúmeras cidades de povos distintos, o que, por sua vez, reforça a noção de que muitas das ideias contidas nessa lei tenham se espalhado pelo Mediterrâneo e pelas civilizações que dominaram essa região do mundo.

${ }^{8}$ Segundo Trakman, "o ambiente europeu medieval era, de muitas maneiras, idealmente adequado para a universalização da prática comercial em um sistema uniforme de direito comercial. A Europa foi geograficamente traçada para tal. Os comerciantes podiam atravessar facilmente vastas áreas do Mar Mediterrâneo em direção a mercados e feiras bem estabelecidas, onde os comerciantes da Europa e do Norte da África se reuniram para negociar seus produtos" (TRAKMAN, 1983, p. 9, tradução nossa). Portanto, como Ibn Khaldun era um profundo conhecedor da jurisprudência da época, sua obra de maneira quase que automática aponta inevitavelmente para a enorme importância do comércio como motor da prosperidade econômica de uma sociedade. Assim, ele amplia em seu texto o eco desses entendimentos comerciais medievais. Certamente, o autor de Os Prolegômenos esteve em contato e sabia da importância do respeito a mecanismos de viés profundamente cosmopolita como a lex mercatoria. 
presente no texto de Ibn Khaldun, que também coloca a transgressão das leis divinas entre os principais motivos da derrocada de sociedades muçulmanas. Aliás, o autor de Os Prolegômenos é enfático ao afirmar que todas as leis "se fundamentam sobre a necessidade da conservação da Sociedade" (KHALDUN, 1958, p. 96), o que demonstra a força de determinadas ideias, que se espalham ou ressurgem em razão de sua forte vinculação com a realidade, como se fossem o resultado de uma "convergência adaptativa" conceitual capaz de produzir soluções semelhantes para temas semelhantes.

Apesar dessas similitudes, há um inegável desconhecimento da genealogia de muitos conceitos presentes em Os Prolegômenos. Em parte, isso ocorre em razão da imensa dificuldade de reconstrução da jornada dessas ideias. É trabalho árduo reconstruir, mesmo que parcialmente, o caminho do conhecimento quando esse passa de um idioma para outro. Isso porque, muita vez, tal transmissão, produzida em grande parte pelos trabalhos de tradução, se comporta como uma doença infecciosa (O’LEARY, 1979, p. 4).

No caso da doença, os epidemiologistas buscam sempre responder às seguintes perguntas: “qual é sua origem?” e "como ela chegou até aqui?". Quanto às traduções, o trabalho do filólogo é, até certo ponto, semelhante.

O problema, no último caso, é o seguinte: apesar de o conhecimento, assim como a doença infecciosa, não reconhecer fronteiras e ser resultado de um processo construtivo cumulativo, torna difícil chegar ao texto fundador, ou seja, ao paciente zero - isto é, à primeira mente "infectada" por aquela ideia. Em função dessa dificuldade, o percurso das traduções é cheio de lacunas, algumas das quais instransponíveis. Nesse caso, o que resta àquele que se dedica à filologia ou à reconstrução da história de determinadas ideias é compreender a mecânica por trás da construção de tal conhecimento e assim produzir teses a partir das regras mais gerais de funcionamento dessas engrenagens conceituais.

Quando surge uma língua, tal nascimento ocorre sempre sobre os ombros de uma linguagem que lhe é anterior e da qual são inescapavelmente retirados alguns conceitos. A história do conhecimento humano se dá sobre esse mesmo mecanismo. É dele que algumas ideias extraem sua flexibilidade, adquirindo variações culturais que acabam por distingui-las entre si. No período que vai dos século IX ao século XIV,

\footnotetext{
${ }^{9}$ Nome dado, em biologia, às adaptações de espécies diferentes que habitam um mesmo ambiente.
} 
muitas ideias presentes no mundo grego chegaram aos textos árabes, ganharam certo sotaque ou foram totalmente reformuladas para depois seguir adiante.

O mesmo ocorreu quando os fenícios ${ }^{10}$ chegaram, vindos do Golfo Pérsico, por volta de 3.000 a.C., ao litoral do Mediterrâneo (GOMBRICH, 2008, p. 30). Esse povo foi responsável por boa parte da divulgação do conhecimento então existente ${ }^{11}$. Não é por acaso que o alfabeto fenício, que está na gênese de muitos outros alfabetos (GIODARNI, 1969, p. 181), acabou adotado pelos gregos, tornando-se assim o mais antigo ancestral do grego clássico. Caso contrário, como pode uma língua que deriva as letras de seu alfabeto - alpha, beta, gamma, delta - das do alfabeto fenício - aleph, beth, gimel, daleth - (STÖRIG, 1990, p. 68) ser entendida como um produto exclusivo da cultura ocidental?

Da mesma forma que a lex mercatoria, o commendam e o alfabeto fenício, Aristóteles, com seu racionalismo observador do mundo, das sociedades e das pessoas, teve alguns de seus textos, séculos depois, deglutidos pela civilização muçulmana nos primeiros séculos do califado abássida, o qual durou de 749 a 1258. Em sua versão em língua árabe, algumas ideias aristotélicas, foram transformadas e atingiram o auge em obras de pensadores como Al-Fārāāi, Avicena, Averróis e Ibn Khaldun ${ }^{12}$.

\footnotetext{
${ }^{10}$ Muitos historiadores se referem aos fenícios como cananeus (ou canaanitas), povo dos quais eles descendiam. Segundo o historiador, Jonathan N. Tubb, autor do clássico Canaanites, os cananeus possuíam um alfabeto, dominavam metalurgia e faziam comércio com Egito e Mesopotâmia (TUBB, 1998, p. 33). Já os fenícios eram chamados pelos gregos "phoinikes" em referência às cores dos tecidos vermelhos e púrpuras utilizados e comercializados pelos descendentes do cananeus. No entanto, os próprios fenícios não se autoproclamavam fenícios. Eles eram cidadãos de cidades muradas com grandes portos como Biblos, Sidon e Tiro. Essa civilização surgiu por volta do ano 3.000 a.C., na região do Levante, onde hoje ficam Líbano, Síria e Israel, e atingiu seu apogeu entre os séculos X e VI a.C, período no qual eles dominaram o comércio no Mediterrâneo. Em: Phoenicia. Encyclopædia Britannica: Encyclopædia Britannica Ultimate Reference Suite. Chicago: Encyclopædia Britannica. 2011

${ }^{11}$ Os fenícios foram notáveis comerciantes e ajudaram a colonizar boa parte dos países do Mediterrâneo no período que vai desde 3.000 a.C. até o primeiro milênio antes de Cristo. $\mathrm{Na}$ antiga cidade de Biblos, que ficava aproximadamente 30 quilômetros ao norte de onde hoje é Beirute, a capital libanesa, há registros de comércio com a civilização egípcia desde a quarta dinastia, entre aproximadamente 2613 e 2494 a.C. Em: Phoenicia. Encyclopædia Britannica: Encyclopædia Britannica Ultimate Reference Suite. Chicago: Encyclopædia Britannica. 2011

${ }^{12}$ Quando nos referimos aqui a certo "racionalismo aristotelismo", apontamos para o fenômeno da chegada do trabalho de Aristóteles, ou parte dele, aos pensadores árabes, como é o caso de Ibn Khaldun. É sabido, no entanto, que alguns textos que foram atribuídos pelos árabes ao Estagirita, como a Teologia de Aristóteles ou a obra dele sobre política, à qual Ibn Khaldum se refere em Os Prolegômenos, não eram de sua lavra. Mesmo assim, não é possível negar a forte presença de mecanismos conceituais como a lógica aristotélica em muitos textos árabes. No caso de Os Prolegômenos, há inúmeras citações ao pensamento e à figura de Aristóteles, o qual, para Ibn Khaldun, teria sido, "de todos os filósofos (...), o mais profundo e de maior fama" (KHALDUN, 1960, p. 127-128). O autor de Os Prolegômenos chega inclusive a afirmar que as ideias de Aristóteles foram de tal maneira estudadas pelos pensadores árabes que estes "se acharam em condições de refutar grande número de opiniões emitidas pelo Primeiro MESTRE Aristóteles. Foi às doutrinas deste que se apegaram particularmente, quer para refutá-las, quer
} 
Portanto, é possível dizer que igualmente à lida com o comércio, ensinada e praticada desde os cananeus e fenícios até os muçulmanos e europeus, o método silogístico aristotélico, espécie de conhecimento-ferramenta, se espalhou da mesma forma por várias civilizações. Esse fenômeno é recorrente na história do conhecimento. Ele ocorreu com a invenção e utilização da roda na Eurásia da pré-história; com o surgimento e a posterior abrangência da lei romana; e com soluções arquitetônicas como o arco quebrado das catedrais góticas, o qual, por sua vez, foi inspirado no arco ogival muçulmano, que surgiu no Egito e entrou na Europa via Sicília (JACKSON, 1915, p. 256).

Da mesma maneira que uma invenção é um amalgama de ideias que a antecederam, um conhecimento em particular está permeado de pedaços ou da totalidade de conceitos preexistentes. Foi isso o que ocorreu na passagem do saber em grego para o árabe. Segundo o historiador De Lacy Evans O'Leary (1979, p. 4, tradução nossa),

\begin{abstract}
Quando os árabes herdaram a cultura da Grécia Antiga, o pensamento grego estava interessado principalmente em ciência. Atenas foi substituída por Alexandria e o helenismo foi inteiramente 'modernizado'. Essa era uma atitude à qual os estudiosos de Alexandria estavam diretamente conectados, porém, isso não era de maneira alguma algo confinado àquela cidade. Esse foi o resultado lógico da influência de Aristóteles, o qual era, antes de tudo, um cuidadoso e paciente observador da natureza. Aristóteles também foi, em razão desse comportamento, o criador da ciência moderna, a qual, por sua vez, tem sua gênese em pensamentos mais antigos, nas especulações dos primeiros filósofos a respeito da origem do mundo e seus habitantes. Porém, foi Aristóteles quem introduziu o que seria conhecido como método científico.
\end{abstract}

Em razão disso, o racionalismo grego e o silogismo de fundo aristotélico presentes em textos árabes, latinos e siríacos são monumentos conceituais que se opõem à divisão do mundo do conhecimento entre regiões como Ocidente e Oriente. "Os filósofos muçulmanos (...) fundamentaram sua filosofia nas ciências físicas de Aristóteles" (AL-JABRI, 1999, p.157). Sua propagação é uma prova de que a chegada e a difusão do saber grego dentro do Império Abássida em áreas como filosofia, medicina, astronomia, agricultura, geografia, comércio, linguagem e matemática. Ela é um

para sustenta-las" (KHALDUN, 1960, p. 129). Portanto, há uma profunda vinculação à figura de Aristóteles, mesmo quando esta, no caso de obras que não foram escritas por ele, seja apenas uma "figura literária" muito semelhante, por exemplo, ao caso do Avicena latino. O próprio tradutor da obra para o português, José Khoury, explica na nota número 9 na página 98 do primeiro tomo de Os Prolegômenos que quando Ibn Khaldun faz referência à Política ou às Econômicas de Aristóteles ele está, na verdade, se referindo a "alguma obra apócrifa, como existiam tantas entre as dos autores árabes, aceitas como traduções de escritos deixados pelos Gregos". 
capítulo importante de um longo processo global de intercâmbios, os quais ocorrem mesmo em casos de encontros violentos entre colonizados e colonizadores ou dominadores e dominados (SIVASUNDARAM, 2013, p. 243-244).

O conhecimento, em função dessas relações, é o produto de um interminável fluxo de continuidade histórica marcado por feitos cumulativos, apesar dos inúmeros e inegáveis recomeços e ruínas desse transcurso. Essa corrente de eventos resulta em um processo de aglutinação e aprendizado de âmbito mundial (RENN, 2012, p. 27). É isso que ocorre quando lemos sobre certa influência de certo aristotelismo de viés árabe nos domínios espanhóis no continente americano durante os séculos VX e XVI (GRUZINSKI, 2004, p. 369) ${ }^{13}$.

O fato de Ibn Khaldun ter vivido em locais de intenso comércio, pujante vida urbana e de ter sido um importante jurista e diplomata ajudou a colocá-lo em contato com os trabalhos intelectuais mais sofisticados de sua época. Foi assim, pela estrada do comércio, da vida urbana, da diplomacia, do direito e da conquista que muitas ideias chegaram às páginas de Os Prolegômenos. Depois, por essas mesmas vias, tais ideias, retrabalhadas pela mente do pensador tunisiano, se espalharam, alcançando historiadores otomanos ${ }^{14}$ do século XVII, como Katib Çelebi (BOWERING, 2013, p. XIII), Ahmed Ibn Lutfullah, também conhecido por Münejjimbashi (LEWIS, 1993, p. 235) e Mustafa Na'ima (MOLINS, 2006, p. 376).

\footnotetext{
${ }^{13}$ Gruzinski afirma que o historiador Diego Muños de Camargo (1529-1599), um filho de espanhol e uma índia tlaxcala, utilizou ideias arabizadas de Aristóteles, Platão e Ptolomeu em suas crônicas mestiças Relaciones geográficas; Descripción de la ciudad y provincia de Tlaxcala; Suma y epiloga de toda la descripción de Tlaxcala; e História de Tlaxcala. Portanto, tais textos, produzidos no século XVI, no México, tinham forte influência dos franciscanos e, por consequência, a presença de um certo racionalismo aristotélico de fundo árabe. Assim, tal racionalismo surgido na Antiguidade, depois de atravessar o mundo islâmico e ser por ele ser transformado, chega à Europa e finalmente estende seus tentáculos até o continente americano. Nesse sentido, é possível dizer que certa maneira de pensar baseada em textos filosóficos, apesar dos temperos e das nuances que cada região as concedeu, transnacionalizou-se completamente junto com as caravelas e as rotas comerciais.

${ }^{14}$ Bernard Lewis, em texto escrito para a coletânea Ibn Khaldun: the Mediterranean in the 14th century: rise and fall of empires, feita sob a coordenação da professora María Jesús Viguera Molins, aponta que o interesse dos historiadores otomanos pela obra Os Prolegômenos resultou, em boa parte, das conquistas do império turco no Egito e na Síria. Para Lewis, essa conquista produziu interesse na intelectualidade turca, a qual pretendia saber mais sobre os novos territórios, principalmente o Egito. Em razão disso, os historiadores turcos do século XVII acabaram se aproximando dos textos de Ibn Khaldun. Depois, também segundo Lewis, por razões não muito diferentes, o mesmo texto foi alvo de estudos de intelectuais europeus como Silvestre de Sacy, em seu Chresthomatie arabe, em 1806, e Joseph von Hammer, o qual, se refere a Ibn Khaldun como o "Montesquieu árabe" em seu Geschichte des osmanischen Reiches, obra de 10 volumes produzida entre os anos de 1827 e 1835 (MOLINS coord., 2006, p. 376-379).
} 
$\mathrm{Na}$ tentativa de demonstrar como e a partir do que se construiu essa arquitetura conceitual e qual foi sua importância histórica, o trabalho aqui apresentado analisará excertos do texto de Os Prolegômenos de Ibn Khaldun, principalmente os que fazem referências à área de economia e às questões ligadas à valoração do trabalho, ao comércio, ao conceito de asabiyyah ${ }^{15}$, ao papel da oferta e da demanda na manutenção social e à importância dessas ideias na formação da cosmovisão presente no texto e do modelo de poder que ele propõe.

No Capítulo I apresentaremos um panorama do período no qual Ibn Khaldun viveu e como esse ambiente ajudou a formar seu pensamento e obra por ele produzida. Nesse trecho também será apresentada uma biografia de Ibn Khaldun, pois acreditamos que a “'historicização' é indispensável não apenas para adquirir uma compreensão história do pensamento estudado" (AL-JABRI, 1999, p. 58) como para "fixar o eixo de pensamento do autor ao redor de uma problemática manifesta” (AL-JABRI, 1999, p. $58)$.

Em seguida será feita uma análise da materialidade da obra em si: como ela está organizada, quais pontos e assuntos trata, como ela chegou até nós, quais são as principais diferenças entre as várias traduções existentes e porque tal obra nos oferece um olhar tão pessimista da história. Para tal, apresentaremos também uma breve análise de cada tomo. Portanto, os três tomos que formam o texto de Os Prolegômenos de Ibn Khaldun serão analisados mais rapidamente em sua totalidade. Na sequência, o texto tratará com maior atenção os trechos onde a obra trata de questões de fundo econômico, principalmente a questão crucial para esse trabalho: a teoria de Ibn Khaldun sobre a relação entre valor e trabalho, o funcionamento do comércio e a cosmovisão que surge a partir dessas análises.

Portanto, no segundo capítulo, buscaremos apontar o que pensamos estar no plano de fundo da visão que Ibn Khaldun tinha do trabalho e do papel desse mecanismo dentro das sociedades. Nesse ponto, sugeriremos algumas possíveis razões para o

\footnotetext{
${ }^{15}$ Segundo Ibn Khaldun, asabiyyah é a coesão existente entre membros de uma mesma tribo ou de um determinado grupo social. Porém, é importante adiantar que, para o autor de Os Prolegômenos, asabiyyah não é algo eterno, ou seja, não é possível perpetuá-la. Logo, em razão de tal efemeridade, essa coesão tende a perder a força quando um grupo altamente dotado de asabiyyah chega ao poder. Assim, quanto maior for a presença da asabiyyah em determinado grupo, maior será a chance desse grupo se tornar uma poderosa dinastia. No entanto, em razão de tal conquista, a qual inexoravelmente vai distanciar tais indivíduos da vida nômade (badawi), esse mesmo sentimento de asabiyyah automaticamente irá relaxar entre os membros desse mesmo grupo, gerando assim um ciclo de aquisição e perda de poder.
} 
surgimento de uma compreensão do funcionamento das sociedade tão marcadamente vinculada à experiência direta e à observação racional e pragmática da realidade.

$\mathrm{Na}$ Conclusão, avaliaremos os resultados dessa análise e indicaremos quais foram os possíveis caminhos traçados pelas ideias que desembocaram no texto de Ibn Khaldun, de onde talvez elas vieram e para onde possivelmente proliferaram. Também analisaremos quais motivos levaram seu trabalho a cair naquilo que Alain de Libera chama de "herança esquecida"16.

Por último, é importante apontar que o recolhimento e a análise das ideias econômicas dispersas pelo gigantesco Os Prolegômenos de Ibn Khaldun corresponde à maior e principal parte do trabalho aqui apresentado. Sem esse levantamento ${ }^{17}$, essencial para a compreensão da cosmovisão presente nos escritos de Ibn Khaldun e para um entendimento global dos mesmos, não seria factível alcançar as conclusões às quais chegamos e muito menos vislumbrar possíveis estudos a serem feitos no futuro.

\footnotetext{
${ }^{16}$ Em sua obra Pensar na Idade Média, o intelectual francês, Alain de Libera, afirma que "a transmissão e o desenvolvimento da filosofia e da ciência gregas façam parte ou não da identidade histórico-cultural do mundo árabo-muçulmano, é algo que se pode discutir e que compete aos interessados resolver, se o quiserem, de modo diferente dos historiadores. Mas que os 'árabes' tenham desempenhado um papel determinante na formação da identidade intelectual da Europa é algo que não é possível 'discutir', a não ser negando a evidência. A simples probidade intelectual exige que a relação do Ocidente com a nação árabe passe também hoje pelo reconhecimento de uma herança esquecida" (LIBERA, 1999, p. 102).

${ }^{17} \mathrm{O}$ levantamento dos conceitos econômicos desse trabalho se deu a partir de uma obra que ainda não possui um vocabulário padronizado, o que gera enormes diferenças entre as traduções e o texto árabe. Além disso, Ibn Khaldun, muita vez, desloca as palavras de seu uso. Não são poucas as ocorrências de termos que recebem um significado técnico mais limitado ou daquelas palavras que simplesmente foram criadas pelo autor (CHEDADDI, 2005, p. 135). Exemplos desse deslocamento incluem os conceitos Umrān badawi (sociedade, cultura ou vida nômade), Umrān hadari (sociedade, cultura ou vida sedentária ou urbana), asabiyya (solidariedade, espirito de grupo, solidariedade tribal e poder social) e rizc (benefício, provisão, subsistência), entre tantos outros. Para os casos mais centrais foi feita uma pesquisa filológica, ou seja, foram analisados como alguns termos árabes aparecem nas traduções, porém, no geral, esse trabalho filológico deu lugar à análise mais geral das ideias econômicas e da cosmovisão presentes no texto, além de sua importância na história do pensamento, as quais nos propomos estudar com mais profundidade.
} 


\section{CAPÍTULO 1}

São os homens que estão sujeitos aos eventos fortuitos, e não os eventos fortuitos aos homens (HERÔDOTOS, 1985, p. 356)

\subsection{PANORAMA HISTÓRICO}

O mundo no qual viveu o autor de Os Prolegômenos foi palco de terríveis epidemias, conflitos constantes, instabilidade política, crise econômica e declínio da civilização árabe, a qual, até então, havia dominado inúmeras regiões do planeta, inclusive parte da Europa. O magnum opus de Ibn Khaldun reverbera o instante histórico do século XIV, onde o poder se mostra transitório, mudando gradativamente de mãos e tornando regiões centrais em periféricas e vice-versa. Nesse período, enquanto boa parte da intelectualidade árabe trocava al-Andaluz pelo norte da África, segundo Otto Maria Carpeaux (2011, p. 243), o século XIV manteve-se uma

(...) época de intenso comércio internacional. As fazendas flamengas chegaram, através de Luebeck, ao Báltico; as florentinas, até o Oriente. A indústria têxtil de Florença empregava lã inglesa e borgonhesa. A indústria têxtil de Flandres comprava lã na Inglaterra, o potássio em Dantzig, as tintas na Índia, através do Egito e Veneza.

A dura realidade do século XIV atingiu o autor de Os Prolegômenos desde sua infância, pois, quando Ibn Khaldun era uma criança, o mundo sofria com epidemias de fome. Na China, região onde mais tarde surgiria a Peste Negra, cerca de quatro milhões de pessoas morreram vítimas da fome na região de Kiang em uma epidemia que possivelmente começou no início da década de 1330 e durou até 1337 (HECKER, 1844, p. 12). Nesse mesmo período, o planeta Terra era palco de uma série de eventos catastróficos que teve início praticamente no mesmo ano em que Ibn Khaldun nasceu: 1332. Depois, em 1333, uma seca se abateu sobre a região dos rios Kiang e Hoai, na China. Em seguida, chuvas torrenciais atingiram Kingsai, então capital do império chinês, matando cerca de 400 mil pessoas. Em 1338, Kingsai seria atingida por vários terremotos durante mais de uma semana (HECKER, 1844, p. 12). No mesmo período, esse quadro de seca, inundações, fome e terremotos atingiria também parte da Europa. 
Em 1333, que os livros de história da Catalunha chamam de "lo mal any primer" (o primeiro ano ruim), a região foi tomada pela fome. Nos anos seguintes, a peste e a subnutrição reduziu a população de Barcelona de 50 mil habitantes na década de 1340 para menos de 20 mil em 1477. No geral, a atual região da Catalunha, que então fazia parte do reino de Aragão, viu sua população cair de 500 mil habitantes em 1340 para cerca de 250 mil em 1497 (NÚÑES; TORTELLA, 2003, p. 115). Esse cenário de destruição e fome era ideal para peste negra, a pestilência que atingiu praticamente todo o mundo conhecido por Ibn Khaldun.

Em razão disso, a crise que atravessou a vida do autor de Os Prolegômenos foi, em boa parte, resultado da peste negra, doença que matou cerca de 50 milhões de pessoas no século XIV segundo a Organização Mundial da Saúde (OMS. Fact Shet, set. 2016). Fruto do crescimento do comércio e da primeira guerra bacteriológica da história, o grande surto inicial dessa epidemia ocorreu na China, na província de Hubei, em 1334. Possivelmente, a doença foi trazida do deserto de Gobi, na Mongólia, onde teria surgido, para esse centro urbano pelas caravanas de mercadores (GOTTFRIED, 1983, p.35).

Ela atingiu os europeus e os povos do norte da África pouco tempo após um exército Kipchak, do Império Mongol, utilizar catapultas para jogar cadáveres carcomidos pela doença contra um posto comercial genovês na costa do mar Negro durante um cerco (BRODY; BRODY, 1999, p. 30). O enclave genovês, situado desde 1266 na cidade de Caffa (Capha, Kaffa ou Kefe; hoje, Feodosiya, na Ucrânia), no mar Negro, foi cercado em 1346 pelas forças de Jani Beg, o khan mongol comandante da Horda de Ouro. Seu exército, que tinha o apoio dos venezianos, os quais competiam comercial e militarmente com os genoveses, acabaria atingido pela peste. Durante o cerco, os soldados comandados por Jani Beg começaram a morrer em números assustadores, todos vítimas da peste negra. A devastação foi tão grande que o líder mongol acabaria desistindo do cerco. Porém, em um último ato, ele decidiu jogar os corpos dos soldados mortos pela praga dentro do enclave genovês. Rapidamente os sobreviventes italianos jogaram esses corpos ao mar e fugiram em quatro navios pensando que seria possível assim escapar da peste. Mal sabiam eles que estavam levando consigo a doença que devastaria boa parte da Europa (GEOFFREY, 1971, p. 1$5,29,45-49)$. 
Poucas semanas após chegar ao portos de Gênova e Veneza vinda dessa região na Crimeia, a peste negra estava matando cerca de 600 venezianos por dia. Ao final, a cidade que ajudou Jani Beg no cerco à Caffa viu seus canais ficarem tomados pelos "corpi morti" e perdeu três quintos de sua população. Entre os genoveses a epidemia não chegou a ser tão devastadora, apesar de também ter deixado milhares de mortos (NORWICH, 1989, p. 215).

A partir de Veneza e Gênova, a bactéria Yersinia pestis, causadora da peste bubônica, se espalhou até atingir a Sicília, onde chegou em meados do segundo semestre de 1347, para, em seguida, alcançar Túnis, em abril de 1348. A velocidade de transmissão resultou da substancial relação comercial que as duas cidades mantinham paradoxalmente, a mesma rota por onde muitas ideias se espalharam pela Europa e Norte da África serviu, nesse caso, para praticamente destruir ambas regiões ${ }^{18}$. Em pouquíssimo tempo, cidades onde hoje ficam Argélia e Marrocos estavam tomadas pela epidemia (BENEDICTOW, 2004, p. 65-66).

Em Túnis, provavelmente a maior cidade do norte da África naquele momento, a peste chegou a matar cerca de mil pessoas por dia. Em pouquíssimo tempo, praticamente todo o mundo islâmico havia sido tomado pela epidemia. As estimativas do número total de mortos variam entre um terço da população geral e até $50 \%$ dos habitantes das grandes cidades muçulmanas (GOTTFRIED, 1983, p. 41).

A praga, que em 1349 atingiu o Egito (GARCIN, 2010, p. 435), chegou praticamente ao mesmo tempo em outras regiões como Toscana, Provença, Bordeaux, Paris e Londres. O número de mortos na Europa, África e Ásia era algo que não tinha precedentes. Esse ciclo de horror e pestilência bubônica devastou cidades inteiras. O ímpeto dessa onda epidêmica só diminuiria anos mais tarde, "em 1352 nas estepes da Rússia central” (LE GOFF; SCHMITT, 2002, V. 1, p. 461).

A magna pestilencia, como os textos latinos se referiam ao flagelo, foi terrível não só para Ibn Khaldun, que perdeu pai, mãe e todos seus mestres da infância e adolescência. Ela foi economicamente destrutiva para praticamente todo norte da África em razão do "declínio da população rural e seu gado", da drástica redução na "produção agrícola" e dos "recursos arrecadados pelo governo com impostos" (HOURANI, 2001,

\footnotetext{
${ }^{18}$ No nosso caso, a devastadora propagação desse flagelo serve também para mapear a amplitude da rede comercial do século XIV, fator muito presente nas teses defendidas por Ibn Khaldun em Os Prolegômenos.
} 
p. 221). A situação era tão inaudita que no Cairo, a produção agrícola do período entre 1348 e 1349 foi isenta de taxação para não desaparecer, já que a cidade chegou a perder 7.000 habitantes diariamente para a praga (GOTTFRIED, 1983, p. 35).

Além de Ibn Khaldun, outros historiadores da época descreveram a devastação como algo que havia colocado o mundo de cabeça pra baixo. Segundo o egípcio AlMaqrizi (1364-1442), 1348 "foi um ano onde tudo morreu, inclusive o próprio ano de 1348” (FROMHERZ, 2010, p. 51).

Social e politicamente a praga também foi devastadora, pois praticamente reduziu a pó o status quo das regiões afetadas em função da morte de milhares de pessoas responsáveis por questões legais e administrativas. Em razão dos altíssimos números de mortos, a ordem legal então estabelecida deu lugar ao caos. A praga foi tão poderosa que alterou até mesmo a lei islâmica. Impactado pelos milhares de mortos por dia, o sistema de aplicações para dividir as heranças simplesmente entrou em colapso em muitas cidades. Esse ponto central da sharia acabaria sendo adaptado (ou até mesmo abolido) em razão das condições daquele período (FROMHERZ, 2010, p. 51-52).

Segundo Edwin Hunt e James Murray (1999, p. 154), os altos índices de mortalidade produzido pela peste negra transformou associações comerciais de longo prazo, os commendam, em investimentos muito arriscados, especialmente porque nesse momento os herdeiros daqueles que anteriormente teriam fechado acordos estavam mais interessados em gastar sua herança para sobreviver do que em perpetuar negócios ou parcerias comerciais.

Em função desse quadro, sociedades comerciais formadas por vários agentes "tornaram-se cada vez mais arriscadas, exigindo a atenção próxima e dedicada dos proprietários-gerentes" (HUNT; MURRAY, 1999, p. 155), com isso, o número de contratos de commendam reduziu drasticamente.

Para piorar o quadro, o mundo muçulmano enfrentava um novo equilíbrio comercial em razão do desenvolvimento e do aumento na eficiência da produção têxtil de nações europeias, as quais também passaram a ter um papel cada vez mais relevante na navegação no Mediterrâneo (HOURANI, 2001, p. 221).

Apesar desse avanço produtivo na Europa, a peste negra encerrou um ciclo econômico de prosperidade na região, deixando em seu lugar inúmeras revoltas 
populares, aumento nos custos da mão de obra e escassez de produtos (BRODY; BRODY, 1999, p. 31). No norte da África e no Oriente Médio, a situação não foi diferente. O comércio de ouro controlado pelas dinastias muçulmanas (almôadas e almorávidas) através do Saara, que teve seu auge entre os séculos XI e XIV, começa a entrar em decadência durante o período da Reconquista com a chegada dos comerciantes italianos (NIANE, 2010, p. 698-705), os quais ganharam força nas décadas seguintes à passagem da peste pelo Magreb. Nesse momento, também cresce o poder de outro império muçulmano, o do Mali. De acordo com Niane (2011, p. 8),

Comerciantes e peregrinos negros encontram-se pelas encruzilhadas do Cairo; estabelecem-se embaixadas negras nas cidades do Magreb; intensificam-se as relações culturais e econômicas com o mundo muçulmano, sobretudo no século XIV, sob o reinado do faustuoso mansa Mūsā I e sob o do mansa Solimão; no Sudão central, Kanem e Bornu têm relações ainda mais frequentes com o Egito e a Líbia.

Além desse quadro de transformação geopolítica, durante o século XIV, período no qual Ibn Khaldun viveu 68 dos seus 73 anos, a África é palco de "grandes correntes de intercâmbios culturais" (NIANE, 2011, p. 697). O Magreb, que desde o século XI recebia influxos árabes, vê as populações berberes, povos nômades que habitam o norte da África (Argélia, Egito, Líbia, Marrocos, Tunísia) e o Saara, serem superadas em número pelos novos habitantes árabes (ALATAS, 2015, p. 15). Ao mesmo tempo, essa mesma região mantinha-se politicamente fragmentada, com graves problemas econômicos e sob constante ameaça de invasores (ALATAS, 2015, p. X). A história do Magreb do século XIV até o final do século XVI sob os herdeiros magrebinos dos almôadas, isto é, os Marínidas, os Zaiânidas ('Abd al-Wādid) e os Hafsidas "é de uma lenta paralisação", afirma Mohamed Talbi (2010, p. 74).

É nessa área anteriormente dominada pelos berberes e então nas mãos dos árabes que a maior parte da vida de Ibn Khaldun se dá. É lá, na metade do século XIV, que ele vê a instabilidade política se amplificar com a chegada da peste negra e a sociedade ser engolida por uma imensa crise econômica e social. Até então, a partir do surgimento do islã, o território dominado pelos muçulmanos vivia, desde o século XII, um ciclo de desenvolvimento e intenso crescimento das relações comerciais. Sob os aiúbidas (11711250), o porto de 'Aydhab, no Mar Vermelho, era um dos mais movimentados do planeta, com o total de negociações comerciais aumentando de forma contínua até antes da chegada da peste negra, no século XIV. O transporte e a venda de mercadorias como marfim, ferro e ouro se tornaram cada vez mais constantes e prósperos. Em razão desse 
superávit, a armada almôada era tão imponente que Saladino solicitaria seu apoio na luta contra os navios cristãos que atuavam na parte oriental do Mar Mediterrâneo (NIANE, 2011, p. 742-750).

Tamanha riqueza, no entanto, seria também grande geradora de conflitos. Nas décadas que precederam a chegada da peste negra, os Zaiânidas de Tlemcen e os "Marínidas de Fés aproveitaram-se da fraqueza dos Haféssidas durante a primeira metade do século XIV para alargar seus respectivos domínios” (HRBEK, 2010, p. 104). Depois, quando a dinastia Hafsida encontrava-se fragmentada por uma disputa interna de poder, o sultão Marínida "marchou sobre Túnis (1347) e anexou o Reino Haféssida" (HRBEK, 2010, p. 104). Tal vitória seria tão impactante para Ibn Khaldun que ele passaria seriamente a considerar a esperança de um dia os Marínidas se tornarem capazes de reunificar o Magreb.

Até mesmo Tlemcen, local que atualmente fica na Argélia e onde Ibn Khaldun teria escrito Os Prolegômenos, foi uma região que passou do crescimento econômico para a instabilidade política em poucas décadas. Segundo Hrbek (2010, p. 108),

Embora o Estado de Tlemcen conhecesse período de expansão e abundância
sob o reinado do competente soberano Abū Hammū Mūsã II (1359-1389), na
segunda metade do século XIV foi ocupado duas vezes pelos sultões
Miarínidas, sendo palco, ainda, de incursões e revoltas árabes. Foi por essa
época que o grande historiador Ibn Khaldūn viveu em Tlemcen e serviu como
intermediário de Abū Hammū junto aos chefes dos grupos nômades árabes, o
que lhe permitiu compreender bem os mecanismos da vida política e da troca
de alianças.

É em razão dessa proximidade com os eventos sociopolíticos que o texto de Ibn Khaldun permite acessar uma perspectiva histórica de viés mais objetivo do mundo nos séculos XIV e XV. Com seu texto, ele pretende analisar as mudanças geopolíticas e responder a uma demanda do poder no qual está inserido, isto é, oferecer não somente uma explicação, mas também solução para o declínio das dinastias muçulmanas. Desde 1229, quando os reinos ibéricos se apoderam das ilhas Baleares (Maiorca) até 1492, momento em que o pequeno emirado násrida de Granada dá seu último suspiro, ocorre uma modificação no equilíbrio das forças geopolíticas que, apesar de constante, não é algo abrupto (HRBEK, 2010, p. 110) e muito menos evolui sem que os muçulmanos tenham buscado formas de superá-lo. O mesmo Hrbek (2010, p. 110) afirma que:

(...) os Marínidas tentaram várias vezes mudar o rumo da situação - no seu entender, apenas provisória - na Espanha e assim reconstituir o Império Almóada nas suas antigas fronteiras. Foi somente em meados do século XIV 
que a vantagem dos cristãos tornou- ${ }^{-}$se evidente, estando o Magreb reduzido à defensiva.

Portanto, entre os fatores para o declínio político e militar dos Estados muçulmanos magrebinos está o enfraquecimento do poder central por diversas forças centrífugas, das quais fazem parte indivíduos dissidentes das famílias reinantes, chefes de tribos nômades, xeques sufi e xarifes (HRBEK,2010, p. 110). Esses agentes lutavam para tomar parte no "exercício do poder (...) sem nenhuma preocupação com o que fosse de interesse geral" (HRBEK, 2010, p. 110), o que, por sua vez, tornava inviável alcançar uma estabilidade política mais duradoura. Além disso, há também uma dicotomia, que em muitos casos evolui para o enfrentamento, entre cidades litorâneas e grupos do interior do Magreb, fator ao qual somam-se as incursões e campanhas militares organizadas por cristãos franceses (os franj), venezianos, genoveses, valencianos e aragoneses (HRBEK, 2010, p. 111).

Esse contexto de peste negra, invasão mongol, instabilidade interna e o avanço político, militar e econômico dos povos europeus levou Ibn Khaldun a produzir uma obra na qual o desenvolvimento econômico está vinculado a um quadro político estável, formado por estruturas administrativas simples e concentradas em funções essenciais como defesa, diplomacia, finanças públicas e projetos e inspeção da infraestrutura (WEISS, 1995, p. 32). A obra Os Prolegômenos é, portanto, não só resultado do contexto no qual foi produzida, mas também uma busca pelo receituário capaz de produzir uma sociedade estável que pudesse superar o cenário de crises constantes no qual o autor estava inserido.

Por último, é importante indicar que o ambiente intelectual de Ibn Khaldun é posterior ao embate entre Al-Gazali, duro e famoso crítico da falsafa; e Averróis, defensor da filosofia produzida no mundo árabe. Soma-se a isso o fato de de o texto de Os Prolegômenos estar profundamente vinculado à forte presença das ideias do reformador religioso Ibn $\operatorname{Tūmart~}^{19}$ (c. 1078-1130), na região do Magreb (HOURANI, 2001. p.169).

\footnotetext{
${ }^{19}$ Em seu texto A unificação do Magreb sob os Almoádas, O. Saidi aponta que Ibn Tūmart defendia a "afirmação de um Deus único e a negação de tudo que não é Ele: divindade, associado, santo, ídolo" (SAIDI, 2011, p. 24), as "ideias dos mutazilitas, que consideravam Alá como puro espírito" (SAIDI, 2011, p. 25), a responsabilização daqueles que detinham o poder pela "conduta de seus súditos" (SAIDI, 2011, p. 25) e a utilização para o estabelecimento das leis o "Corão e a suna e, em certas circunstâncias, o consenso e o raciocínio por analogia" (SAIDI, 2011, p. 27).
} 


\subsection{VIDA}

Inevitavelmente marcado pelo seu tempo, Ibn Khaldun foi, antes de tudo, um pessimista e um personagem profundamente trágico. Filho de uma família de árabes, Wal̄̄ al-Dī 'n 'Abd al-Raḥmān ibn Muhammad ibn Muhammad ibn Abī Bakr Muhammad ibn al-Ḥasan Ibn Khaldun al-Hadramî nasceu em Túnis, no Magreb, no norte da África, em 1332. Em seu nome a palavra al-Hadramî é uma referência à região de Hadramaut, no Iêmen, local de onde seus antepassados vieram. Porém, a Banu Khaldun (Casa Khaldun) só se tornou poderosa em al-Andaluz, local onde os ancestrais do autor de Os Prolegômenos eram conhecidos como homens do saber e da política sob os impérios omíadas, almorávidas e almôadas (ALATAS, 2015, p. 2).

Portanto, a história da família e do próprio Ibn Khaldun é transnacional, próxima do poder e cultivadora do conhecimento. Desde a vida de seus ancestrais em Sevilha, em al-Andaluz, no litoral sul da Península Arábica ${ }^{20}$, para onde eles migraram por volta da metade do século XI, vindos do Iêmen, onde faziam parte de uma tribo da região do Hadhramaut, até a morte de Ibn Khaldun, no Cairo, então uma das maiores cidades do mundo, o que vemos é um clã muito próximo dos círculos do poder, sempre rodeado pelas novidades intelectuais e pelo apreço e o cuidado com a educação.

Muitos membros da família de Ibn Khaldun foram influentes políticos e eruditos durante as dinastias omíada, almorávida, almôada e Hafsida, em al-Andaluz, na Península Ibérica, e, em Túnis, no norte da África. A importante presença política desse

\footnotetext{
${ }^{20}$ Todos esses locais são profundamente marcados por rotas comerciais. Por exemplo, o Hadhramaut, região do Iêmen onde surge a família do autor de Os Prolegômenos, fez parte de uma das rotas mais movimentadas de comércio do mundo em boa parte dos séculos X, XI, XII e XIII. Essa rota cruzava o oceano Índico, ligando, pela força dos ventos das monções, além do Hadhramaut (que fica na parte sul da península Arábica), a costa oriental da África, o subcontinente indiano (ou península do sul da Ásia) até a ilha de Java. Cidades como Zanzibar, Mogadishu e Hormuz e regiões como o Estreito de Malaca, que separa a parte continental da Malásia (e também Cingapura) da ilha indonésia de Sumatra e é até hoje uma das mais movimentadas rotas marítimas do mundo, eram portos importantes desse comércio feito entre povos da costa leste da África, sul da península Arábica, Índia e outros países do sudeste asiático. Esse percurso era rico também em diferentes culturas, pois reunia muçulmanos árabes e africanos, judeus, chineses, indianos e malaios. A parte ocidental desse comércio, apesar da faceta multicultural dos comerciantes, era amplamente dominada pelos muçulmanos, que na época eram aqueles com mais recursos para a construção de barcos. Não por acaso, a Indonésia, que era um importante centro de comércio desde o século XII, em razão do Estreito de Malaca, é atualmente o país com a maior população muçulmana do planeta. Essa rota comercial também é evidenciada pelo percurso do clássico da literatura árabe Kalila e Dimna. Tal obra possui inegável vinculação com a compilação indiana Pañcatantra, datada do século I d.C., e traduzida para o pahlevi pela Escola de Tradutores Yundai Sapur, na Pérsia. Posteriormente, chegou ao árabe através do trabalho de Ibn Almuqaffa. O percurso de Kalila e Dimna mostra o quanto circulavam as ideias pelas regiões acima citadas e pelo mundo muçulmano medieval, capaz, em razão disso, de produzir indivíduos como Ibn Khaldun.
} 
clã se dá em um período que vai desde o século XI até o momento em que a peste negra atinge essa parte do mundo, em meados do século XIV (ALATAS, 2015, p.2), ou seja, de certa forma, seu último grande ato é a produção de Os Prolegômenos.

As ideias presentes na obra de Ibn Khaldun seguem os mesmos passos de seu clã. O mesmo impulso que espalhou povos, conceitos e pessoas às mais remotas partes do mundo está em Os Prolegômenos.

Parte de sua infância, portanto, ocorreu nas terras que havia sido dominada pela antiga civilização púnica, a qual tinha Cartago como sua capital (também conhecida como civilização cartaginesa). Ibn Khaldun conheceu pessoalmente as impressionantes ruínas da cidade que acabou destruída pelo Império Romano 1.500 anos antes de sua época. Ali, ele presenciou in situ as marcas históricas de uma civilização que surgiu, atingiu seu apogeu, entrou em decadência e, finalmente, sucumbiu aos invasores. Destarte, desde cedo, ele teve contato com a imagem da ascensão e do declínio de impérios, conceito que acabaria permeando sua obra.

Durante o século XIII, Túnis passou a receber vários grupos de árabes e judeus que vivam na Península Ibérica. A família de Ibn Khaldun, que havia mudado para Sevilha, em al-Andaluz, havia se tornado eminente na região por volta do século XI. Depois, durante o começo da Reconquista, já no século XIII, os Banu Khaldun decidiram partir para onde atualmente é a Tunísia. É nesse momento de encerramento da presença do poder árabe em al-Andaluz que os bisavós de Ibn Khaldun mudam-se para Túnis (ALATAS, 2015, p. 2).

O avanço das forças cristãs gerou enorme instabilidade no mundo muçulmano na Europa e praticamente desintegrou o poder existente nas terras do islã na Península Ibérica. O resultado desse movimento é o surgimento de pequenos califados, muitos deles com as fronteiras indeterminadas. O cenário político desses postos avançados do islamismo no Velho Continente eram dominados pela intriga política, por revoltas armadas, por golpes e pelo perigo da reconquista (GIORDANI, 1997, p. 106). Foi esse ambiente que os bisavós de Ibn Khaldun deixaram para trás.

Ibn Khaldun nasceu em 1332, em uma Túnis (FROMHERZ, 2010, p. 40) dominada pelos Hafsidas ${ }^{21}$. Seus primeiros anos de vida transcorreram em uma cidade

\footnotetext{
${ }^{21}$ Segundo a obra a History of the Maghrib in the islamic period, do historiador Jamil M. Abun-Nasr, após passar a fazer parte do império muçulmano, Túnis foi controlada pelos omíadas (698-750) e
} 
controlada por árabes, mas marcada pelo multiculturalismo. Por ser um porto importante e muito próximo a locais como Malta, Sicília e Sardenha, a cidade de Túnis era palco de intensas trocas comerciais e forte presença de estrangeiros.

Os primeiros estudos de Ibn Khaldun foram feitos em casa com seu pai, o qual também era um estudioso. Inicialmente, ele aprendeu a língua árabe; depois, se aprofundou nos estudos do Alcorão, livro que Ibn Khaldun afirmava ter decorado. Boa parte do que se sabe atualmente sobre esse momento da vida desse pensador se deve à autobiografia, que na versão de Os Prolegômenos para o português encontra-se em um apêndice ao final do primeiro tomo, entre as páginas 479 e 553.

Durante sua adolescência, Ibn Khaldun continuou estudando língua árabe, mas também voltou suas atenções para temas como religião, filosofia e direito. Seu aprendizado ocorreu na mesquita de Al-Zitouna (ESPOSITO, 1999, p. 291) - atual Universidade Ez-Zitouna ${ }^{22}$-, um dos mais antigos locais de ensino do mundo muçulmano. Lá, estudou jurisprudência malikita, os hadịt e poesia com Abu 'Abdallah Muhammad bin Jabir bin Sultan al-Qaysi al-Wadiyash, então a maior autoridade em hadīt em Túnis (ALATAS, 2015, p. 3). Durante seus anos de estudo na adolescência, Ibn Khaldun teve contato com inúmeros e importantes intelectuais. Entre todos esses professores, aquele que causou a impressão mais profunda no jovem Ibn Khaldun foi Muhammad b. Ibrahim Al-Abili, um mestre das ciências racionais (NASSAR, 1964, p. 103-114).

A influência de Al-Abili foi tamanha que Abu Zakariya Yahya Ibn Khaldun, o irmão de Ibn Khaldun, que também era historiador e estudou com os mesmos mestres, escreveu sobre a reputação de Al-Abili e seu poder sobre os governantes da cidade de Tilimsan. Tanto Ibn Khaldun quanto seu irmão acreditavam que Al-Abili era um dos homens mais sábios de seu tempo. Esse racionalista, que tinha enorme interesse pelos

abássidas (750-800). Na sequência, presenciou a ascensão e queda dos aglábidas, dinastia árabe do norte da África, que dominou a cidade entre 894 e 905, período no qual ela foi a capital da Ifríquia. Depois, foi dominada pelos fatímidas (909-973) e, em seguida, pelos ziríadas (973-1148). Logo após essa longa sequência de governantes muçulmanos, a região foi, por um breve período, parte dos domínios dos normandos (1148-1160) comandados pelo rei Rogério II, da Sicília, o qual também se apossou de Trípoli, Jirba, Mahdiyya, Gabis e Sfax. Esse pequeno interregno foi encerrado pelos almôadas, que dominaram e governaram Túnis de 1160 a 1229. Posteriormente, a cidade passou para o controle dos Hafsidas, entre 1229 e 1574. Portanto, quando a família de Ibn Khaldun mudou-se para Túnis, ela estava sob domínio Hafsida. Nesse momento, a cidade era a capital dessa dinastia e vivia seu auge.

${ }^{22}$ Lá também estudaram figuras como o enciclopedista e poeta do século XII Ahmad al-Tifashi e o geógrafo AbdallahTijani (LULAT, 2005, p. 70). 
trabalhos do filósofo e matemático persa Nasir al-Din, foi responsável pela educação de toda uma geração de professores e teólogos (FROMHERZ, 2010, p. 45).

Entre outros professores que são citados por Ibn Khaldun em sua biografia estão o andaluz Abd Allah Muhammad Ibn Nazal Al-Ansari e os tunisianos Abu Abdallah Muhammad Ibn A-Arabi Al-Haçairi; Abu Abdallah Muhammad Ibn A-Chuach AzZarzali; Abu'l Abbas Ahmad Ibn Al-Cassar; Abu Abd Allah Muhammad Ibn Bahr; Abu Abd Allah Ibn Allah Al-Jaiani; Abu'l Cacim Muhammad Ibn Al-Cacir; Abu Abd Allah Muhammad Ibn Sulaiman As-Sitti; Al-Hadrami; Abu'l-Abbas Ahmad Az-Zuawi; o racionalista, lógico, teólogo e matemático Abu Abd Allah Muhammad Ibn Ibrahim AlAbelli; e o doutor em jurisprudência malikita Abu'l Cacim Abd Allah Ibn Yusuf Ibn Riduan. Muitos desses sábios faziam parte da corte de Abu'l-Hasan, então comandante do Marrocos e do reino da Ifríkya (KHALDUN, 1958, p. 491-499).

A rotina de jovem estudante corria tranquilamente quando, antes de completar 17 anos, a vida de Ibn Khaldun é tocada pela tragédia. Primeiro, os nômades árabes derrotam Abu'l Hasan em uma batalha em Kairuan, uma cidade muito estratégica por estar à mesma distância do mar e das montanhas - praticamente no centro do território onde atualmente fica a Tunísia. Depois, o povo de Túnis se rebelou contra Abu'l Hasan (KHALDUN, 1958, p. 499). É nesse momento, em abril de 1348, com a cidade enfrentando uma sublevação popular que a peste negra chega.

Poucas semanas após a epidemia atingir Túnis, o número de mortos já rondava os milhares. Esse terrível momento deixaria cicatrizes profundas no autor de $O s$ Prolegômenos. Ele perdeu o pai, a mãe, amigos e muitos de seus professores para a doença. Órfão, Ibn Khaldun viu a peste engolir dinastias, dizimar as autoridades então existentes, destruir cidades inteiras e obliterar estradas e rotas comerciais. A civilização na qual ele vivia se estreitou empurrada pela drástica redução populacional causada pela moléstia (ALATAS, 2015, p. 274).

O próprio Ibn Khaldun, em sua biografia, afirma que, após três anos estudando com Al-Abili, em Fez (BOUM; PARK, 2016, p. 244), cidade para qual ele foi após perder os pais, ele acabou convidado a trabalhar para o governo de Túnis principalmente em razão da peste. Segundo ele (KHALDUN, 1960, p. 503-504),

(...)após a grande epidemia que arrebatou nossos homens mais notáveis, nossos sábios, nossos professores e que me privou de meu pai e de minha mãe (...) Ibn Trafaguin, que então era todo poderoso em Túnis, mandou me 
convidar para desempenhar o papel de escrivão da alama junto de seu soberano Abu Ishac.

Portanto, Ibn Khaldun não viveu em uma "era de inquestionável supremacia da cultura medieval islâmica", como ocorreu com Avicena (GUTAS, 2003, p. 44). Ao contrário, sua vida adulta foi marcada por muita instabilidade e pouca certeza no futuro. Suas primeiras oportunidades no mundo da política e da jurisprudência surgiram muito em função da enorme falta de pessoal qualificado para exercer tais funções. Tanto é assim que Ibn Khaldun foi inúmeras vezes disputado por poderosos que o queriam em suas cortes. Porém, é possível afirmar que, apesar das circunstâncias produzidas pela peste, a formação e a carreira de Ibn Khaldun lembram muito as de Averróis (Ibn Rushd), principalmente em razão de seus amplos conhecimentos sobre a jurisprudência malikita - escola de jurisprudência caracterizada pela forte ênfase no hadi $\underline{t}^{23}$ e a sua participação ativa em questões de Estado.

Seu primeiro trabalho foi como mestre de assinatura (sahib al-'alama). Talentoso, Ibn Khaldun, no entanto, não gostava do que fazia ou do posto que ocupava (ALATAS, 2015, p. 4). Mesmo assim, o jovem burocrata passou a fazer parte dos círculos mais centrais do poder em Túnis.

Tempo depois, em 1354, ele seria enviado para fazer parte da corte e conselho científico do sultão em Fez, de quem também seria secretário. Apesar de aceitar com "repugnância" o trabalho, Ibn Khaldun aproveitou sua estadia naquela cidade para continuar seus estudos com o doutor na ciência das leituras corânicas Ibn As Saffar Abu Abd Allah Muhammad, com o jurisconsulto Al-Macarri Abu Abd Allah Muhammad, com o filósofo, teólogo e jurista Al-Haçani Abu Abd Allah Muhammad (Al-Alui), o diplomata e gramático andaluz Al-Burji e o xeique Ibn Abd Ar-Razzac Abu Abd Allah Muhammad (KHALDUN, 1958, p. 503-504).

Lá, ele seria totalmente envolvido por um ambiente de traições e tentativas de golpe que dominavam a corte de Abu Ishaq. Ibn Khaldun acabaria se tornando próximo de Muhammad (Maomé), o antigo líder almôada que estava preso em Fez. O autor de Os Prolegômenos acabaria sendo acusado de atuar ao lado de Muhammad para que esse escapasse e reconquistasse os territórios que antes dominara (ALATAS, 2015, p. 5). Em

\footnotetext{
${ }^{23}$ Os hadịts são textos que compilam citações e feitos atribuídos ao profeta Muhhammad e que fazem parte da sabedoria religiosa islâmica.
} 
razão disso, Ibn Khaldun foi incriminado por conspiração e acabou preso durante dois anos (1357-1358).

Abu Ishaq faleceu logo após Ibn Khaldun deixar a prisão. O governo de Túnis então passou para as mãos do filho do sultão, Abul-Baqa. Esse, no entanto, seria derrotado pelas forças comandadas pelo líder Hafsida e governante da cidade de Constantine, Abul-'Abbas (ABUN-NASR, 1993, p.129), o qual levou Ibn Khaldun para uma excursão militar fora de Túnis. O próprio Ibn Khaldun afirma em sua biografia que pretendia abandonar a tropa tão logo encontrasse uma possibilidade, tamanho era seu desgosto de estar naquela campanha militar ao invés de estudando com seus mestres (KHALDUN, 1958, p. 501).

Portanto, em um momento em quem o líder Mansur B. Hamza era o incontestável senhor do interior da região onde hoje fica a Tunísia (ABUN-NASR, 1993, p.129), Ibn Khaldun fazia parte de um excursão militar vinculada a um poder totalmente urbano que acabaria derrotado por esse chefe tribal. Após o fracasso, Ibn Khaldun passaria dias se escondendo em casas de conhecidos até conseguir escapar da região. Nas semanas seguintes, o autor de Os Prolegômenos atuou da maneira mais pragmática possível. Ao perceber a chance de Mansur se tornar o grande líder da região, Ibn Khaldun mudou de lado e aceitou ser seu secretário. Na sequência, após o sultão marinida Abu Salim se declarar rei da região, Ibn Khaldun trocou novamente de senhor e passou a ajudar Abu Salim a obter o apoio de líderes e xeiques menores daquela área. Assim, em 1359, quando Abu Salim assumiu o trono, Ibn Khaldun se tornou seu principal secretário (ALATAS, 2015, p. 6, tradução nossa).

Dois anos depois, Ibn Khaldun recebeu uma segundo e importante cargo, o de juiz na corte mazalim (ou corte administrativa), uma instituição distinta e constantemente em oposição à shari'ah ou ao sistema legal corânico. A corte mazalim era extremamente importante para os regimes dos sultanatos. Era uma espécie de departamento administrativo dos governos islâmicos que havia se tornado norma naquela parte do mundo muito antes do tempo de Ibn Khaldun. Esse sistema jurídico foi inicialmente importado do sassânidas pelos abássidas. Seu alcance administrativo sem obstáculos refletia a natureza imperial do califado, bem como o caráter autocrático/pragmático dos sultanatos regionais. ${ }^{24}$

A participação de Ibn Khaldun na corte mazalim não durou muito. Em 1362, o sultão Abu Salim morreu durante uma revolta. Temendo represálias, em razão de suas

\footnotetext{
${ }^{24}$ Tradução nossa do texto presente no capítulo três do e-book: DALE, Stephen Frederic. The orange trees of Marrakesh: Ibn Khaldun and the Science of Man. Harvard University Press: Harvard University Press, 2015. ISBN 978-0-674-96765-6.
} 
decisões na corte, o autor de Os Prolegômenos decidiu abandonar Fez e mudar-se para Granada, em al-Andaluz, onde ele chegou em dezembro do mesmo ano (FISCHEL, 1967, p. 16). Ibn Khaldun também decidiu mandar sua família para a cidade de Constantine (ALATAS, 2015, p. 6), região que atualmente fica na Argélia.

Em al-Andaluz, o poeta e escritor Ibn Al-Hatīb (ou Ibn al-Khatib), um grande amigo de Ibn Khaldun, atuava como vizir. Rapidamente, Al-Hatīb o indica para trabalhar na embaixada de Sevilha, no território controlado pelo rei Pedro I de Castela, o Cruel (1334-1369). Nesse momento, Ibn Khaldun participa da produção do tratado de paz entre cristãos e muçulmanos. Pedro, que sabia da história dos Banu Khaldun em Sevilha, ficou tão impressionado com o pensador árabe que o convidou para reassumir as propriedades de seus antepassados e permanecer em território cristão. Ibn Khaldun declinou o convite do líder cristão, mas conseguiu formalizar o acordo de paz (ALATAS, 2015, p. 6).

Essa experiência também seria muito importante na vida de Ibn Khaldun, então com pouco mais de 30 anos. Em Sevilha, ele observou em primeira mão uma das mais profundas mudanças geopolíticas de seu tempo com a ascensão dos reinos cristãos e a derrocada dos árabes na região ${ }^{25}$.

Pedro I de Castela, o Cruel não foi o único a ficar bem impressionado com Ibn Khaldun. Ibn Al-Ahmar, o sultão de Granada, ficou tão feliz com os resultados dos trabalhos do autor de Os Prolegômenos que decidiu lhe conceder a aldeia de Al-Bira ou Elvira (KHALDUN, 1958, p. 512). Porém, esse momento de bonança logo terminaria. Segundo o próprio Ibn Khaldun (1960, p. 512-513),

\section{Inimigos ocultos e caluniadores vis trabalharam, depois, com o fim de despertar as suspeitas do vizir, chamando sua atenção para a minha intimidade com o sultão, e para a extrema benevolência que o príncipe me testemunhava.}

Ibn Khaldun afirma também que essas intrigas acabaram minando a confiança que o vizir Ibn Al-Hatīb, seu velho amigo, tinha a respeito dele (KHALDUN, 1958, p. 513). Sentindo que sua vida em Granada estava se tornando perigosa e após receber a comunicação de que o sultão Abu 'Inan havia recapturado a cidade de Bougie -

\footnotetext{
${ }^{25}$ Ibn Khaldun foi um homem envolvido em política. Isso permitiu vivenciar o momento histórico no qual uma civilização, a árabe muçulmana, caminhava para a periferia mundial enquanto os cristãos europeus ganhavam espaço. Tal processo de decadência acabou sendo central em sua obra Os Prolegêmenos. É importante notar que esse mesmo período produziu as figuras do Trecento italiano, como Dante, Petrarca e Boccaccio, pensadores que viveram em uma sociedade que se desenvolvia e dava os primeiros passos em direção à Renascença.
} 
atualmente Béjaïa, na Argélia -, Ibn Khaldun decidiu retornar ao norte da África, onde se envolveu em disputas políticas entre líderes tribais ao ser enviado como chanceler em Biskra. Nesse mesmo momento, seu irmão Yahya é preso em Bona (ALATAS, 2015, p. 7) - atualmente Annaba, na Argélia. É possivelmente a partir desse trabalho com os líderes tribais e na luta para auxiliar o irmão preso que o autor de Os Prolegômenos começou a criar seu conceito de asabiyyah ${ }^{26}$, segundo o qual há um sentimento de grupo que fortalece algumas sociedades e atua como motor político capaz de levar um determinado grupo a tornar-se uma importante dinastia.

Depois dessa passagem, em 1364, entre os chefes tribais do Magreb, Ibn Khaldun conseguiu mudar-se para Tlemcen e posteriormente para Qal'at Ibn Salāma, perto de Tiaret - atualmente na Argélia -, onde dedicou-se aos estudos. Nesse momento, ele produziu sua obra mais importante: Os Prolegômenos. Inicialmente, Ibn Khaldun passou alguns anos praticamente isolado em Qal'at Ibn Salāma escrevendo a obra. Depois, em 1378, voltou para Túnis para consultar as livrarias e as fontes históricas da cidade (ALATAS, 2015, p. 9).

Apesar de já ser experiente, Ibn Khaldun continuou sofrendo ao se deixar envolver por intrigas entre os poderosos de Túnis. Em razão desses problemas políticos, ele, em 1382, anuncia que pretende fazer o Hajj (DALE, 2015, p. 2817). Ao conseguir a autorização dos governantes da cidade, embarca em direção ao Cairo, no Egito, deixando mulher e filhos em Túnis. Ibn Khaldun desembarcou em Alexandria. Dias depois, finalmente chegou à capital do sultanato mameluco. No dia 5 de fevereiro de 1383, ele descreveria sua chegada ao Cairo como uma (KHALDUN, 1958, p. 536)

\footnotetext{
${ }^{26}$ Algumas das ideias políticas presentes em Os Prolegômenos têm entre suas fontes a República de Platão. Foi dessa obra e das versões produzidas a partir dela, em árabe, que Ibn Khaldun retirou muitos dos conceitos que ajudariam a formar seu modelo político de califado islâmico de forte liderança. Apesar disso e de sabermos que, como afirmou Averróis, "o livro de Aristóteles sobre governança [i.e., Política] ainda não chegou às nossas mãos" (AVERROES, 1974, p. 4, tradução nossa), ou seja, que a obra aristotélica sobre política não teria alcançado o mundo árabe do século XIV, não podemos, no entanto, deixar de apontar que o conceito de asabyiia, em Ibn Khaldun, em muito se aproxima, por exemplo, da ideia de bem comum de Aristóteles presentes na obra Política. Segundo Shlomo Pines, trechos da Política de Aristóteles estariam presentes em trabalhos feitos em árabe no formato de "recensão da Política diferente do texto que nós conhecemos" (PINES, 1986, p. 149, tradução nossa). Para Pines, tais ideias teriam alcançado o mundo árabe e, consequentemente, Ibn Khaldun. Em seu texto "Aristotles' Politics in arabic philosophy", Pines afirma que é possível acreditar que algumas ideias presentes na obra Cidade virtuosa (Al-Madina al-fadila), de Al-Fārābī - que Ibn Khaldun conhecia -, "foram retiradas de alguma recensão, paráfrase ou sumário da Política de Aristóteles" (PINES, 1986, p. 153, tradução nossa). Isso poderia ser uma possível explicação para algumas semelhanças entre Os Prolegômenos e a Politica de Aristóteles. Contudo, mesmo que não exista qualquer ligação entre um texto e outro, é possível notar em ambos grande semelhança de conceitos, o que, por sua vez, mostra como a perspectiva de determinados pensamentos, nesse caso a lógica aristotélica e sua relação com a realidade social, é capaz de infiltrar suas bases nos mais diferentes textos e produzir resultados muito parecidos.
} 
(...) entrada na metrópole do universo, o jardim do mundo, o formigueiro da espécie humana, o pórtico do islamismo, o trono da realeza, cidade que regorgitava de magníficos palacetes e castelos, ornada de conventos de dervixes e de colégios, iluminada por luminares de saber e estrelas de erudição.

Quando Ibn Khaldun chegou ao Cairo, cidade que simplesmente o arrebatou, o sultão Barquq havia acabado de conquistar o poder - ele comandaria os mamelucos entre 1382 e 1399, ano de sua morte. O sultão acabaria convidando Ibn Khaldun a ocupar os cargos de professor e juiz (qadi), além de garantir-lhe um ótimo salário e lucrativos compromissos (ALATAS, 2015, p. 10).

Em razão dessa recepção financeiramente muito positiva, a vida de Ibn Khaldun no Cairo rapidamente se estabilizou e ele pospõe a ideia do Hajj para mais tarde - Ibn Khaldun só realizaria sua viagem a Meca entre os anos de 1387 e 1388 (DALE, 2015, p. 2260). Após dois anos na cidade do Cairo, ele decidiu pedir ao sultão a permissão para trazer sua família de Túnis. Com a concessão obtida, Ibn Khaldun tomou as providências necessárias para que sua esposa e filhos embarcassem o mais rápido possível. Nesse momento, Ibn Khaldun é vítima de uma nova e terrível tragédia. O navio que trazia seus familiares naufraga perto de Alexandria e todos seus entes queridos morrem. Ele narra essa fatalidade como uma espécie de destruição completa (KHALDUN, 1958, p. 544):

\begin{abstract}
Assim, num só golpe, perdi para sempre riqueza, felicidade e filhos. Prostrado pelo infortúnio e pela desgraça, procurei consolação na oração, e houve um momento em que pensei demitir-me de meu cargo; mas, receoso de descontentar o sultão, ouvi os conselhos da prudência, e continuei no posto. $\mathrm{O}$ favor divino não tardou em me socorrer nessa aflição.
\end{abstract}

O sultão cairota, que acabaria se apiedando de Ibn Khaldun, colocou-o sob sua proteção e o liberou de seus encargos na cidade. Ibn Khaldun passou três anos em luto. Depois, ainda remoendo a desgraça, decidiu fazer o Hajj, peregrinação à cidade de $\mathrm{Meca}^{27}$.

Ao retornar para o Cairo, ainda sob os efeitos da solidão produzida pela catástrofe familiar, Ibn Khaldun decidiu dedicar-se completamente aos estudos e ao ensino. Antes disso, no entanto, passou certo tempo em Jerusalém, onde fez inúmeras conferências.

\footnotetext{
${ }^{27}$ Os muçulmanos acreditam que realizar o Hajj possibilita ao crente se tornar tão puro quanto no dia em que nasceu. Em razão disso, a peregrinação a Meca tem, para os praticantes dessa religião, uma enorme força restauradora. O Hajj é um dos cinco pilares fundamentais do islamismo. Os outros são: afirma que "não há deus senão Deus, e Muhhammad é o mensageiro de Deus"; rezar cinco vezes ao dia em direção a Meca; doar para a caridade o corresponde a 2,5\% de sua renda anual; e jejuar no mês de Ramadã.
} 
Durante o tempo em que viveu no Cairo, Ibn Khaldun escreveu outras obras. Uma biografia, o resto da gigantesca obra História universal (Kitāb al- ibar), além de diversos trabalhos sobre gramática árabe. O pensador magrebino também permaneceu atento às disputas políticas ao seu redor. Em seus escritos ele revela quão complexa era a situação vivida pelo sultão em sua corte. Cercado por conspirações, insurreições, tentativas de golpes e constantes rebeliões Barquq (morto em 1399) chegou a ser deposto entre 1389 e 1390. Ao recuperar o poder, o sultão, grande vencedor da Batalha de Shaqhab, decidiu perdoar seus inimigos e retornou todos eles aos seus antigos postos. Ibn Khaldun elogiou tais decisões em seus escritos (KHALDUN, 1958, 545).

No final de sua vida, Ibn Khaldun assumiu o posto de professor de hadīt e lei corânica do centro mais importante de ensino do Cairo: a universidade de Al-Azhar. Lá, ele ministrou aulas sobre Os Prolegômenos, o que para muitos foi o primeiro curso de ciências sociais da história. É importante notar que Ibn Khaldun viveu no Egito em um período no qual as escolas daquela região "florescem e imprimem à civilização muçulmana um brilho especial" (KHALDUN, 1958, 545). Ibn Khaldun também entrou em contato com inúmeros pensadores, alguns dos quais foram inclusive mencionados em sua obra (KHALDUN, 1960, p. 130):

\begin{abstract}
Encontrei no Egito muitas obras sobre ciências intelectuais escritas por um personagem muito conhecido pelo nome de SAAD AD-DIN AT-TAFTAZANI, nativo de Herat, uma das cidades de Khoração. Seus tratados sobre Escolástica, sobre Fundamentos da Jurisprudência e Retórica evidenciam que possuía conhecimentos muito profundo nestes ramos de ciência e indicam, por muitos motivos, ser muito versado nas ciências filosóficas e intelectuais.
\end{abstract}

Ibn Khaldun, no ano de 1400, ainda voltaria a ocupar uma importante posição política. Isso ocorreu quando as forças comandadas por Tamerlão (1336-1405) chegaram aos portões de Damasco. O sultão mameluco daquela cidade, Malik Al-Nasir Faraj, pediu o auxílio de Ibn Khaldun nas negociações com o líder dos invasores (KHALDUN, 1958, p. 547).

Muito provavelmente Ibn Khaldun teria visto na liderança exercida por Tamerlão e em seus comandados o espírito da asabiyyah, ou seja, os requisitos necessários para colocar esse conceito em prática (BAALI, 1988, p. 48). Os dois teriam conversado sobre a história do norte da África e também dos mongóis e dos tártaros. Apesar da inegável boa impressão que Tamerlão causou em Ibn Khaldun e de o líder turco-mongol ter garantido a segurança de estudiosos e burocratas, incluindo o próprio 
Ibn Khaldun (ALATAS, 2015, p. 13), o pensador não conseguiu evitar o saque e a invasão da cidade de Damasco.

De volta ao Cairo, Ibn Khaldun retomou o trabalho. Revisou seus escritos e seguiu atuando como juiz e professor. O autor de Os Prolegômenos morreu em março de 1406. Ele foi enterrado no cemitério sufi do Cairo (BAALI, 1988, p. 3). 


\subsection{OS PROLEGÔMENOS}

Dividido em três tomos em sua versão para o português, a obra de Ibn Khaldun Os Prolegômenos ou Filosofia social (Al Muqaddimah) é a introdução e o Livro primeiro de outro trabalho maior do mesmo autor: os sete volumes que formam seu Kitab al-'ibar wa-diwan al-mubtada' wa-al-khabar fi ayyam al-arab wa-al-ajam wa-albarbar, título que pode ser traduzido por Livro de exemplos e coleções das origens da história dos árabes e dos berberes (ALATAS, 2015, p. 21, tradução nossa), mas que também é conhecido por História universal.

O texto de Os Prolegômenos é, portanto, um preambulo teórico e explicativo do conteúdo histórico de Kitāb al-ibar. Nele, Ibn Khaldun procura apresentar os mecanismos que fazem girar a máquina da história. A obra também é uma espécie de apresentação enciclopédica do conhecimento existente até então. Para muitos, o livro de Ibn Khaldun trata temas que já teriam sido debatidos nas obras de Al-Fārābī e nas epístolas da enciclopédia Ikhwân al-safâ' (ALATAS, 2015, p. 21). A diferença entre $O s$ Prolegômenos e as obras anteriores está na forma, apesar de alguns historiadores afirmarem que há muita semelhança entre o trabalho de Ibn Khaldun e Ikhwân alsafâ ${ }^{28}$.

Enquanto nos dois primeiros há um olhar mais filosófico, em Ibn Khaldun é possível ver, em inúmeras passagens, uma preocupação maior com a utilização dos fatos como fundamento de muitas teorias. Ele procura explicar como os seres humanos vivem. Como eles se reúnem, como se formam as cidades e como as sociedades progridem. Nesse sentido, ele, apesar de fazer inegavelmente parte de uma tradição dentro do pensamento árabe, busca uma nova leitura da realidade.

Na versão em português, o livro primeiramente apresenta uma introdução à obra, a qual não deve ser confundida com o texto geral. Nessa parte temos, portanto, os prolegômenos de Os Prolegômenos. É o trecho no qual o autor trata dos erros cometidos

\footnotetext{
${ }^{28}$ Ikhwân al-safâ' é eonsiderada uma das mais completas enciclopédias do período que vai do século IX ao XIII (BAFFIONI, 2016). Formada por um material extremamente heterogêneo, ela foi inclusive motivo de certa polêmica quando o historiador egípcio Mahmoud Ismail afirmou que Ibn Khaldun teria retirado parte de suas ideias da $I k h w a n$ al-safa'. Porém, essa polêmica não ganhou força. Segundo o intelectual marroquino Khalid Chaouch, os trabalhos de Ibn Khaldun são originais. O mesmo é dito pelo historiador Mohammad Abdullah Enan. Na verdade, essa polêmica não faz muito sentido principalmente em razão de a noção de autoria, à época de Ibn Khaldun, ser muito distinta da atual.
} 
pelos historiadores que o antecederam e onde ele diz que um dos objetivos de sua obra é corrigir tais equívocos (ALATAS, 2015, p. 23).

Em seguida vem o Livro primeiro (Kitab al-awwal), o qual está dividido em 6 partes espalhadas pelos três tomos da tradução feita por José Khoury. Assim, a Introdução mais o Livro primeiro formam a obra que conhecemos hoje por Os Prolegômenos.

No entanto, além desses três tomos, teríamos também o Livro segundo (Kitab althani), onde o autor narra a história das dinastias árabes desde a era pré-islâmica até a chegada do islamismo e trata ainda das dinastias persas, assírios babilônios, egípcios, israelitas, nabateanas, gregas, romanas e turcas. Depois, teríamos o Livro terceiro (Kitab al-thalith), que tem como foco as dinastias magrebinas e a questão da autoridade real. Portanto, Kitāb al- 'ibar era originalmente uma obra de sete volumes, do qual Os Prolegômenos representam apenas o primeiro volume. O Livro segundo vai do volume 2 aos 5 e o Livro terceiro do volume 6 ao 7 (ALATAS, 2015, p. 23).

Logo, tanto a tradução feita por José Khoury quanto a produzida por Franz Rosenthal trazem apenas a Introdução e o Livro primeiro divido em seis partes, ou seja, algo em torno de um sétimo do total da obra. De acordo com Alatas (2014, p. 157, tradução nossa),

\begin{abstract}
A primeira tradução de Muqaddimah em uma língua europeia foi feita por William MacGuckin de Slane entre os anos de 1862 e 1868. Depois, tivemos a tradução resumida de Charles Issawi, que recebeu o título de $A n$ arab philosophy of history (Uma filosofia árabe da história). Ela foi publicada em 1950. A edição feita por Issawi é uma útil introdução à obra de Ibn Khaldun em função de ter sido organizada por temas como método, geografia, economia, finanças públicas, religião e política. No entanto, a tradução considerada referência é a que foi feita por Franz Rosenthal (...) Publicada em 1958, ela inclui uma valiosa discussão, presente na introdução feita pelo tradutor, sobre a vida de Ibn Khaldun, sobre os vários aspectos do texto e sobre alguns detalhes da história do texto em si (...) uma excelente tradução para o francês foi feita por Vicent Monteil e publicada, entre 1967 e 1968, sob o título Discours sur l'historie universelle (...) não há, no entanto, uma tradução completa de Kitab al-'ibar.
\end{abstract}

Em razão do momento histórico no qual foi produzida a obra Os Prolegômenos, há nela um fator que hoje a distingue, qual seja: sua organização e a maneira como os temas foram tratados. Ibn Khaldun une geografia, história, sociologia, teologia, filosofia e economia em um mesmo espaço.

Na obra de Ibn Khaldun, o fracionamento do pensamento era diferente do atual, ao qual estamos tão acostumados. O texto corre em outra chave organizacional e os 
temas vão se apresentando conforme a ordem estabelecida e seguida pelo autor. Para Ibn Khaldun, a "ciência" era um

corpo autoconsistente de generalizações demonstráveis a respeito das mudanças históricas, generalizações que poderiam ser tomadas como base para premissas retiradas de resultados demonstrados a partir de conhecimentos 'superiores', i.e., ciências mais abstratas (HODGSON, p. 479480, tradução nossa).

Em razão disso, o conteúdo de Os Prolegômenos não se preocupa com muito com o que hoje podem ser consideras fronteiras entre os assuntos. Na obra, os limites atualmente considerados evidentes entre alguns temas acabam mais tênues e, em muitos casos, simplesmente não existem. Outro fator relevante de sua abordagem é ser "decididamente materialista" (ALATAS, 2015, p. 75). Por exemplo, Ibn Khladun “considera as diferenças entre as sociedades beduínas e sedentárias em termos de fatores econômicos e geográficos" (ALATAS, 2015, p. 75). Consequentemente, é comum entrar em um capítulo que se inicia abordando a questão dos preços dos produtos nas cidades (KHALDUN, 1959, p. 243), caminha para uma análise sobre as condições geográficas de determinadas regiões (KHALDUN, 1959, p. 245) e se encerra fundamentando uma ideia teológica ao concluir o texto com a seguinte frase: "Allah regula as vicissitudes das noites e dos dias" (KHALDUN, 1959, p. 246).

Essa peculiaridade, por conseguinte, permeará nossa análise, a qual pretende apresentar as ideias presentes no texto sem buscar enquadrá-las totalmente nas divisões atuais. Por exemplo, nas várias ocasiões em que ele faz referência à oferta e à demanda como mecanismos importantes para a determinação dos preços, suas ideias são profundamente diferentes das que lemos hoje em manuais de economia. Prova disso é que Ibn Khaldun acredita que bens de luxo (supérfluos) produzem inicialmente um impacto positivo na divisão do trabalho ${ }^{29}$, mas negativo a médio e longo prazo em função da frouxidão moral que inserem na sociedade. O pensador árabe chega inclusive a afirmar que, por essa exata razão, os salários dos trabalhadores com mão de obra qualificada são mais altos em cidades maiores porque tais locais possuem mercados consumidores também maiores (SUN, 2014, p. 28), nos quais cabe também o comércio de luxo.

\footnotetext{
${ }^{29}$ Para a economia atual, os bens de luxo são os bens que apresentam curva de demanda mais elástica, isto é, são aqueles produtos ou serviços não essenciais que apresentam maior demanda quando os salários ou a renda são altos. No entanto, a questão ética relacionada à aquisição de tais produtos praticamente não existe na discussão econômica atual, principalmente aquela com viés mais cientificista e matematizante.
} 
Tudo isso serve para evidenciar o quanto Ibn Khaldun é peculiar ao utilizar conceitos que séculos depois acabariam reduzidos a determinadas escolas do pensamento econômico. Portanto, nesse sentido, a construção de seu texto ocorre em uma chave diferente da dos modelos de pensamentos econômicos que surgiriam mais tarde na Europa.

Outro importante traço do texto de Os Prolegômenos é sempre partir daquilo que o autor considera mais geral para só então chegar aos temas mais específicos. O método que ele utiliza na confecção de sua obra e o tratamento que ele emprega aos fatos históricos baseia-se no método indutivo-dedutivo de Aristóteles desenvolvido nos Analíticos posteriores (ou Segundos analíticos).

Sua investigação da história dos povos é feita sobre as regras da lógica, a qual, segundo Ibn Khaldun (1960, p. 124),

(...) garante o espírito contra os falsos julgamentos e ensina como encontrar o termo desconhecido que se procura, por meio de princípios que se possuem e que se conhecem. Sua utilidade consiste em fazer distinguir o verdadeiro do falso nas questões que se prendem aos conceitos e às noções afirmadas, tanto essenciais como acidentais, para que o investigador chegue a constatar o verdadeiro em toda coisa pela força de sua faculdade refletiva.

No primeiro discurso preliminar da primeira parte do primeiro tomo, por exemplo, Ibn Khaldun utiliza esse método para explicar desde como se formam os primeiros tipos de organização social e quais são as opiniões dos filósofos a esse respeito. Ele também mostra como a lógica subjacente presente nas leis criadas pelos profetas são capazes de tornar as sociedades mais coesas (KHALDUN, 1959, p. 133). Nesse ponto, o objeto de Ibn Khaldun é a história humana e seu percurso desde a vida nômade à sedentária, tema que o autor destrincha. Ibn Khaldun procura dar conta do conhecimento a respeito da formação das civilizações. Para isso, analisa, entre outras coisas, o que se acreditava ser textos de Aristóteles sobre política (KHALDUN, 1958, p. 97) e os trabalhos de Galeno (KHALDUN, 1958, p. 107) a respeito da utilização da mãos para a subsistência, além da importância das profecias.

Há inclusive grandes semelhanças de organização de texto entre $O s$ Prolegômenos e A Política de Aristóteles. As duas obras partem da formação das cidades, ou seja, das origens do Estado. Em Aristóteles (2002, p. 1-6), esse ponto está na introdução de A Política; em Ibn Khaldun, no "primeiro discurso preliminar", o qual fala da reunião dos homens em sociedade (KHALDUN, 1958, p. 105). Essas 
semelhanças chegam ao ponto de Ibn Khaldun afirmar, nas primeiras páginas de seu $O s$ Prolegômenos, que os "filósofos expressaram pela máxima seguinte: 'o Homem é, por natureza, citadino"” (KHALDUN, 1958, p. 105), em uma clara referência ao "anthropos physei politikon zoon" presente também no início da obra aristotélica ${ }^{30}$.

Ao mesmo tempo, Ibn Khaldun segue a noção platônica, que aparecerá no mundo árabe nos textos de Al-Fārābī, para quem "a ideia de filósofo, rei supremo, príncipe, legislador e imam são a mesma coisa" (AL-FĀRĀBĪ, 1995. p. 43-4, tradução nossa). Portanto, Ibn Khaldun, ao defender que o bom líder é aquele que possui qualidades como "o saber, a probidade, a competência e o uso dos sentidos e dos membros que influem sobre a atividade do espírito e do corpo" (KHALDUN, 1958, p. 348), mescla, em suas ideias políticas, teses que remetem a Aristóteles e Platão. Porém, em razão de ser um pensador realista, Ibn Khaldun está mais próximo do "anthropos physei politikon zoon" que do idealismo político de Al-Fārābī e da "cidade perfeita que ocorre na República de Platão" (PINES, 1986, p. 157, tradução nossa). O objetivo, no entanto, é enquadrar a organização social em uma ideia ainda maior: a de que o islã é o grande princípio de organização política a ser seguido. É a religião, segundo ele, que produz o progresso:

\begin{abstract}
Para levar estes filhos do deserto a se compenetrarem do espírito administrativo e da arte de governar, é necessário que a influência da religião lhes modifique o caráter e extirpe a indolência. Tendo dentro de si um sentimento que os controla, trabalham para manter os súditos em ordem, contendo-os uns pelos outros. Vejamo-los na época em que fundaram um império sob a influência do Islamismo. Conformando-se com as prescrições da lei (divina), entregam-se aos cuidados do governo, empregando todos os meios físicos e morais capazes de fomentar os progressos da civilização (KHALDUN, 1958, p. 267).
\end{abstract}

No geral, no entanto, Ibn Khaldun obedece à mesma organização da obra aristotélica. A grande diferença reside na quantidade dos temas. Em Os Prolegômenos os assuntos são tratados em grande detalhe. Enquanto A Política de Aristóteles está dividida em quatro livros, dos quais o primeiro tem três capítulos; o segundo, cinco; o terceiro, seis; e o quarto, cinco. A obra de Ibn Khaldun é amplamente mais detalhada. Por exemplo, na obra de Aristóteles há algumas páginas sobre a localização da cidade e a importância de sua posição geográfica (ARISTÓTELES, 2002, p. 85-92); na de Ibn

\footnotetext{
${ }^{30}$ Tal conceito foi traduzido para o português por Roberto Leal Ferreira como "o homem é naturalmente feito para a sociedade política" (ARISTÓTELES, 2002, p. 4), versão que também apresenta a frase "o homem é um animal cívico" (ARISTÓTELES, 2002, p. 5), em inglês, essa frase foi majoritariamente traduzida com a seguinte construção: "man is by nature a political animal" (ARISTOTLE, 1952, p. 446).
} 
Khaldun, os temas geográficos vão desde "a parte habitada da Terra" (KHALDUN, 1958, p. 111), ou seja, a descrição das regiões até então conhecidas do mundo, no “Quinto Discurso Preliminar” (KHALDUN, 1958, p. 136), e passa por uma dissertação sobre os diferentes climas, onde é possível ler que a "alimentação influi na existência do corpo". Ibn Khaldun chega até mesmo a apresentar uma explicação a respeito da alimentação que cada região é capaz de produzir e como essas dietas podem alterar o comportamento humano (KHALDUN, 1958, p. 136-143). Ibn Khaldun utiliza a arquitetura aristotélica, porém a amplia incluindo temas que o filósofo grego ou tratou em outras obras ou simplesmente não tratou.

Ibn Khaldun também afirma que (1958, p. 97)

O "Tratado de Política", atribuído a Aristóteles e que se acha na mão do público, contêm muitas observações do mesmo gênero, mas que não são apresentadas sob a forma de um estudo completo, acompanhado de argumentos e provas, além de virem de permeio com outras matérias ${ }^{31}$.

Logo, há em Ibn Khaldun um método para a construção das ideias que é sempre o mesmo e em muito remete à mesma lógica presente em textos de Aristóteles, para o qual, "o intelecto humano sempre vai da potência ao ato, ou seja, ele primeiro possui o conhecimento geral para só depois chegar às aplicações específicas desse conhecimento" (SPANGLER, 1998, p. 123). Assim, Ibn Khaldun vai dos temas mais abrangentes para os mais específicos, porém, sempre apontando para uma espécie de entropia social. Para ele, quanto maior for o número de fatores (pessoas, trabalhos, impostos, disputas políticas, produtos etc.) mais essa civilização tenderá inevitavelmente à desordem e ao declínio, ou seja, maior será sua entropia.

\footnotetext{
${ }^{31}$ Aqui é importante apontar que o texto original dessa obra de Aristóteles não teria chegado às mãos de Ibn Khaldun. Segundo afirmou Averróis, "o livro de Aristóteles sobre governança [i.e., Política] ainda não chegou às nossas mãos" (AVERROES, 1974, p. 4, tradução nossa), ou seja, a obra aristotélica sobre política não teria alcançado o mundo árabe do século XIV. Apesar de Ibn Khaldun seguir a ideia aristotélica de que o ser humano é, por natureza, um ser político, o texto ao qual ele se refere não é de Aristóteles. A Política de Aristóteles possivelmente só chegou a Ibn Khaldun em segunda mão, isto é, inserida em textos de outros autores. O texto de Ibn Khaldun também segue Aristóteles ao começar falar das sociedades desde suas associações pré-políticas. Em Os Prolegômenos o que temos são noções de antropologia, sociologia histórica e economia que concordam fundamentalmente com princípios aristotélicos (LORD; O'CONNOR, 1991, p. 50). Portanto, apesar de vários conceitos presentes em Os Prolegômenos não estarem diretamente ligados aos textos originais de Aristóteles, é possível observar certa fidelidade à terminologia aristotélica, o que torna o texto de Ibn Khaldun notável em razão exatamente da inexistência da Política de Aristóteles no mundo muçulmano dos séculos XIV e XV. Aliás, segundo Muhsin Mahdi, o próprio Ibn Khaldun duvidada da autenticidade do texto aristotélico (2016, p. 286). Sabemos, no entanto, que para a obra Cidade virtuosa (Al-Madina al-fadila) de Al-Fārāāi - obra que Ibn Khaldun conhecia -, a Política de Aristotéles teve "grande importância arquitetônica" (PINES, 1986, p. 156).
} 
Em razão disso, são muitos os pontos nos quais a obra de Ibn Khaldun é recheada por um olhar pessimista da história das civilizações, "característica que ele compartilha com seu contemporâneo Ibn al-Khatib" (KNYSH, 1999, p. 185, tradução nossa), o que de certa forma corresponde à vida atribulada e às inseguranças enfrentadas pelo autor, mas também a essa lógica subterrânea à construção do texto. O livro busca ainda consolidar uma certa visão de como fazer "ciência da História" (KHALDUN, 1958 , p. 4) e como estudar as sociedades. No primeiro tomo, Ibn Khaldun explica porque essa área do conhecimento é importante e qual é a correta maneira de fazê-la (KHALDUN, 1958, p. 4-5).

Portanto, uma das principais marcas do texto é a importância da análise de viés silogístico de certos fatos sociais. Por esse motivo, alguns deles, como a teoria valortrabalho, foram escritos primeiro, apesar de aparecerem no meio do texto do segundo tomo nas edições que chegaram até os nossos dias. Esse detalhe é apontado em nota de rodapé na tradução feita por José Khoury (KHALDUN, 1959, p. 239) e também nas versões de outros tradutores.

Em razão desse apreço aos fatos e ao método, nas primeiras páginas da versão em português, Ibn Khaldun faz um apanhado dos problemas mais comuns encontrados em outras obras. Entre os exageros e erros de cálculo apontados por ele estão até os da tradição bíblica. Ibn Khaldun critica, por exemplo, Al-Mas 'ūdī quando este escreve que Moisés teria um exército de 600.000 soldados. Segundo Ibn Khaldun, por questões de logística, tamanha força jamais seria capaz de marchar ou lutar como uma unidade militar, pois não seria possível para um comandante visualizar e controlar tantos soldados de uma vez só (KHALDUN, 1958, p.19).

Dessa forma, as críticas que Ibn Khaldun faz aos historiadores e pensadores que o precederam vão desde as questões mais simplórias até aquelas de fundo filosófico. Seu texto, desde o início, procura refundar a maneira de tratar os assuntos aos quais se dedica utilizando continuamente a mesma estratégia: partir do comum para chegar ao singular e utilizar a lógica como "sistema de regras por intermédio das quais se distingue o que é bom do que é defeituoso" (KHALDUN, 1960, p. 156).

Quanto aos tomos, é possível dizer que, no primeiro, Ibn Khaldun faz um apanhado do conhecimento geográfico, sociológico e antropológico e científico produzidos até então. Ele também traça uma pequena história das civilizações árabes - 
para muitos, esse esforço já é suficiente para colocar Os Prolegômenos na raiz do desenvolvimento das ciências sociais.

No tomo segundo da versão em português - que será analisada com mais minúcia aqui -, Ibn Khaldun continua o trabalho sociológico e político do primeiro volume, o qual possui a primeira e a segunda parte completas e apenas um trecho da terceira parte. Em função disso, o tomo segundo começa no capítulo XXXII da terceira parte iniciada no tomo anterior. Apresenta textos sobre as diversas formas de governo que o autor conhecia. Entre elas estão as dinastias, a realeza, o império, o califado e o sultanato. Na quarta e na quinta parte, Ibn Khaldun trata da questão considerada central para esse estudo: a formação econômica dos povos. Primordialmente, o autor analisa a vida nas cidades. Explica os grandes centros urbanos desde sua fundação até as diversas formas de trabalho, comércio e conhecimentos que esses lugares abrigam.

Ainda no tomo segundo da versão em português temos o começo da $6^{\mathrm{a}}$ e última parte, a qual se dedica exclusivamente às ciências e ao conhecimento. Portanto, o tomo terceiro é uma continuação da $6^{\mathrm{a}}$ parte. Nela, o autor analisa a jurisprudência, a teologia, as artes (literatura, poesia, a arte de compor com elegância, entre outras), as ciências (interpretação dos sonhos, filosofia, aritmética, álgebra, óptica, astronomia, lógica, física, medicina, agricultura, metafísica, alquimia, gramática e lexicografia).

Paradoxalmente, Ibn Khaldun é um ferrenho crítico da filosofia que ele amplamente utiliza como método em sua obra. Intelectuais como Muhsin Mahdi, Ann K. S. Lambton e Ben Salem Himmich afirmam que Ibn Khaldun assumiu a posição de ardoroso crítico da presença da filosofia na política e na ética quando se tornou um homem maduro. Há ainda alguns intelectuais como Louis Baeck que defendem que no momento histórico no qual o autor de Os Prolegômenos viveu não somente a teoria do conhecimento de fundo platônico como o racionalismo de viés aristotélico de Averróis estavam sob ataque.

Baeck chega inclusive a afirmar em nota que (BAECK, 1996, p. 99, tradução nossa)

Quando um estudioso árabe como Ibn Khaldun declara que escreveu seu livro com a ajuda de Deus e sem a instrução de Aristóteles, ele está se protegendo da crítica do establishment ortodoxo, que pode achar sua análise muito distante do kalam. 
No entanto, acreditamos que Ibn Khaldun não entendia a disputa entre filosofia e religião como um paradoxo ou muito menos que ele se inclinava em direção à segunda por mera acomodação política. A nosso ver, ele entendia os impasses entre essas duas áreas do saber como algo a ser superado sob a prerrogativa de que, para o autor de $O s$ Prolegômenos, um discurso, o religioso, era superior ao outro, o filosófico.

Na sua concepção, a filosofia havia produzido ferramentas excelentes como a lógica, a ciência da natureza (a física), as matemáticas, a aritmética, a música, a ciência da forma do céu (astronomia), a medicina, a ciência do cálculo, a ciência da partilha, a geometria (KHALDUN, 1960, p. 124-125). O autor de Os Prolegômenos, no entanto, criticava a metafísica ou a "procura do conhecimento do ser tal como ele é" (KHALDUN, 1960, p. 173), que, segundo ele, os filósofos consideravam "a fonte da felicidade suprema" (KHALDUN, 1960, p. 173). Esse era um dos principais pontos da filosofia que Ibn Khaldun reprovava. Para ele, "o que existe (...) é vasto demais para ser compreendido" (KHALDUN, 1960, p. 234). Aqui reside um dos grandes pontos de atrito entre a filosofia e a cosmovisão religiosa de Ibn Khaldun. Enquanto a primeira buscava compreender o ser tal como ele é, o segundo defende que "o homem não poderia compreender, em sua totalidade, nem os seres espirituais, nem os seres corporais" (KHALDUN, 1960, p. 234).

Portanto, Ibn Khaldun defende a constante presença do mistério no trabalho intelectual. Chega até mesmo a utilizar um trecho do texto sagrado como prova de que sua tese é correta "e Deus criou o que vós não sabeis (Cor. XVI; 8)" (KHALDUN, 1960, p. 229). Para ele, a pretensão da filosofia de retirar o desconhecido do mundo era um problema. Ibn Khaldun acreditava que os seres espirituais, segundo ele, objeto de estudo da metafísica, possuem uma essência que "nos é absolutamente desconhecida, que a compreensão não poderia alcançá-la e que o raciocínio é incapaz de nos fazer conhecê-la" (KHALDUN, 1960, p. 231).

O autor de Os Prolegômenos acreditava que "a natureza da alma e seus atributos, constitui uma matéria tão profunda, que não há meio algum de tomar conhecimento disso" (KHALDUN, 1960, p. 231). Ibn Khaldun hierarquiza o conhecimento da mesma forma vê essa hierarquia presente na sociedade. Para ele, que se entendia como resultado de uma família tradicional e culta, há uma ordenação social estabelecida por uma ordem superior e à qual não temos acesso. Isso estaria, na visão de 
Ibn Khaldun, presente também na realidade. Há nela algo inexplicável, superior a tudo e a todos, o que remete, por sua vez, a uma noção hierarquizada e, em certo ponto, inacessível da realidade. Ibn Khaldun entende que podemos até admitir que os filósofos estudem coisas como os "primeiros inteligíveis", porém, ele é taxativo ao afirmar aos seus leitores que no caso da metafísica ou da ciência divina nós "não devemos nos ocupar desses temas" (KHALDUN, 1960, p. 231), pois, segundo ele, “o verdadeiro crente deve abster-se do que não lhe diz respeito" (KHALDUN, 1960, p. 231).

O motivo dessa posição resulta da noção de que, para Ibn Khaldun, a essência dos seres espirituais é coisa que nos é absolutamente desconhecida. Ele entende que a “compreensão não poderia alcançá-la e que o raciocínio é incapaz de nos fazer conhecela" (KHALDUN, 1960, p. 231). Ibn Khaldun defende que há um "véu que se interpõe entre nós e estas essências" (KHALDUN, 1960, p. 231). Portanto, percorre a obra Os Prolegômenos a seguinte posição frente à filosofia: Ibn Khaldun utiliza a lógica como ferramenta para analisar a realidade, mas impõe a ela e ao pensamento filosófico do qual ela surgiu a barreira inexpugnável do texto sagrado e a impossível compreensão total de uma realidade que, no seu entendimento, está recheada de mistérios indecifráveis. Segundo ele, a ciência divina ou a metafísica (KHALDUN, 1960, p. 236)

\begin{abstract}
não conduz à meta que os filósofos tiveram em vista e, em redor da qual, giraram sem alcançar. Acrescentamos que encerra princípios contrário à lei divina e em oposição com o sentido evidente dos textos sagrados. A única utilidade que pode ter, pelo que podemos julgar, é aguçar o espírito, tornando-o mais apto de obter, por meio de provas e de demonstrações, a faculdade de raciocinar com exatidão e justeza. Isso deve ocorrer, por que a arte da Lógica impõe a obrigação de observar, escrupulosamente, as leis que regulam a forma e a composição dos silogismos.
\end{abstract}

É por isso que ele, em sua análise, destaca as limitações do "pensamento metafísico e dualista” (RABI, 1967, p. 33, tradução nossa) e soma à essa constatação três outros pressupostos metodológicos: “interpretação materialista dos elementos culturais, análise socioeconômica e a substituição mútua e dinâmica das causas e efeitos" (RABI, 1967, p. 33, tradução nossa). 


\section{CAPÍTULO 2}

\subsection{O CARÁTER DA TEORIA ECONÔMICA DE IBN KHALDUN}

Descrever mecanismos econômicos como faz Ibn Khaldun é tarefa difícil. Quando bem feito, tal exercício é capaz de desvendar comportamentos sociais profundos. Em sua obra Os Prolegômenos, o autor empreende uma busca pelas "propriedades naturais da civilização" (AL-JABRI, 1997, p. 150) e acaba por revelar não só a complexa realidade econômica das sociedades muçulmanas no século XIV, mas também mecanismos e conceitos econômicos que, em razão de sua profundidade e correção, vão reaparecer, tendo ou não vinculação com o texto khalduniano, em civilizações e textos posteriores. Para ele, a economia era algo com vida própria e, portanto, passível de ser transformada em objeto de estudo e analisada empiricamente. Nesse sentido, Ibn Khaldun buscou investigar e descrever os atores e os mecanismos econômicos de sua época através de um método de viés aristotélico e silogístico. Em função desse olhar, muitas de suas teorias, não por acaso, se perpetuaram ${ }^{32}$ ou reapareceram em outras épocas quando foram objetos de uma análise com viés semelhante.

Dentro dessa perspectiva, a teoria sobre a valoração do trabalho presente em $O s$ Prolegômenos é profundamente importante porque serve de alicerce para a estrutura

\footnotetext{
${ }^{32}$ Hoje, algumas das teorias presentes na obra de Ibn Khaldun são utilizadas por acadêmicos como o famoso professor de economia norte-americano Arthur Laffer, segundo o qual, o conceito "Curva de Laffer" seria, na verdade, baseado em uma criação do autor de Os Prolegômenos, que buscou, à sua época, explicar como políticas tributárias que incentivam produtividade e investimento são capazes de gerar crescimento não inflacionário. Esse mesmo conceito proposto em Os Prolegômenos também se tornaria, séculos mais tarde, a base da "teoria econômica do lado da oferta" (supply-side economics). Laffer participou do governo Reagan (1981-1989), nos Estados Unidos. A "Curva de Laffer" foi parte fundamental da política econômica dessa administração, a qual, seguindo os preceitos do economista, adotou drásticas medidas de redução dos impostos. Segundo a "Curva de Laffer", diminuir os impostos resulta em um aumento da receita tributária. O que impressiona nesse caso é um pensador do século XIV (Ibn Khaldun) defender a mesma política que um economista norte-americano da atualidade (Arthur Laffer). Ambos acreditam que quanto menor for a taxação, mais os atores econômicos se tornam dispostos a investir na produção, o que, por sua vez, ajuda a aumentar a arrecadação. De certa forma, o que está por trás da semelhança entre os escritos de Ibn Khaldun e de outros pensadores que o sucederam, como Hobbes, Adam Smith, Ricardo e até mesmo Karl Marx, é a fonte. Todos eles utilizaram, cada um com sua peculiaridade, o racionalismo e o método indutivo-dedutivo de Aristóteles ao analisar a realidade. A obra de Ibn Khaldun é portanto repleta de ideias econômicas ainda presentes no mundo atual. Entre as mais relevantes estão conceitos como a teoria de valoração do trabalho, o direito à propriedade, a flutuação de preços, a acumulação de capital e o comércio internacional.
} 
lógica da obra. Atua como se fosse a primeira premissa, já que parte do geral - qualquer relação entre trabalho e o valor dado ao bem por ele produzido - para chegar ao particular: a relação entre os trabalhadores do Magreb e a formação dos valores dados aos bens que eles produzem. Ibn Khaldun percebe que o valor das mercadorias é resultado direto da função do tempo de trabalho necessário para produzi-las (KHALDUN, 1959, p. 277). Uma sociedade capaz de atribuir valor corretamente ao que nela é produzido será necessariamente formada por uma teia de relações sociais mais complexa. Destarte, a obra Ibn Khaldun aponta que, nas sociedades muçulmanas, que entre os séculos IX e XIV eram majoritariamente formadas por pequenos empreendedores, a correção na atribuição de valor viabiliza não só um mercado produtivo e eficiente, mas uma sociedade mais justa e coesa.

Novamente, a importância da teoria de valoração do trabalho resulta da organização lógica que permeia Os Prolegômenos. Ibn Khaldun defende a tese de que “a forma é anterior à matéria" (KHALDUN, 1959, p.274), isto é, ele segue o argumento de Aristóteles (1029 a 5-6), para o qual "a forma é anterior e mais ser do que a matéria, pela mesma razão que ela será anterior ao composto" (ARISTÓTELES, 2002, V. II, p. 293). O autor de Os Prolegômenos transpõe esse conceito aristotélico para a economia e a sociedade. Para ele, $U m r \bar{a} n^{33}$ é a forma anterior à matéria, que nesse caso pode ser entendida como a economia real de uma sociedade ou dinastia. Tal forma carrega em si as atribuições corretas de como deve ser valorada a produção. Logo, toda organização

\footnotetext{
${ }^{33}$ Esse termo na língua árabe, segundo Stephen Frederic Dale, deriva de uma raiz verbal que possui inúmeros significados. Entre eles estão: construir, viver, prosperar, popular, reconstruir, preservar e, em alguns casos, civilizar. Acreditamos que Ibn Khaldun usa o termo para se referir às noções de cultura e sociedade. Em Os Prolegômenos, o autor constantemente rivaliza os termos Umrān badawi e Umrān hadari quando se refere às sociedades ou culturas nômade, beduína ou tribal (badawi) e às sociedades $\mathrm{e}$ às culturas urbanizadas (hadari). Na introdução do e-book The orange trees of Marrakesh: Ibn Khaldun and the science of man, Stephen Frederic Dale aponta que sempre que esse termo aparece ele está se referindo ao modo de vida dos hadari ou dos badawi. O principal sentido de badawa é "primitivo", porém, para Ibn Khaldun, os povos badawa (beduínos, nômades ou sociedades vinculadas à agricultura $\mathrm{e}$ à agropecuária nas regiões dos oásis) são dotados de certas qualidades físicas e morais que estariam ausentes nos povos hadara, ou seja, nas populações civilizadas que habitam grandes centros urbanos. Essa é a tese de muitos autores, entre eles Louis Baeck, autor de Ibn Khaldun's political and economic realism e Stephen Frederic Dale. Portanto, Umrān, ou seja, a noção de civilização ou cultura em Ibn Khaldun, não é aquela "antissepticamente isolada de suas filiações mundanas" e sim "um campo de realização extraordinariamente diversificado" (SAID, 2005, p. 14). Nessa cultura ou civilização, seja ela hadari ou badawi, um dos principais fatores é a maneira como elas atribuem valor ao trabalho. Portanto, corcondamos com Murilo Sebe Bom Meihy quando o mesmo afirma que o termo Umrān, em Ibn Khaldun, "ao contrário da concepção recorrente de 'civilização' como contraposição à 'barbárie' (...) refere-se à existência mesma do ser humano no mundo, ressaltando a ordem instituída por Deus para a sua sobrevivência" (MEIHY, 2017, p. 71-72).
} 
social $^{34}$ acabará desembocando em algumas estruturas que, segundo o autor de $O s$ Prolegômenos, lhe são anteriores.

Ibn Khaldun indica a existência de uma teoria valor-trabalho que antecede o trabalho que ocorre na vida real e pode ser compreendida, estudada e utilizada como ferramenta teórica para explicar como a mão de obra se organiza dentro das sociedades ${ }^{35}$.

O texto de Os Prolegômenos reforça a importância do trabalho na manutenção da coesão social. É a partir desse ponto que ele desenvolve uma teoria que vai desde a valoração dos produtos à especialização da mão de obra e à divisão do trabalho. Para Ibn Khaldun, há uma relação entre a demanda por trabalho e o processo de urbanização

\footnotetext{
${ }^{34}$ A noção de "organização social" utilizada por Ibn Khadun remete à ideia greco-islâmica al-ijtima 'alinsani, que muitos autores traduzem por "associação humana" - "human association" - (BLACK, 2001, p. 127). Esse conceito, em Os Prolegômenos, soma-se à noção de al-mujtama "al-madani, a qual, por sua vez, muitos autores traduzem por "sociedade civil" ou "sociedade civilizada" - "civil society" (KAWTHARANI, 1992, p. 120) ou "civilized society" (BROWERS, 2006, p. 106). Obviamente, além da da noção de civilização ou sociedade que Ibn Khaldun separa nas categorias hadari e badawi, é preciso entender que tanto nas traduções quanto no texto de Os Prolegômenos esses conceitos se misturam à ideia de vida nas cidades e vida no campo ou no deserto. Logo, quando Ibn Khaldun fala em "urbanização" ele se refere à mecânica que, segundo ele, leva um grupo dotado de mais asabiyyah da vida nômade para a vida urbana. Foi essa tese que levou o tradutor José Khoury a verter, para o português, a frase "o fascínio da civilização constitui a suprema aspiração do beduíno" (KHALDUN, 1958, p. 208) enquanto na versão para o inglês, Franz Rosenthal, verteu a mesma passagem da seguinte maneira: "therefore, urbanization is found to be the goal of the Bedouin" (KHALDUN, 1967, p. 217). A diferenças das escolhas indica o quanto as ideias de sociedade, civilização e urbanização são semelhantes na obra. Porém, antes do estabelecimento de um vocabulário mínimo da obra khalduniana, é importante atentar para o movimento que ambas versões indicam, qual seja, o de que sociedades badawi dotadas de asabiyyah carregam em si a possibilidade de um movimento que as levara à urbanização, isto é, da mesma forma que uma semente é uma árvore em potência, uma sociedade ou civilização badawi é uma sociedade ou civilização hadari em potência. Segundo Ibn Khaldun, a primeira carrega em si o germe da segunda. É isso que vemos no XII capítulo do tomo primeiro da edição em português "Como os impérios passam da vida nômade para a civilização" (KHALDUN, 1958, p. 307), que na versão em inglês recebe o título: "The transition of dynasties from desert life to sedentary culture" (KHALDUN, 1967, p. 313).

${ }^{35} \mathrm{Hoje}$, em qualquer bom manual de economia, é possível encontrar um conceito semelhante que trata das tendências do mercado de trabalho. No entanto, apesar de tal teoria estar presente no texto de $\mathrm{Ibn}$ Khaldun, em nenhum momento, o autor se refere a essa ideia pelo termo ou conceito "teoria valortrabalho" pelo qual ela é hoje conhecida. Decidimos adotar esse tratamento por entender que ele facilita a compreensão da relação descrita por Ibn Khaldun. Portanto, sempre que ela aparecer no texto significará a relação entre a produção de algo e como esse algo recebe valor, ou seja, como se atribui valor ao trabalho nas sociedades retratadas em Os Prolegômenos. Mesmo sendo muito parecida com a noção atual, em razão de suas peculiaridades e de seu contexto histórico, o conceito valor-trabalho presente no texto de Ibn Khaldun apresenta certas particularidades que serão debatidas no texto. No entanto, é importante ressaltar que a maneira como Os Prolegômenos apresenta a valoração do trabalho se encaixa perfeitamente à teoria valor-trabalho presente na maioria dos manuais de economia. Essa foi a razão que nos levou a adotar tal termo. Mesmo assim, também é importante deixar claro que para a maioria dos economistas, a teoria valor-trabalho teria surgido nos escritos de Adam Smith (1723-1790) e recebido tal denominação somente na obra $O$ Capital, de Karl Marx, publicada em 1867. Portanto, quando usamos a teoria valor-trabalho para nos referirmos ao texto de Ibn Khaldun estamos, de certa forma, enquadrando o texto de Os Prolegômenos em uma história do pensamento econômico mais ampla do que a usual e fazendo uso de um conceito que se enquadra e facilita a compreensão daquilo que Ibn Khaldun, na tradução em português, trata como "preço do trabalho do homem" (KHALDUN, 1959, p. 277).
} 
que resulta do processo de distanciamento de determinado grupo da vida nômade para a vida nas cidades. Logo, quanto mais urbanizada se torna uma sociedade, maior será seu mercado de trabalho e sua capacidade produtiva (KHALDUN, 1959, p. 314). Em razão dessa estrutura, o autor de Os Prolegômenos acredita que qualquer administrador de uma cidade deve sempre visar a criação de uma economia vibrante e capaz de atrair empreendedores. Quando isso não ocorre, por exemplo, quando há intervenção do poder estabelecido (cobrança exacerbada de impostos ou interferência do poder governamental na produção com a intenção de reduzir ou controlar os preços), os trabalhadores e empreendedores acabam perdendo a motivação e a cidade sua produtividade. Segundo ele, “o preço vil de uma mercadoria é lesivo aos interesses dos que, por ofício, se ocupam desta espécie de mercadoria depreciada" (KHALDUN, 1959, p. 311). Portanto, Ibn Khaldun entende a esfera econômica, fundamentada a partir da correta valoração do trabalho, como o principal mecanismo de sustentação social e política desde que ela funcione longe das intervenções do Estado. Ele, de certa forma, repete aqui a mesma lógica presente na Musnad, coleção de tradições de Ahmad Ibn Hanbal, onde se lê que o Profeta, quando lhe solicitaram o controle dos preços dos "mantimentos em Medina, num período de escassez, ele respondeu que apenas Deus poderia fixar os preços" (MARGOLIOUTH, 2012, p. 400).

Já outros assuntos como comércio e lucro presentes na obra de Ibn Khaldun indicam o quanto o mundo islâmico diferenciava-se de outras regiões nesse período. Como vimos, na segunda metade do século XIV e começo do XV, quando Ibn Khaldun escreveu sua obra Os Prolegômenos, ocorria uma enorme transformação geopolítica. Boa parte do continente europeu entrava no que ficou conhecido como Revolução Comercial, iniciada no século XII, e que ganharia ainda mais força nos séculos seguintes. Em razão disso, Ibn Khaldun viveu em um momento no qual o poder árabe dava seus primeiros passos em direção à periferia do poder e da vida econômica mais internacionalizada. Tentando captar o espírito e a crise de sua civilização, o autor de $O S$ Prolegômenos se mostra um personagem amargamente inserido em seu tempo. Nesse sentido, Ibn Khaldun aponta tanto o que é disfuncional quanto o que dá certo nas economias desse período. Foi assim que ele tratou da valoração do trabalho, da expansão da riqueza e da produção vinculadas ao aumento populacional, do comércio e da obtenção de lucros e dos "ciclos sociais". 
O realismo socioeconômico presente nas análises sociopolíticas na obra de Ibn Khaldun andam lado a lado com a mentalidade de um tempo no qual a política, as leis, o poder e a religião eram uma coisa só. Economicamente falando, a história cíclica defendida por Ibn Khaldun resulta de uma tese presente no texto e já apontada por Louis Baeck. Em Os Prolegômenos teríamos pela primeira vez a indicação da não durabilidade do desenvolvimento (BAECK, 1996, p. 91). Para Ibn Khaldun, as sociedades não seriam capazes de manter o crescimento econômico infinitamente já que seu progresso carrega dentro de si o embrião da derrocada, o qual ganha força com o surgimento do comércio de luxo, da vida sedentária dos centros urbanos e da política fiscal restritiva que o dia a dia cada vez mais suntuoso dos governantes inexoravelmente produz. Para ele, a "Civilização da vida sedentária: é o termo além do que não há progresso (KHALDUN, 1959, p. 260). 


\subsection{VALORAÇÃO DO TRABALHO}

A maneira como as sociedades atribuem valor ao que é produzido dentro delas, ou seja, a "teoria valor-trabalho" presente no texto de Os Prolegômenos, é pedra de toque para inúmeras teses de Ibn Khaldun. Ela é, para o autor, o alicerce sobre o qual se organizam as sociedades e quaisquer relações comerciais ${ }^{36}$ que dentro delas existam.

Apesar de permear toda a obra, a atribuição de valor ao trabalho surge com mais força na quinta parte de Os Prolegômenos, a qual, em português, recebe o seguinte título: "Dos meios que se empregam para procurar a subsistência - Da aquisição - Das artes e tudo que se relaciona com elas" (KHALDUN, 1959, p. 277).

Depois, a linha fina que inicia o primeiro capítulo da quinta parte da versão em português na qual se encontra essa teoria diz: "Prova de que a aquisição é o preço do trabalho do homem" (KHALDUN, 1959, p. 277). Aqui encontramos o primeiro ponto a ser mais cuidadosamente analisado, principalmente no que diz respeito às diferenças entre as traduções. Na versão francesa, por exemplo, é possível ler algo bastante similar ao texto em português: "On prouve que celle-ci est le prix du travail de l'homme" (KHALDUN, 1936, p. 244). Porém, na versão em inglês está escrito: "Profit is the value realized from human labor" (KHALDUN, 1967, p. 689). A mesma diferença ocorre no título: as versões em português e francês utilizam, respectivamente, "aquisição" e "acquisition" enquanto a versão em inglês utiliza "profit".

Destarte, as versões em francês e português colocam o trabalho como um fator formador de preço e capaz de permitir que os indivíduos tenham acesso à aquisição de outros produtos. Ele seria, portanto, o mecanismo que dá valor às coisas produzidas e que possibilita trocas. Já a tradução para o inglês troca o "preço do trabalho" pelo conceito de lucro (profit) ${ }^{37}$, o que em si carrega uma enorme diferença. Nesse caso,

\footnotetext{
${ }^{36}$ Surge aqui o primeiro ponto que Alain de Libera chama de "herança esquecida" (LIBERA, 1999, p. 102). É muito comum encontrar hoje em manuais de economia um verbete sobre a teoria valor-trabalho. Invariavelmente, o que se lê é que esse conceito teria sido criado por Adam Smith e David Ricardo e posteriormente aprimorado por Karl Marx. Realmente, os três trabalharam e analisaram essa ideia. Porém, ao estudarmos Os Prolegômenos, percebemos a existência de conceitos muito similares presentes no texto de Ibn Khaldun, principalmente quando o mesmo trata temas como as relações econômicas em sociedades mais urbanizadas e as conclusões que ele atinge a partir da análise dessas relações.

37 Muitas leituras da teoria valor-trabalho feitas a partir da obra de Ibn Khaldun consideram principalmente (ou exclusivamente) a tradução feita em inglês e tratam da questão do lucro e não do trabalho como ferramenta para das valor às coisas.
} 
podemos entender que a versão inglesa estaria mais próxima de uma compreensão atual da teoria valor-trabalho.

Talvez aqui seja possível afirmar que a excelente tradução de Franz Rosenthal que foi aluno de Werner Jaeger e Richard Walzer na Universidade de Berlim, na Alemanha da década de 1930 - tenha sido contaminada por ideias que o tradutor tinha sobre a teoria valor-trabalho mas que não exatamente estão presentes no texto de Ibn Khaldun. É importante ressaltar isso porque o autor árabe obviamente não estava preso a nenhuma concepção clássica da teoria valor-trabalho posto que ele escreveu seu livro séculos antes das obras de Ricardo, Smith e do próprio Karl Marx. Em Os Prolegômenos, o termo árabe usado é "rizc" (KHALDUN, 1959, p. 278), palavra que se aproxima mais de "benefício" do que de "profit" - a utilização do termo "lucro" feita por Rosenthal também não acompanha o texto em árabe, que utiliza a palavra $k u$ 'nia (KHALDUN, 1959, p. 280) quando fala de lucro.

O lucro, para o autor, é certamente fruto do trabalho, porém, a palavra por ele utilizada na linha fina é "rizc" "38, a qual pode ser traduzida por benefício - termo utilizado na versão em português. É possível afirmar que no termo "rizc" (benefício) está presente a ideia de troca de mercadorias, isto é, para Ibn Khaldun, um carpinteiro

\footnotetext{
${ }^{38}$ A etimologia do termo árabe "rizc" ou "rizq" é muito interessante e pode ajudar a entender melhor esse ponto do texto de Ibn Khaldun. Geralmente, seu primeiro sentido em árabe é "provisão", isto é, tudo aquilo que uma pessoa pode fazer uso, desde a roupa que está vestindo até o dinheiro que possui. Rizc também pode ser traduzida como "subsistência" e "benefício", entre outros termos. Aqui, no texto traduzido por José Khoury, optou-se pela utilização da palavra "benefício" quando o texto em árabe traz "rizc". Apesar de não ser o primeiro sentido da palavra na maioria dos dicionários árabes por nós consultados, ela soluciona razoavelmente bem a questão, pois atende de forma mais completa à ideia que o texto de Ibn Khaldun propõe, que é a de que o trabalho gera vantagens para o trabalhador, as quais, por sua vez, podem incorporar em si as noções de subsistência, provisão e acúmulo de capital, todas elas representando algum tipo de benefício ao trabalhador além de ter uma ligação histórica com o termo rẽzq, do árabe magrebino. Para explicar essa ligação, devemos notar que os dicionários etimológicos que consultamos indicam que a palavra "risco", em português, estaria vinculada à história da palavra árabe "rizq". O termo "risco" em português, surgiu do francês "risque", que data aproximadamente de 1660. Tal termo também chegaria depois ao inglês, onde se tornaria "risk", vocábulo que data de 1700 . Em seguida, passaria ao italiano moderno "rischio", que significa "perigo ligado a uma atividade". Estas palavras, por seu turno, estariam vinculadas aos termos do latim pós-clássico "resicum" e "risikum", que, segundo o Oxford English Dictionary (2014), correspondem às ideias de "perigo", de "arriscar" e de "fortuna" ou "sorte". Todo essa história dos termos latinos estaria vinculada, por sua vez, às palavras "rhizikon", em grego, e "rizc" (provisão, subsistência, benefício), em árabe. No entanto, quando chegamos mais especificamente ao termo em árabe, notamos que ele se relaciona com o vocábulo rẽzq do árabe magrebino, no qual possui os seguintes sentidos: compensação, ganho, aquisição, alcançar, lucrar, valer, merecer, compensação, fortuna e possessão (HARRELL, 2006, p. 130). Portanto, apesar de a palavra do árabe magrebino rẽzq não apresentar entre seus sentidos o termo "benefício", seus três principais significados (compensação, ganho e aquisição) não estão em discordância de sentido com o termo escolhido por José Khoury, ao contrário, todos carregam em si a noção de receber ou conquistar algum "benefício". Já o termo "lucro" (profit) está hoje muito carregado da ideia de trabalhar para receber um salário, isto é, ser pago em moeda e, assim, acumular capital.
} 
pode trocar algo que produziu com um ferreiro sem que nenhum dos dois tenha lucro (profit) na negociação, mas ambos tenham sido beneficiados por ela.

$\mathrm{Na}$ sociedade muçulmana do século XIV, majoritariamente formada por microempreendedores, esse tipo de benefício não lucrativo - a troca - ocorria em grande número. Logo, o trabalho não deve apenas buscar o dinheiro e o lucro (profit), mas também ser capaz de dotar o trabalhador do poder de se beneficiar $(\text { rizc })^{39}$. Tal benefício pode ser através do dinheiro produzido pelo lucro ou pela simples troca de um produto por outro (KHALDUN, 1959, p. 279). Para Ibn Khaldun, uma sociedade desenvolvida será capaz de permitir intensas e extensas compras e trocas de mercadorias. Segundo ele (KHALDUN, 1959, p. 238-239),

quando os habitantes [das grandes cidades] repartem entre si o trabalho com
o fim de conseguirem as coisas que lhes são indispensáveis, o que se obtém é
uma quantidade suficiente para um número muito maior de indivíduos. A
produção, devido à cooperação, ultrapassa muito as necessidades dos
operários. O excedente é supérfluo e se emprega para satisfazer os hábitos de
luxo que esses trabalhadores teriam contraído, ou para servir ao
aprovisionamento de outras cidades cujos habitantes fazem a aquisição por
via de troca ou por compra. Desta maneira alcançam os trabalhadores certa
parcela de riqueza.

Portanto, apesar da divergência entre as traduções, já nesse ponto torna-se possível compreender que a obra de Ibn Khaldun confere um valor mais amplo ao trabalho e ao que dele resulta, superando dessa forma os textos escritos sobre esse assunto até então. Em uma sociedade economicamente vibrante, o surgimento do supérfluo, isto é, do excedente econômico, produz, segundo Ibn Khaldun, entre outras coisas, a possibilidade do comércio de luxo. Para ele, quando uma sociedade supera suas necessidades "indispensáveis", ela abre passagem para o acúmulo de capital através das negociações comerciais. Isso permite a popularização de comportamentos voltados para a ostentação. Logo, a riqueza que vem do comércio e se materializa em produtos de luxo, os quais são resultado direto da qualificação da mão de obra, da divisão do trabalho, do surgimento e crescimento das negociações comerciais e do sucesso econômico de uma sociedade ou região. O trabalho, para Ibn Khaldun, em razão de sua capacidade de beneficiar os indivíduos, os obriga também a formar amplos leques de relações sociais, sem os quais é impossível o "benefício" das trocas e o

\footnotetext{
${ }^{39}$ Nesse sentido, a concepção de trabalho de Ibn Khaldun se diferencia dos economistas clássicos e de outros pensadores como Marx, que viriam depois de Os Prolegômenos. Para ele, a valoração do trabalho passa pela capacidade do mesmo em beneficiar o trabalhador, permitindo-o fazer trocas envolvendo os bens que produz ou receber dinheiro por eles.
} 
processo de qualificação da mão de obra. Logo, o trabalho e sua correta valoração é a base para o funcionamento de uma sociedade, pois atua como mecanismo de manutenção da coesão social das grandes cidades, já nas "cidades onde há pouca população; benefícios e proveitos são parcos" (KHALDUN, 1959, p. 281). Assim, Ibn Khaldun encontra no trabalho seu ponto de partida para formalizar uma análise mais ampla do funcionamento das sociedades, pois é "necessário o trabalho do homem para tudo que é aquisição e tudo que é fundo de riqueza” (KHALDUN, 1959, p. 279).

Outro elemento para o que entendemos ser uma concepção mais abrangente do trabalho no século XIV surge no texto imediatamente após à linha fina da quinta parte. Lá é possível ler a seguinte afirmação (KHALDUN, 1959, p. 277):

O homem, em todos seus estados e em todos os períodos de sua vida, desde o nascer até à época em que atinge a força da idade, e desde então até alcançar a velhice, é por natureza obrigado a se alimentar e a procurar sua subsistência.

Há nesse parágrafo a evidência da compreensão do trabalho como algo intrínseco à natureza humana. Segundo Ibn Khaldun, somos obrigados a fazê-lo, pois sem ele nossa existência, ou melhor, nossa subsistência - conjunto dos recursos necessários para a manutenção da vida - se tornaria inviável. Assim, Ibn Khaldun acredita que todos os seres humanos são, em potência, trabalhadores citadinos.

Atualmente, em economia, o trabalho é o conjunto das atividades humanas empregado na produção de bens. Seu intuito principal é obter lucro. Na obra de Ibn Khaldun, há uma profunda e crucial diferença. Para o autor, a forma mais natural de buscar o lucro é o comércio, "arte de fazer crescer seu capital comprando mercadorias e procurando vende-las mais caro do que custaram" (KHALDUN, 1959, p. 305). Novamente, aqui fica evidente que o texto de Os Prolegômenos entende o trabalho dentro de uma função socialmente mais ampla. Nesse sentido, é possível constatar uma compreensão que tipifica não só a importância do trabalho para a manutenção da vida, mas também indica um traço da civilização muçulmana, a qual carrega em si uma espécie de "nova moral"

\footnotetext{
${ }^{40}$ A civilização islâmica trouxe para o mundo dos séculos VII e XV, "uma nova sociedade bem como um novo tipo de indivíduo. Os atos essenciais da devoção islâmica tinham cada um o seu aspecto social. Os muçulmanos rezavam juntos na mesquita às sextas-feiras; o seu jejum anual no mês do ramadã tinha não só o aspecto de um ato de disciplina, mas de uma grande cerimônia da corporação; vestidos com o branco da consagração, eles partiam juntos em peregrinação a Meca na estação apropriada; pagavam esmolas estipuladas na tesouraria central. A sharia abrangia as relações dos homens com Deus, e assim esses eram também atos de significado religioso, ordenados ou proibidos. Recusar o pagamento das taxas estipuladas
} 
período, se tornando peculiares ao islã nos séculos IX e XIV. Aqui é importante ressaltar que desde seu início o islã concatenou religião, trabalho e comércio. Meca, a cidade na qual Muhammad nasceu, era, de acordo com Margoliouth (2012, p. 21), "uma sociedade de negociantes (...) situada a curta distância de muitas feiras”. Com o passar do tempo, a Caaba se estabeleceu como o santuário mais importante para os muçulmanos e a cidade assim "assegurava certa renda proveniente dos estrangeiros, parcialmente constituída do imposto cobrado aos visitantes" (MARGOLIOUTH, 2012, p. 26). A Caaba fez de Meca um vibrante centro de comércio e um ponto de encontro de inúmeras tribos. É sob esse signo que surge essa nova moral.

Essa peculiaridade islâmica está presente no texto de Ibn Khaldun, o qual incorpora esse traço em sua análise das sociedades muçulmanas e na compreensão do trabalho e do comércio. Ambos, para ele, eram imprescindíveis para a acumulação de capital, mas funcionavam principalmente como fatores voltados para o desenvolvimento das cidades através da urbanização. Nesse sentido, os trabalhadores são importantes. Prova disso é que autor de Os Prolegômenos (KHALDUN, 1959, p. 208), ao falar de grandes monumentos e edifícios, credita aos trabalhadores, à coesão social e ao conhecimento (e não apenas a um determinado soberano) a capacidade de construí-los:

Para construir é preciso que os homens se prestem uma ajuda mútua e
empreguem meios para dobrarem suas forças naturais (...) às vezes, os
edifícios cuja construção foi projetada são tão grandes que sua execução fica
acima das forças humanas empregadas quer simplesmente, quer aumentadas
pelo emprego da mecânica. É necessário que forças semelhantes às primeiras
se sucedam durante uma sequência de tempo bastante longo para que a
construção destas obras seja levada a termo.

Portanto, Ibn Khaldun acredita que construções colossais só são viáveis quando uma série de fatores se combinam. Entre esses fatores, a figura do soberano é importante, porém, posterior ao surgimento da "ajuda mútua". É ela que deve incorporar e fazer ser respeita a profunda valorização do trabalho necessária para o progresso. $\mathrm{O}$ autor de Os Prolegômenos indica que somente uma cidade dotada de força de trabalho capaz, dona de conhecimentos em diversas áreas - como a da construção civil -, com um governo estável e socialmente coesa pode levar a cabo obras colossais, pois somente esse ambiente é capaz de produzir essa “ajuda mútua” (KHALDUN, 1959, p. 208).

na sharia e negar a obrigação de pagá-las era uma apostasia igual a negar a existência de Deus ou a validade da mensagem profética. A religião do islã criou não só uma estrutura de direitos e deveres, mas também uma solidariedade moral para sustentá-la" (HOURANI, 2005, p 22-23). 
Para Ibn Khaldun, o trabalho é intrínseco à vida e ganha novos aspectos e capacidade de execução em função do tamanho da civilização na qual está inserido e da qual é um dos alicerces. Nesse sentido, o surgimento das artes e da mão de obra mais qualificada são elementos comuns e constituidores de uma sociedade que ganhou complexidade. Para Ibn Khaldun, é totalmente natural que conforme uma cidade aumente em tamanho e se torne mais urbanizada dentro dela surjam novas profissões e novas formas de valorar o trabalho. Para ele (KHALDUN, 1959, p. 254),

A civilização da vida sedentária se compõe de hábitos de um gênero mais distinto daqueles cuja necessidade é absoluta e da qual nenhum povo pode prescindir. Esta superioridade se regula de conformidade com o número e a comodidade da população. Existem em tão grande número (esses hábitos) que não se pode assinar nenhum limite à sua diversidade, aparecendo entre todos os povos quando os efeitos da civilização se multiplicam, formando uma variedade de gêneros e diversas classes. Estas classes representam as artes necessitando de homens hábeis e treinados no ofício que lhes serve de subsistência. A medida que as artes adquirem seus caracteres distintivos, aumenta o número de artífices que formam cada classe, e a geração dessa época toma uma forte tintura de (conhecimentos práticos). Esta tintura se renova muitas vezes no decorrer do tempo, de tal sorte que os operários adquirem muita habilidade e grande conhecimento nos seus ofícios.

Nesse ponto, acreditamos que se faz necessário indicar a diferença dos estágios nos quais se encontravam a civilização muçulmana e o Ocidente cristão durante a segunda metade do século XIV e começo do XV, época na qual viveu o autor do texto que ora analisamos. No mundo cristão europeu, no mesmo período em que Ibn Khaldun escreveu sua obra, o trabalho ainda era visto de maneira dúbia, muita vez entendido como algo pouco digno e associado à punição e ao sofrimento ${ }^{41}$. O mesmo ocorria com o dinheiro e o lucro. Uma prova disso era a difícil situação dos banqueiros medievais na Europa. Segundo Jacques Le Goff (2014, p. 145),

Giovanni de Mirabello, piemontês estabelecido em Brabant, tornado grande banqueiro sob o nome de Van Haelen (cerca de 1280-1333), promovido a nobre e conselheiro do duque de Brabant (...) por denúncia particular, ficou preso em 1318-1319 pela municipalidade de Malines, o que mostra o caráter ainda ambíguo do dinheiro no início do século XIV.

\footnotetext{
${ }^{41} \mathrm{O}$ termo "trabalho" vem do latim tripalium, o qual, por sua vez, designava um instrumento de tortura. Já o verbo "trabalhar", em sua etimologia latina, vem de tripaliare, termo que significa utilizar o tripalium para produzir martírio físico em um determinado indivíduo. Segundo o Dicionário Houaiss, tripalium aparece na maior parte das línguas românicas (espanhol, francês e italiano) e deriva do verbo tripaliare (forma não atestada), do latim tripalium, por sua vez formado a partir do adjectivo tripális,e, que significa "sustentado por três estacas ou mourões".
} 
A palavra "trabalho", em seu sentido mais moderno só vai começar a dar seus primeiros passos no mundo ocidental cristão no final do século XV e vai obter "seu teor atual somente no século XIX” (LE GOFF; SCHMITT, 2002. v. 2. p. 559).

Há, portanto, algo fundamentalmente distinto sobre a ideia de trabalho e comércio nessas duas culturas e Ibn Khaldun, em seu texto, apresenta com exatidão e de forma detalhada como era essa noção nas sociedades muçulmanas. Para ele, as civilizações só se tornam poderosas quando corretamente atribuem valor ao trabalho e quando incentivam o lucro, pois é somente "por meio de seu próprio trabalho e tendo em vista o lucro" (KHALDUN, 1959, p. 277) que determinados indivíduos conseguem dominar determinadas artes, acumular riquezas e ajudar uma sociedade prosperar.

Ao contrário de como era visto o trabalho no mundo medieval europeu, Ibn Khaldun o entende como um mecanismo que funciona para racionalizar a realidade, pois ele é capaz de manter, organizar e tornar mais complexas e eficientes as sociedades. Só o trabalho torna os indivíduos e governos mais ricos e poderosos ${ }^{42}$.

Nesse ponto, Ibn Khaldun afirma que "o lucro que resulta da criação de gado, do cultivo das plantas e da exploração das minas não pode também se obter, senão mediante o trabalho do homem" (KHALDUN, 1959, p. 277). Portanto, enquanto no Ocidente o trabalho é compreendido de duas maneiras antagônicas: uma ignóbil; outra honrosa (LE GOFF; SCHMITT, 2002. v. 2. p. 559), ou seja, enquanto há no mundo cristão um claro enfrentamento entre o ideário franciscano, que buscava sua afirmação na recusa ao dinheiro (LE GOFF, 2014, p. 131), e aqueles que pretendiam incorporar os valores do comércio aos grandes centros urbanos ${ }^{43}$, no islã, segundo podemos ver no texto de Ibn Khaldun, essa luta simplesmente não ocorre ${ }^{44}$. Ibn Khaldun apresenta o

\footnotetext{
${ }^{42}$ Curiosamente, há aqui há uma semelhança muito forte entre as ideias de Ibn Khadun e o "racionalismo da dominação do mundo" de Max Weber. Ambos sustentam suas ideias a partir de um alicerce religioso: Weber utiliza para isso o protestantismo; Ibn Khaldun, por sua vez, o islamismo. Obviamente, não queremos com isso afirmar que uma obra está vinculada à outra. $\mathrm{O}$ que pretendemos apontar é a semelhança entre essas duas maneiras de compreender a realidade, as quais baseiam-se ambas na racionalização do real através da valoração do trabalho e têm como pano de fundo um pensamento religioso.

43 "O conflito entre o tempo da Igreja e o tempo dos mercadores afirma-se em plena Idade Média, como um dos acontecimentos maiores da história mental destes séculos, durante os quais se elabora a ideologia do mundo moderno, sob a pressão da alteração das estruturas e das práticas econômicas" (Le Goff, 1980, p.45).

${ }^{44} \mathrm{O}$ mundo islâmico, que produziu o apogeu da civilização árabe e intelectuais como Ibn Khaldun, misturou poder econômico e multiculturalismo. Desde seus primeiros passos, na era pré-islâmica, essa civilização já estava profundamente marcada por essas duas forças, sempre presentes em seus centros comerciais e religiosos. Meca é o símbolo maior desse contexto. Antes da criação do Islã, a cidade, chamada de Macoraba pelo geógrafo, matemático e astrônomo alexandrino Claudius Ptolemaeus
} 
trabalho dentro de uma perspectiva pragmática e racionalista ${ }^{45}$. Sem ele o que temos são "as forças de um indivíduo isolado" (KHALDUN, 1958, p. 106), as quais são “insuficientes para a obtenção da quantidade de que necessita" (KHALDUN, 1958, p. 106).

É em razão de possuir um papel crucial que o trabalho assume o posto de alicerce da teoria presente em Os Prolegômenos. Por ser um dos principais fundamentos para uma sociedade se manter viva, o trabalho é primordial em sua capacidade de dotar valor às coisas, de ajudar os seres humanos a dominarem a natureza, dar mais racionalidade à organização das grandes cidades e a gerar riqueza ${ }^{46}$.

Ao analisar a importância do trabalho nas sociedades, o autor de $O s$ Prolegômenos separa seus fundamentos. Ele diferencia subsistência ( $m a$ 'ach), riquezas (riach) e (mutawwal), benefícios (rizc), aquisição (kisb) e lucro (ku’nia) (KHALDUN, 1959, p. 278-280). Dessa forma, Ibn Khaldun separa a relação valor-trabalho por seus resultados.

(Ptolomeu), era uma espécie de entreposto de caravanas, ponto por onde passavam negociantes da região do Mediterrâneo, da África Oriental e do Sul da Ásia. Nesse incessante mundo de chegadas e partidas, pessoas e ideias deixavam inevitavelmente sua marca nas tradições locais. Em dias de comemorações, feiras ou festas religiosas, milhares de árabes se dirigiram para Meca. O trabalho e o comércio para essas populações jamais foram vistos como algum indigno. Segundo D. S. Margoliouth, em seu livro, Maomé e a ascensão do islã, de certa forma, religião e comércio concatenavam profundamente a cidade na qual Muhhammad surgiu. Em razão disso, nas ideias de Ibn Khaldun estão presentes conceitos como os benefícios do livre mercado, a sofisticação da produção em centros urbanos, a especialização da mão de obra, o comércio internacional, a cobrança de impostos, o papel do Estado na economia, os ciclos populacionais, a questão da oferta e da demanda, a política monetária, a precificação, o direito à propriedade e o trabalho como fonte de lucro. Portanto, a maneira paradoxal que o mundo ocidental e cristão da Idade Média tinha em relação ao trabalho e à riqueza não está presente nas sociedades muçulmanas analisadas por Ibn Khaldun, o qual descreve uma civilização na qual o trabalho, o comércio e o lucro são partes intrínsecas, formadoras e mantenedoras da coesão social.

${ }^{45}$ Esse mesmo racionalismo está presente nos trabalhos de outros pensadores de língua árabe como Avicena e Averróis. De certa forma, Ibn Khaldun bebeu da mesma fonte que posteriormente influenciaria o Ocidente, levando-o para a Renascença e o racionalismo. Ibn Khaldun era profundo conhecedor de Avicena e, de certa forma, seu texto é uma antecipação do que ocorreria na Europa cristã. Em seu livro Pensar na Idade Média, Alan de Libera afirma que é "com Avicena que a influência do pensamento muçulmano sobre a Idade Média latina adquire seu primeiro e verdadeiro contorno: este autor não apenas inicia o Ocidente na razão, no seu uso profano, em uma palavra, na ciência; ele o introduz também na racionalidade religiosa, uma racionalidade muito estrita posta a serviço pela primeira vez e rigorosamente, de uma religião monoteísta" (págs. 108 e 109).

${ }^{46}$ Aqui é importante frisar que a riqueza em si não é um problema para Ibn Khaldun. Ele a entende como resultado lógico de uma sociedade que está perto de seu auge econômico. O problema, para ele, são os comportamentos que a riqueza é capaz de produzir nos indivíduos, principalmente nos governantes, os quais passam a consumir bens de luxo apenas por ganância e não por necessidade. A riqueza não é vista como algo desprezível em si, o que em muito se difere da visão cristã medieval, a qual, entendia e retratava a riqueza como "criminosa mesmo. Nos retratos do inferno feitos à época, a bolsa em volta do pescoço aparece como um dos principais sinais de condenação" (RUSKIN, 2004, p. 24-25). 
Após afirmar que "é necessário o trabalho do homem para tudo que é aquisição e tudo que é fundo de riqueza" (KHALDUN, 1959, p. 280), seu passo seguinte é colocar a noção de trabalho no centro de sua teoria de valor (1959, p. 280):

(...) na maioria dos casos, é fácil reconhecer que se teve em conta o valor do trabalho e que se marcou um preço maior ou menor; mas em certos casos, não se percebe esta avaliação. É o que acontece, para a generalidade do mundo, no que se refere ao preço dos comestíveis. Quando se fixa o preço dos cereais, tem-se em conta certamente o trabalho e os gastos exigidos pela produção.

Ao assumir que qualquer mercadoria carrega em si "o trabalho e os gastos exigidos pela produção" "47 Ibn Khaldun torna os trabalhadores os grandes responsáveis pela capacidade produtiva e organizacional de uma sociedade ${ }^{48}$. Porém, aliada a essa capacidade surge um problema que também possui um viés estrutural, qual seja, grandes cidades tornam os indivíduos intrinsecamente dependentes uns dos outros, o que, no longo prazo, acaba afastando essa sociedade do sentimento de asabiyya. Nesse momento, a decadência da "cidade produz a decadência das artes que nela se cultivam" (KHALDUN, 1959, p. 320).

Para Ibn Khaldun, um dos principais fatores para manter um Estado socialmente coeso reside na sua capacidade de valorar o resultado do trabalho e obter lucro com o mesmo, isso porque "a diminuição das remunerações traz a diminuição dos rendimentos do Estado" (KHALDUN, 1959, p. 100). Essa mútua necessidade é a responsável por criar e remunerar corretamente as profissões. Porém, quando um povo sai da condição de nômade para a de sociedade urbana surgem novas carências e o trabalho automaticamente ganha complexidade. O autor de Os Prolegômenos entende que o

\footnotetext{
${ }^{47}$ Nesse ponto, é possível apontar certa semelhança com conceitos presentes em escritos posteriores como os David Hume, David Ricardo e Adam Smith, para os quais valor também é algo criado a partir de esforço físico, isto é, do tempo de trabalho gasto para produzir tal coisa. Segundo Adam Smith (1979, p. 11), "o trabalho anual de cada nação constitui o fundo que originalmente lhe fornece todos os bens necessários e os confortos materiais que consome anualmente. O mencionado fundo consiste sempre na produção imediata do referido trabalho ou naquilo que com essa produção é comprado de outras nações. Conforme, portanto, essa produção, ou o que com ela se compra, estiver numa proporção maior ou menor em relação ao número dos que a consumirão, a nação será mais ou menos bem suprida de todos os bens necessários e os confortos de que tem necessidade. Essa proporção deve em cada nação ser regulada ou determinada por duas circunstâncias diferentes; primeiro, pela habilidade, destreza e bom senso com os quais seu trabalho for geralmente executado; em segundo lugar, pela proporção entre o número dos que executam trabalho útil e o dos que não executam tal trabalho". Já David Hume (Essays, 261) afirma que "every thing in the world is purchased by labour; and our passions are the only causes of labour". Hume, que cita Averróis em sua obra History of Religion, conhecia os textos dos pensadores árabes.

${ }^{48}$ Portanto, é possível dizer que Ibn Khaldun está em consonância com autores que o sucederam, porque ele também entendia que a "economia, seja ela a de um estado, de um lar ou de um indivíduo, pode ser definida como a arte de gerenciar o trabalho" (RUSKIN, 2004, p. 26). Para Ibn Khaldun, quando os poderosos fazem esse gerenciamento corretamente, o resultado é a construção de grandes obras e o progresso econômico.
} 
crescimento de uma determinada cidade produz uma vida urbana onde é praticamente impossível atingir a autossuficiência, o que, por sua vez, obriga os moradores a diluírem as obrigações e os trabalhos entre si e os leva necessariamente a uma configuração social cada vez mais complexa, interdependente e formada por "escravos de seus hábitos de luxo" (KHALDUN, 1959, p. 261), os quais os levam a gastar "tudo o que ganham e se deixar cair, uns após os outros, na pobreza e na miséria" (KHALDUN, 1959, p. 261). Isso os distância do espírito mais sóbrio e independente presente na vida mais autossuficiente dos grupos sociais marcados pela asabiyya. Para ele (KHALDUN, 1959, p. 95),

\begin{abstract}
O soberano, recebendo todo o rendimento, ou pelo menos a maior parte, acumula dinheiro para poder prover à administração pública e às suas necessidades. Suas riquezas crescem, as arcas se lhe enchem de dinheiro, a carreira do fausto se abre na sua frente, e o poderio real sobrepuja então o de todo povo reunido. As pessoas ligadas a seu serviço, vizires, empregados civis, camareiros, libertos, até os soldados de sua guarda, tornam-se personagens importantes; desfraldando grande luxo, ganham e acumulam rios de dinheiro.
\end{abstract}

Esse enriquecimento, por sua vez, produz a derrocada dessa sociedade, que para manter todo esse fausto aumenta os impostos até um ponto onde não é mais interessante empreender e produzir. Nesse momento (KHALDUN, 1959, p. 95),

(...) o bem-estar e o luxo deixam de estender suas sombras benfazejas sobre os cortezões, os camareiros e os empregados civis; a carreira do fausto e da ostentação se estreita para eles assim como para o senhor do império.

Aqui surge o primeiro ponto onde Ibn Khaldun procura encaixar o racionalismo de viés aristotélico com a religião corânica em sua obra. Ao mesmo tempo em que entende o trabalho como algo fundamental para o progresso de uma sociedade - tese criada em razão da utilização do método aristotélico de análise das sociedades -, o autor de Os Prolegômenos conclui ser inevitável que essa mesma sociedade acabe caminhando para dentro da vida luxuosa e para longe do espírito de asabiyyah. Assim, há aqui a primeira importante tentativa de enquadrar o pensamento racionalista da falsafa. Em um ponto temos a análise racional da formação e sofisticação da mão de obra, a qual descamba no comércio de luxo e morre sob o constante crescimento tributário produzido pela necessidade de aquisição desses mesmos bens de luxo; no outro, o fundo moral representado pela asabiyyah, ou seja, uma sociedade mais atenta às regras corânicas seria menos preocupada com suntuosidade e um governo menos dado ao luxo cobraria impostos menores (KHALDUN, 1959, p. 266). Logo, Ibn Khaldun utiliza a falsafa para abordar, compreender e explicar uma determinada questão da 
realidade - a valoração do trabalho -, mas aponta para a religião e o sentimento de asabiyyah como possíveis maneiras de superar essa questão e ampliar o tempo de existência de uma dinastia.

Também é importante apontar que ao vincular o trabalho ao progresso de uma determinada sociedade, Ibn Khaldun coloca os trabalhadores em um novo patamar: eles carregam, ao mesmo tempo, o progresso e a destruição de uma dinastia. Eles são, paradoxalmente, os formadores, mantenedores e destruidores da teia social. No mundo árabe desse período, "as dimensões intelectuais atribuídas ao trabalho deram a ele, por um lado, um valor espiritual e, por outro, um papel social e econômico" (SHATZMILLER, 1994, p. 397, tradução nossa), o que, por sua vez, indica que as sociedades muçulmanas retratadas por Ibn Khaldun estavam em um período de "transição econômica" (SHATZMILLER, 1994, p. 397, tradução nossa) que "vai de uma economia mais limitada para outra mais diversificada, mais produtiva e mais integrada" (SHATZMILLER, 1994, p. 399, tradução nossa).

Nesse sentido, as sociedades muçulmanas representadas pelo ciclos históricos khaldunianos são aquelas que "alcançaram a mudança da agricultura para manufatura, criando dimensões ocupacionais" (SHATZMILLER, 1994, p. 399, tradução nossa). Dentro desse quadro de sofisticação na produção, a mais óbvia mudança "foi o crescimento nas dimensões da força de trabalho" (SHATZMILLER, 1994, p. 399, tradução nossa) e sua importância social.

Ao tornar o trabalho um dos alicerces de sua teoria, Ibn Khaldun não deixa de se colocar na origem do pensamento econômico moderno. Sua obra, ao ressaltar os benefícios do trabalho e sua conexão com os avanços de uma sociedade, dá "novas dimensões ao trabalho, todas positivas" (SHATZMILLER, 1994, p. 402, tradução nossa). Tal visão sobre esse tema, por sua vez, é indicador a respeito do novo status social conferido aos trabalhadores nas sociedades muçulmanas, a qual é muito diferente da antiga visão grega e mais positiva do que a da Europa medieval (SHATZMILLER, 1994, p. 402).

Ibn Khaldun tinha em mente um modelo econômico onde os agentes só prosperam quando seu trabalho é valorado de maneira correta, isto é, quando há 
correção na relação entre o trabalho e o quanto ele deve valer ${ }^{49}$. A partir da correção dessa relação surge o trabalho como formador de capital em economias orientadas para o mercado (RODINSON, 1973, p. 29-34) no mundo muçulmano da época de Os Prolegômenos.

Ibn Khaldun analisa o funcionamento de uma sociedade formada por tecelões, ferreiros, carpinteiros etc. Nela, esses profissionais acabam gerando uma rede de relações sociais. Por exemplo, os carpinteiros estão ligados à produção de madeira (KHALDUN, 1959, p. 332-334); os ferreiros, à mineração; e os tecelões, à criação de ovelhas (KHALDUN, 1959, p. 335-336). Também a sofisticação "das artes e a sua extensão dependem do número de pessoas que procuram seus produtos" (KHALDUN, 1959, p. 319). Logo, cria-se uma teia social que, quanto mais produtiva for, mais coesão vai gerar e necessitar. Em função disso, Ibn Khaldun entende que as relações humanas e as sociedades são profundamente moldadas pelo e para o trabalho, o qual atua como o mecanismo que necessariamente será responsável pela ascensão e derrocada de uma sociedade. Para ele, o "homem estende sua mão com autoridade sobre o mundo" (KHALDUN, 1959, p. 278) e "por meio de seu próprio trabalho e tendo em vista o lucro que o homem chega à aquisição" (KHALDUN, 1959, p. 279).

Enquanto a asabiyyah é o que aproxima um grupo dos preceitos corânicos, da autossuficiência e da correção moral. O trabalho, por sua vez, permite que uma sociedade prospere, se sofistique e produza grandes obras e um comércio de bens de luxo - "sem o trabalho, nada se adquire" (KHALDUN, 1959, p. 280). No entanto, ao fazer isso, o trabalho, que é central na construção de uma sociedade segundo Ibn Khaldun, afasta o grupo social da antiga autossuficiência e da correção moral presente nos povos nômades (badawi). Para ele, "a gente do campo é mais inclinada à virtude que os habitantes das cidades" (KHALDUN, 1958, p. 210). O resultado do crescimento urbano é a degradação moral do indivíduo comum, que perde sua autonomia ao se tornar altamente dependente dos trabalhos oferecidos por seus concidadãos (hadari), e dos poderosos, que para manter uma vida cada vez mais luxuosa, aumentam de maneira

\footnotetext{
${ }^{49}$ Segundo Le Goff, o "salário tem sido apresentado frequentemente como um dos principais elementos destruidores do sistema feudal" (A Idade Média e o dinheiro, 2010). Desde 1260, a Europa é palco de greves por melhores salários e há um esforço contínuo por parte das autoridades para que os salários não se alterassem ou então que eles retornassem aos patamares de 1348, período anterior à peste negra e a depressão demográfica provocada pela doença. Conforme apontou Bronislaw Geremek (Le Salariat dans l'artisanat parisien aux XXIe - XVe siècles, 1969), a introdução do salário no mercado de trabalho no meio urbano de Paris ocorreu no fim Idade Média. Nesse sentido, é possível perceber a diferença segundo a qual o trabalho era compreendido no islã e no mundo cristão.
} 
abusiva a cobrança de impostos (KHALDUN, 1959, p. 89). Assim, o trabalho em Os Prolegômenos resulta em algo intrinsicamente ligado aos aspectos efêmeros e transitórios da realidade, repetindo-se em um ciclo de virtude (badawi) e corrupção (hadari), o que, por sua vez, reforça o poder do perene e do imutável presentes no texto corânico, onde não há essa variação.

Outro fator importante que a obra de Ibn Khaldun revela é a organização econômica das sociedades muçulmanas entre os séculos XIII, XIV e começo do XV, as quais, em razão da maneira pela qual encaravam o trabalho, produziram dentro de si uma configuração comercial e financeira - espécie de pré-economia de mercado que caminha para uma economia moeda-mercadoria - (SHATZMILLER, 1994, p. 402) que só vai ter similar em complexidade e abrangência na Renascença italiana, após o surgimento dos primeiros sistemas bancários europeus. 


\subsection{ASABIYYAH}

Ibn Khaldun vê nas metrópoles o ambiente mais propício para o desenvolvimento do conhecimento, pois, segundo ele, a "civilização da vida sedentária marca o mais alto grau de progresso que um povo pode alcançar” (KHALDUN, 1959, p. 440). Porém, contraditoriamente, o mesmo autor encontra na asabiyyah, uma espécie de fortitude moral da sociedade muçulmana, nas populações nômades que vivem no deserto.

Asabiyyah é um termo muito utilizado em Os Prolegômenos. Os tradutores acabaram vertendo essa palavra para conceitos como "espírito de grupo", "sentimento tribal" ou "sentimento de grupo". Para Ibn Khaldun, ela ocupa o papel de principal matéria-prima na construção de grandes impérios. Segundo o autor, o nomadismo é o primeiro passo de um império simplesmente porque as sociedades começam em estágios que precedem as cidades. Segundo ele, a vida nômade "é um fato social perfeitamente natural" (KHALDUN, 1958, p. 205) e anterior à cidade (KHALDUN, 1958, p. 204). Novamente a regra aqui vai do mais simples para o mais complexo. É nesse percurso que ganha força e depois definha a asabiyyah (o espírito de grupo). É ela que vai levar um determinado povo a se estabelecer e se tornar poderoso.

Também reside nessa condição o surgimento de um líder. Portanto, Ibn Khaldun vincula o surgimento dos grandes impérios à necessidade de união que é intrínseca aos homens ${ }^{50}$, à fortitude moral de um povo e ao inevitável surgimento de um líder. Segundo o autor de Os Prolegômenos (KHALDUN, 1958, p. 243)

\footnotetext{
${ }^{50}$ Aqui há uma imensa semelhança entre o texto de Ibn Khaldun e duas possíveis fontes clássicas. A primeira é autor árabe é Aristóteles, o qual afirma que “(...) o homem é um ser político e está em sua natureza o viver em sociedade. Por isso, mesmo o homem bom viverá em companhia de outros, visto possuir ele as coisas que são boas por natureza. E, evidentemente, é melhor passar os seus dias com amigos e homens bons do que com estranhos ou a primeira pessoa que apareça. Logo, o homem feliz necessita de amigos" (ARISTÓTELES, 1991, p. 212); a segunda, mais difícil de ser confirmada, é Cícero, o qual afirma que "(...)o povo não é um aglomerado qualquer de seres humanos reunidos de uma forma qualquer, mas a reunião de pessoas associadas por um acordo em relação à justiça e a uma parceria para o bem comum. A primeira causa de tal associação não é a fraqueza do indivíduo, mas um certo espirito social que a natureza implantou no homem" (CICERO, 1928, p. 65, tradução nossa). No entanto, sabemos que o texto de Ibn Khaldun representa a aquisição indireta dessas formas de pensar. O autor de Os Prolegômenos teve acesso aos pensamentos grego e latino em textos árabes, nos quais a perspectiva dessas ideias entra no tecido do texto de Ibn Khaldun sem que isso seja uma citação direta ou que determinada obra tenha sido consultada. O que queremos apontar aqui é a continuidade dessas formas de pensamentos e certo "sotaque" árabe que os pensadores muçulmanos deram a elas.
} 
Qualquer sociedade de homens tem necessidade de um chefe para manter nela a ordem e impedir que uns agridam os outros. A premência que de um tal moderador resulta da própria natureza da espécie humana. Este chefe deve ter um partido forte em que se apoie; do contrário, faltar-lhe-ia a força para dominar os espíritos. O poder que exerce a soberania, autoridade muito superior à de um chefe de tribo, não possuindo este senão força moral, pode convencer os seus a acompanhá-lo, mas não tem o poder de constrangê-los a executar suas ordens. O soberano domina seus súditos e os obriga a respeitarlhe as vontades pela força que dispõe.

Enquanto na vida tribal dos beduínos a asabiyyah torna os clãs mais preparados para uma vida mais independente e movida pela eficiência, ela produz neles uma ligação mais profunda com a religião, já que os "nômades e a gente do campo são menos corrompidos que os habitantes da cidade" (KHALDUN, 1958, p. 209). No mundo civilizado, os soberanos acabam mergulhando no luxo e o povo perde sua autossuficiência. Aqui reside um dos ataques que o autor faz à vida urbana, onde os indivíduos, segundo ele, estão "ocupados habitualmente com seus prazeres e entregues aos hábitos do luxo, procuram os bens desse mundo transitório e abandonam-se às paixões" (KHALDUN, 1958, p. 209). Para ele, diferentemente dos povos nômades, as pessoas que vivem nas grandes cidades acabam se tornando menos independentes, distantes da religião e mais acostumadas à vida suntuosa. Isso as enfraquece e abre caminho para a decadência social.

Há portanto uma chave moral na compreensão socioeconômica de Ibn Khaldun. Para ele, quanto menos o atemporal representado pela religião estiver fora de uma sociedade, mas próxima ela fica daquilo que é mundano e fadado à corrupção.

Quatro gerações, segundo Ibn Khaldun, é o tempo suficiente para que uma dinastia surgida de uma tribo de beduínos se distancie do sentimento da asabiyyah (KHALDUN, 1958, p. 236-238). Assim, no momento em que chegam ao poder, os líderes tribais tendem a ser mais justos e zelosos. Eles cobram menos impostos e têm uma relação mais próxima com a população comum. Algumas gerações depois, os descendentes desses líderes, já acostumados à vida luxuosa das grandes cidades, acabam entendendo o poder como algo que lhes pertence por direito e passam a viver uma existência sem esforços baseada em aumentos constantes de impostos (KHALDUN, 1958, p. 245).

Ibn Khadun defende que as primeiras gerações de líderes são mais sóbrias, justas e austeras enquanto as últimas são preguiçosas e dadas aos vícios. Isso ocorre porque a vida do deserto torna o espírito do beduíno mais propício à maximização de seus 
interesses e à autossuficiência e à proximidade com a religião. $\mathrm{O}$ grupo que vive assim pensa e age de maneira mais global e eficiente. Essa asabiyyah, ou "solidariedade tribal", leva seus membros a se sacrificarem pelo grupo mais do que os moradores citadinos (KHALDUN, 1958, p. 272-279). Para Ibn Khaldun, esse sentimento torna os indivíduos das tribos do deserto mais virtuosos, uma vez que eles "são mais corajosos que os que moram nas cidades" (KHALDUN, 1958, p. 213). Nesse sentido, quanto maior for a presença da asabiyyah em uma sociedade mais justa será a política fiscal nela praticada e mais independentes serão seus indivíduos ${ }^{51}$.

Como já dissemos, para Ibn Khaldun, o progresso engendrado pelas grandes cidades afasta seus habitantes da asabiyyah, isto é, torna a sociedade menos solidária. "Nesse contexto de perda de valores, a necessidade de gastos cada vez maiores encoraja a corrupção" (LIZANA, 2006, p. 232). A produção nas grandes cidades carrega em si essa contradição: ao transformar inúmeras profissões cada vez mais dependentes umas das outras em razão da especialização da mão de obra, as grandes cidades são locais onde aos poucos seus líderes e seus habitantes vão se afastando da asabiyyah. Assim, a força coletiva que produziu aquela civilização se esfarela levando com ela a cidade. Nesse sentido Ibn Khaldun mostra todo seu pessimismo. Ele não crê na possibilidade de uma grande cidade tomada pelo "sentimento de grupo", pela asabiyyah, ao contrário, para ele, a vida citadina leva os indivíduos a dizerem "obscenidades" (KHALDUN, 1958, p. 209) e a adotarem "uma conduta descarada" (KHALDUN, 1958, p. 209), tornando-os "impermeáveis a qualquer sentimento de modéstia ou de pudor" (KHALDUN, 1958, p. 210). Sua análise baseia-se na tese de que ao se desenvolver uma cidade vai invariavelmente se afastar da correção moral dos seus primeiros líderes. Para Ibn Khaldun, o progresso gera o luxo que degenera os homens, principalmente os

\footnotetext{
${ }^{51}$ É nesse ponto que muitos economistas conservadores se aproximam das teorias econômicas de Ibn Khaldun. O economista Arthur Laffer, mentor intelectual da política fiscal do presidente norte-americano Ronald Reagan, citava Ibn Khaldun quando falava da relação entre arrecadação e produção (Curva de Laffer). Para esses economistas, Ibn Khaldun acerta ao dizer que quando um governo aumenta sua arrecadação ele corre o risco de diminuir o empreendedorismo. Segundo Ibn Khaldun, quando um governo está mais próximo da asabiyyah, ele é visto com mais respeito por seus súditos, que aproveitam esse ambiente propício e seguro para produzir e ganhar mais. Ibn Khaldun sabia, no entanto, que nenhuma civilização humana existe sem tributação, o problema, para ele, era encontrar a justa medida, ou seja, não cobrar mais nem menos impostos do que o necessário. De certa forma, sua análise apresenta a possibilidade de uma sociedade atingir um "ponto de equilíbrio" fiscal capaz de manter uma economia pujante durante um período de tempo maior que o normal. A manutenção de uma sociedade em seu auge econômico, por sua vez, estaria ligada à capacidade dessa mesma sociedade em manter-se próxima da asabiyyah.
} 
líderes, os quais passam a cobrar cada vez mais impostos para manter suas vidas suntuosas. Sua visão da história é, portanto, cíclica e de moral rígida ${ }^{52}$.

De certa forma, asabiyyah em Os Prolegômenos exerce um papel parecido ao conceito de felicidade sa 'ada presente na obra de Al-Fārābī (CRAIG, 1998, p. 557). A diferença é que no primeiro, asabiyyah é algo quase que organicamente ligado a determinados grupos, é algo inerente à vida nômade ou de pequenas comunidades (KHALDUN, 1958, p. 220-221). Porém, é o principal mecanismo na constituição de uma sociedade mais complexa e de uma vida mais correta. Já o sa'ada é a suprema felicidade. Ela só poderia ser atingida por aqueles (Estado ou indivíduos) que levam uma vida virtuosa voltada para a imagem de Deus. Para Al-Fārābī, todo regime político deveria servir a esse propósito. Ele acredita que um Estado ideal seria algo extremamente hierarquizado, com um governante supremo capaz de sempre tomar decisões que levam a população à sa'ada. Em razão disso, Al-Fārābī aponta para a "solução platônica do rei-filósofo apresentada na República", segundo Miguel Attie Filho (2002, p. 200), adaptando-a à figura de um califa ideal, que atingiu o mais alto nível de felicidade humana e assim se tornou capaz de conduzir religiosa e politicamente um povo. Porém, Al-Fārābī afirma que essa cidade ideal é, de certa forma, inatingível caso não surja entre seus habitantes o rei-filósofo. Essa constatação aponta para uma diferença entre a cidade ideal e as cidades reais. Para Al-Fārābī, os regimes que majoritariamente existem são aqueles nos quais a população (ATTIE FILHO, 2002, p. 223)

busca por outros bens que não levam seus habitantes à felicidade, buscam por riqueza ou fortuna; honrarias e vaidade; cidades que valorizam as disputas com outras; cidades que falseiam a felicidade.

Assim, Al-Fārābī e Ibn Khaldun, cada um a seu modo, determinam que um conceito primordial (sa'ada e asabiyyah) deve ser o principal guia para a condução correta de uma cidade. Ambos, no entanto, creditam mais votos ao fracasso dessa busca do que à sua realização. Há em ambos um pessimismo quanto à capacidade das cidades em perpetuar ou mesmo atingir esse momento de constante prosperidade. Porém, no

\footnotetext{
${ }^{52}$ Há em Ibn Khaldun um viés moralista que mito se assemelha ao tratamento que John Ruskin dava à produção e ao consumo de bens de luxo. Para Ruskin, segundo afirma o historiador e tradutor Rafael Cardoso na introdução da obra A economia politica da Arte, "o consumo de mercadorias de luxo e, por extensão, a então nascente indústria da moda, são necessariamente responsáveis pela degradação e morte de muitos seres humanos" (RUSKIN, 2004, p. 15).
} 
caso de Ibn Khaldun, "a própria prescrição divina conforma-se (...) com as propriedades naturais da civilização" (AL-JABRI, 1999, p. 154). 


\title{
2.4 MÃO DE OBRA
}

Para Ibn Khaldun, o motor da sofisticação da mão de obra é o lucro e a capacidade de aumentar as possiblidades de troca. Em Os Prolegômenos ele afirma que (KHALDUN, 1959, p. 280):

(...) se as mercadorias das quais se retira proveito ou vantagem forem produto de uma arte especial, esta vantagem e este proveito representam o preço do trabalho do operário ou do artífice, e é isto o que se designa pelo termo de lucro (...) existem certas artes que compreendem em si outros ofícios: o de carpinteiro, por exemplo, está ligado ao de marceneiro, e a arte do tecelão acompanha a de fiação. Mas há mais mão de obra no ofício de marceneiro e no de tecelão, o que faz que o trabalho deles deva ser melhor remunerado.

O autor também acredita que a maior oferta de mão de obra ajuda a elevar o piso salarial. Portanto, para ele, é o tamanho do mercado de trabalho e seu grau de especialização que determinam o nível dos salários (KHALDUN, 1959, p. 315-316).

\begin{abstract}
Quando a cidade está em plena efervescência de prosperidade, estes ofícios terão feito tanto progresso que fornecem a maior parte dos objetos que são necessários ao bem-estar dos habitantes, e, em consequência dos encorajamentos extraordinários que recebem, tornam-se meios regulares de subsistência para as pessoas que os exercem. Novas artes vem se acrescentando às primeiras, cujo florescimento é provocado pelo luxo avassalante da cidade. Encontram-se pintores (ou perfumistas), trabalhadores em cobre, banhistas, cozinheiros, fabricantes de esponjas, vendedores de heriça, mestres que ensinam o canto, a dança e a arte de bater tamborim com ritmo. Acrescenta-se os livreiros, cujo trabalho consiste em transcrever livros, encaderná-los e corrigi-los, porque isto também é uma arte nascida do luxo das cidades, quando nelas se ocupa de coisas intelectuais.
\end{abstract}

Se um mercado é grande o suficiente para ter mais demanda que oferta, isso levará trabalhadores como marceneiros a ganharem mais porque, segundo Ibn Khaldun, haverá uma disputa entre os compradores para a obtenção do "produto de trabalho; o resultado disso é que operários e artífices tornam-se muito exigentes impondo um alto preço a seus serviços" (KHALDUN, 1959, p. 244). Isto é, quanto maior for a procura e mais qualificado e capaz de atender os luxos da vida sedentária (KHALDUN, 1959, p. 333) melhor deverá ser sua remuneração. Portanto, o tamanho de uma cidade determinará a oferta relativa de mão de obra com diferentes níveis de qualificação. Porém, ao mesmo tempo, o crescimento da cidade acaba promovendo um comércio que Ibn Khaldun acredita desnecessário e prejudicial: o comércio de luxo. Logo, a especialização da mão de obra e o aumento salarial que ela representa carregam em si o germe da destruição dessa mesma civilização.

Segundo Ibn Khaldun (1959, p. 316), quando a prosperidade atinge 
(...) seus extremos limites, o cultivo das artes ultrapassa todas as barreiras. Assim temos ouvido dizer que no Cairo havia certa gente que ensinava os pássaros a falar, adestrava burros em fazer habilidades, operava prodígios que iludem os olhares do espectadores, que ensinava cantar, dançar e andar sobre uma corda esticada no ar, que suspendia grossos animais e pesadas pedras, sem falar de outros ofícios que não existem entre nós na Mauritânia, por serem as cidades do nosso país inferiores em prosperidade à do Velho e do Novo Cairo.

Para o autor de Os Prolegômenos "a estabilidade e a duração das artes, numa cidade, dependem da estabilidade e da antiguidade de sua civilização" (KHALDUN, 1959, p. 316). Para ele, mesmo depois de um período de decadência, certas civilizações mantêm fortes traços de sua cultura, pois a mesma é um hábito que "se enraíza pela frequente repetição e longa duração" (KHALDUN, 1959, p. 316). Porém, em última instância, Ibn Khaldun aponta um motivo econômico para a manutenção da especialização e valoração da mão obra: "a melhoração das artes e sua extensão dependem do número de pessoas que procuram seus produtos" (KHALDUN, 1959, p. 316). Assim, é a lei da oferta e da demanda a principal responsável pela manutenção e pelo progresso das técnicas e dos conhecimentos de uma determinada região. Sem a demanda, o que fica são restos das artes que "floresceram em outras eras" (KHALDUN, 1959, p. 316).

Outro fator que Ibn Khaldun relaciona à evolução dos povos nômades para civilizações urbanas é o surgimento da noção de mão de obra como fonte de valor. $O$ primeiro momento que a obra de Ibn Khaldun trata da mão de obra sob esse ponto de vista ocorre no capítulo 27 do primeiro tomo da versão em português feita por José Khoury. Nesse trecho, o autor afirma (KHALDUN, 1959, p. 263):

\begin{abstract}
Ora, o exercício das artes e dos ofícios é a verdadeira fonte da riqueza, como demonstraremos mais tarde. Se as profissões manuais encontram empecilhos e deixam de ser protegidas e aproveitadas, perde-se a esperança do lucro e renuncia-se ao trabalho; a ordem estabelecida perturba-se e a civilização recua $^{53}$.
\end{abstract}

Segundo Ibn Khaldun, os salários variam de um lugar para o outro, até mesmo quando comparamos profissões idênticas em cidades diferentes. Isso ocorre em razão da capacidade do trabalho de aumentar a produtividade de uma região da demanda existente e da oferta relativa de mão de obra com diferentes níveis de qualificação. Ele, ao comparar as cidades de Fez e Tlemcen (KHALDUN, 1959, p. 240), indica que

\footnotetext{
${ }^{53} \mathrm{Na}$ tradução para o inglês, feita por Franz Rosenthal, é possível ler a seguinte versão: Now, as we shall mention, labor is the real basis of profit. When labor is not appreciated and is done for nothing, the hope for profit vanishes, and no (productive) work is done. The sedentary population disperses, and civilization decays (KHALDUN, 1967, p. 269).
} 
quanto maior a população de um local, maior é seu potencial produtivo ${ }^{54}$. Para Ibn Khaldun (1959, p. 247-248)

Nas regiões em que a prosperidade é geral, e cujas províncias contêm numerosas populações, vivem habitantes na abundância e possuem grandes riquezas. Numerosas ali são as cidades; os impérios e os reinos são muito poderosos. Tudo isso é resultado da abundância dos produtos da indústria (...) o bem-estar da população aumenta com o lucro, a abastança torna-se cada vez maior; as riquezas chegam depois, trazendo luxo atrás de si; a atividade do comércio aumenta o produto dos impostos, enriquecendo assim o governo (...) por exemplo, as regiões do Oriente como o Egito e a Síria, o Iraque pérsico, a Índia, a China, todos os Países do Norte e os que estão situados além do Mar de Rum (regiões da Europa). Como essas regiões estão bem povoadas, o dinheiro ali é abundante, seus impérios são poderosos, e suas cidades numerosas; o comércio é muito grande, assim como a abastança dos habitantes. Vêde os negociantes cristãos que, em nossos dias, vêm procurar os muçulmanos do Magrib: suas riquezas e seu modo de vida estão acima de toda descrição.

O conceito defendido por Ibn Khaldun de que quanto maior a população maiores serão as chances de obter lucro é algo que permeia a microeconomia contemporânea. Por exemplo, se analisarmos o seguinte gráfico:

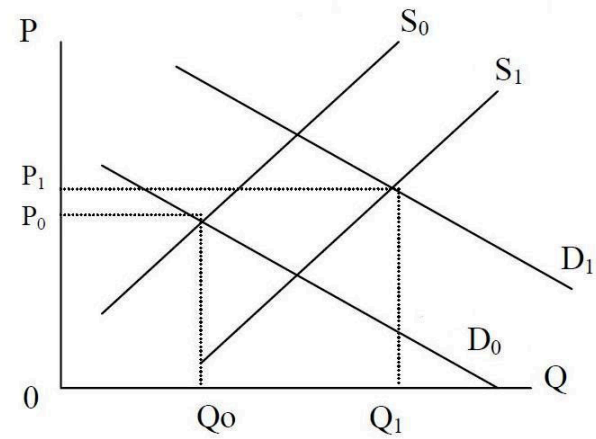

Fonte: Koutsoyiannis, Modern Microeconomics

Nele, podemos visualizar uma representação do conceito proposto por Ibn Khaldun, para o qual um aumento na demanda produz crescimento da oferta, dos preços e dos lucros. Segundo ele, quando a demanda cresce (vai de $\mathrm{D}_{0}$ para $\mathrm{D}_{1}$ ), em razão da procura produzida por grandes populações, o preço sobe (vai de $\mathrm{P}_{0}$ para $\mathrm{P}_{1}$ ) e a oferta também cresce (vai de $\mathrm{S}_{0}$ para $\mathrm{S}_{1}$ ). Portanto, conforme essa regra, quando a demanda por produtos supera a oferta, ocorrerá escassez; já se a oferta de produtos ultrapassara demanda, ocorrerá superávit. Nesse modelo, o preço e a quantidade de bens produzidos

\footnotetext{
${ }^{54}$ Séculos depois, autores como Adam Smith retomarão essa exata explicação quando analisarem a capacidade do mercado de trabalho. Para eles, quanto maior o mercado, maior é sua demanda, mesmo quando os preços e o custo da mão de obra são diferentes. Ibn Khaldun, por sua vez, percebe que uma sociedade maior permitirá maiores investimentos e também terá maior oferta. Apesar dos custos em uma cidade mais populosa serem maiores, esse mercado mais potente é capaz de gerar lucros maiores. Hoje, esse conceito faz parte de qualquer livro básico de microeconomia e muitos autores afirmam que essa teoria foi "criada" por Adam Smith, quando o mesmo comparou a capacidade produtiva da Inglaterra e outras regiões do mundo.
} 
são determinados pelo ponto de equilíbrio do mercado, isto é, o ponto onde a oferta atende à demanda e os interesses se equivalem. Nesse modelo, uma forte demanda só será vencida por uma sociedade capaz de aumentar consideravelmente sua produção. Para essas duas coisas acontecerem, demanda e produtividade altas, faz-se necessário, segundo Ibn Khaldun, uma região altamente povoada ${ }^{55}$.

A tese defendida por Ibn Khaldun é a seguinte: populações maiores serão sempre capazes de produzir mais e gerar regiões mais ricas e poderosas. Esse quadro social, segundo ele, também ajuda a ampliar os conhecimentos e sofisticar as ciências. Para o autor de Os Prolegômenos, "quanto mais numerosa for a população de uma cidade e quanto houver civilização e luxo, tanto mais se aperfeiçoam e se multiplicam as artes" (KHALDUN, 1959, p. 400).

Portanto, há no texto a noção de que a melhor qualificação dos trabalhadores é, ao mesmo tempo, requisito e resultado de uma economia mais pujante. Ele também "reconhece o papel exercido pela oferta e a demanda para determinar a renda, o status social e a performance de certos negócios" (SHATZMILLER, 1994, p. 395-396). Segundo Ibn Khaldun, um sistema complexo de produção só é possível com alto nível de cooperação entre os atores e grande especialização da mão de obra. Em razão disso, o texto de Os Prolegômenos indica que quanto mais sofisticados são os produtos de uma sociedade maior será a necessidade de ensinos técnicos para os seus trabalhadores. Dessa maneira, Ibn Khaldun infere uma vinculação entre a capacidade produtiva e a oferta de conhecimento. Conforme esse raciocínio, uma cidade que não oferece acesso fácil ao conhecimento não poderá aumentar sua capacidade produtiva. Para ele (KHALDUN, 1959, p. 400),

Se o nativo de uma vila ou de uma cidade, que não seja uma metrópole, é impelido por uma disposição natural a colher conhecimentos científicos, não achará no lugarejo os meio para sua instrução; pois o próprio ensino é uma arte, e as artes não existem para as pessoas do campo, como já mostrámos. Assim, pois, para se instruir, é preciso procurar uma grande cidade.

\footnotetext{
${ }^{55}$ Hoje, sabemos que o aumento da produtividade ocorre também em função da intensidade com que as inovações tecnológicas são inseridas no processo produtivo. Paradoxalmente, para Ibn Khaldun, o aperfeiçoamento e a multiplicação das artes não estão necessariamente ligadas ao aumento da produtividade. Segundo ele, elas surgem principalmente como fatores que vão tornar a vida urbana mais interdependente, complexa e que vão possibilitar, no momento em que uma determinada economia atinge seu auge, a produção de grandes obras. A produtividade, em Os Prolegômenos, está mais vinculada ao número de habitantes de uma região. Quanto maior for esse número, maior será a capacidade produtiva dessa sociedade.
} 
Ibn Khaldun aponta para os benefícios produzidos pela divisão do trabalho em ofícios cada vez mais complexos. O autor vê na especialização do trabalhador um poder civilizador. Ela é capaz não só de aumentar a produção, mas também de melhorar o padrão de vida de uma determinada população. Ibn Khaldun (1959, p. 400) indica que

Quando homens estabelecidos em sociedade podem, pelo seu trabalho, obter mais do que o suficiente para viver, dirigem seu olhar para uma finalidade mais afastada, e se ocupam de matérias que, como as ciências e as artes, pertencem mais intimamente à natureza humana ${ }^{56}$.

O texto khalduniano defende que o lucro e a abastança propiciam grandes metrópoles e suas sociedades do conhecimento. O sucesso dos negócios é capaz de fazer avançar as descobertas científicas, levar as pessoas a adotarem novos comportamentos sociais e reunir em grandes centros urbanos especialistas de várias áreas. Para Ibn Khaldun, quanto mais urbanizada é uma sociedade, maior será o contato dela com o conhecimento (KHALDUN, 1959, p. 400). Esse ciclo virtuoso movido pelo benefício (rizc) e o lucro (ku’nia) torna mais evidente a percepção de Ibn Khaldun, baseada na realidade, de que a competência de uma sociedade de mercado em alocar recursos de forma racional, satisfazer suas necessidades através da cooperação e desenvolver maneiras mais eficientes de produção ocorre em razão direta do seu domínio das artes e

\footnotetext{
${ }^{56}$ Séculos depois, em sua obra $A$ ideologia alemã, Karl Marx afirmaria: “com a divisão do trabalho, dá-se ao mesmo tempo a contradição entre o interesse dos indivíduos ou das famílias singulares e o interesse coletivo de todos os indivíduos que se relacionam mutuamente; e, sem dúvida, esse interesse coletivo não existe meramente na representação, como 'interesse geral', mas, antes, na realidade, como dependência recíproca dos indivíduos entre os quais o trabalho está dividido. E, finalmente, a divisão do trabalho nos oferece de pronto o primeiro exemplo de que, enquanto os homens se encontram na sociedade natural e, portanto, enquanto há a separação entre interesse particular e interesse comum, enquanto a atividade, por consequência, está dividida não de forma voluntária, mas de forma natural, a própria ação do homem torna-se um poder que lhe é estranho e que a ele é contraposto, um poder que subjuga o homem em vez de por este ser dominado. Logo que o trabalho começa a ser distribuído, cada um passa a ter um campo de atividade exclusivo e determinado, que lhe é imposto e ao qual não pode escapar; o indivíduo é caçador, pescador, pastor ou crítico, e assim deve permanecer se não quiser perder seu meio de vida - ao passo que, na sociedade comunista, onde cada um não tem um campo de atividade exclusivo, mas pode aperfeiçoar-se em todos os ramos que lhe agradam, a sociedade regula a produção geral e me confere, assim, a possibilidade de hoje fazer isto, amanhã aquilo, de caçar pela manhã, pescar à tarde, à noite dedicar-me à criação de gado, criticar após o jantar, exatamente de acordo com a minha vontade, sem que eu jamais me torne caçador, pescador, pastor ou crítico" (MARX; ENGELS, p. 37-38, 2007). Portanto, para Marx, a divisão do trabalho retira dos indivíduos suas liberdades, pois ela os torna presos a profissões cada vez mais específicas. Logo, ele acreditava que a divisão do trabalho alienava as pessoas de sua humanidade. A superação desse quadro, segundo ele, só surgiria se tal divisão fosse superada pela "sociedade comunista". Já Ibn Khaldun indica que uma sociedade com ampla divisão do trabalho produz especializações e conhecimentos que, por sua vez, resultam em abundância e permitem certas liberdades aos seus indivíduos, os quais, nesse momento, podem se ocupar com assuntos como "ciências e artes". Nesse sentido, Ibn Khaldun, ao contrário de Marx, vê nessas sociedades economicamente mais desenvolvidas um perigoso e crescente distanciamento da fortitude moral representada pela asabiyyah, com a qual os indivíduos só se reconciliam profundamente quando vivem sob um certo tribalismo nômade autossuficiente, moralmente mais nobre, porém, economicamente menos desenvolvido.
} 
do conhecimento, em um exemplo claro de como o racionalismo pode levar uma sociedade a funcionar (LIZANA, 2006, p. 230).

Ibn Khaldun também aponta que grandes centros urbanos produzem conhecimento, no entanto, esse mecanismo é o mesmo que afasta essa civilização do sentimento de asabiyyah. Segundo sua tese (KHALDUN, 1959, p. 260),

\begin{abstract}
Um povo que se acha na abundância se deixa levar naturalmente por todos os usos da vida sedentária, adotando todos seus caracteres e modos. Ora, nesta modalidade de existência dos civilizados sedentários, a Civilização consiste na introdução de todos os gêneros de luxo, na procura do que há de melhor, e no afã de cultivar as diversas artes: por exemplo, o que se inventou para o aperfeiçoamento da cozinha, a confecção de vestimentas, dos edifícios, dos utensílios e de todas as outras coisas que figuram na economia de uma casas
\end{abstract}

Nesse sentido, é possível perceber certo anti-intelectualismo e censura à vida civilizada permear Os Prolegômenos, obra que vê no progresso a negação de uma sociedade mais próxima do Alcorão. As grandes cidades, com seu comércio de luxo, são o oposto à vida simples dos povos nômades do deserto. Para Ibn Khaldun, esses dois mundos são incompatíveis. Em um, o nômade, os indivíduos são nobres e autossuficientes; no outro, o sedentário, as pessoas acabam fadadas à dependência generalizada e ao vício da suntuosidade, da futilidade e do supérfluo (KHALDUN, 1959, p. 260-265).

Ibn Khaldun constata nessa aparente contradição o perfeito cenário para sua tese. Para ele, encontramos na vida nômade os embriões da civilização: a asabiyyah, a determinação, a autossuficiência, a fortitude moral e a proximidade com a religião. São exatamente esses aspectos que vão levar uma sociedade a se desenvolver. Todavia, o resultado desse desenvolvimento carrega em si a inequívoca decadência desse mesmo grupo (KHALDUN, 1958, p. 230-234). Tal característica, presente nos povos que se destacam e formam grandes dinastias, contrapõe a qualidade do efêmero intrínseco à vida em sociedade ao caráter perene presente no mundo divino e no texto sagrado, o qual é "fundamento para todos os conhecimentos" (KHALDUN, 1960, p. 278). Assim, temos em Ibn Khaldun uma análise racionalista e aristotélica daquilo que é humano, isto é, o trabalho e a sociedade - esta última sempre fadada à imperfeição. Ao mesmo tempo, ele apresenta caminhando pari passu uma resposta teológica e as prescrições morais que a exposição dessa análise encerra. O resultado desse encontro é a 
combinação da compreensão pessimista de uma realidade social cíclica ${ }^{57}$ e trágica que tende à inexorável regra: surgimento, expansão, auge e corrupção.

\footnotetext{
${ }^{57}$ Há no texto a descrição de uma sequência de fenômenos econômicos que respondem à expansão e à contração socioeconômica de uma determinada sociedade. Para Ibn Khaldun, o fator que produz tais ciclos é fundamentalmente endógeno, isto é, ele resulta da presença ou não da asabiyyah nessa sociedade. É importante notar que Ibn Khaldun não desconsidera completamente os fatores exógenos (pestes, invasões etc.), porém, ele os coloca claramente em segundo plano.
} 


\title{
2.5 OFERTA E DEMANDA E PRESSÃO INFLACIONÁRIA
}

As práticas comerciais e a busca pelo lucro defendidas por Ibn Khaldun não estão isentas de problemas. O texto aponta, por exemplo, que oferta e demanda são responsáveis por aumentar ou diminuir o valor dos produtos e com isso impulsionar o desenvolvimento de uma determinada região. No capítulo Do preço (dos gêneros e das mercadorias) nas cidades, Ibn Khaldun (1959, p. 243) explica que quanto maior for a procura, tanto de artigos de "primeira necessidade" como de "artigos de luxo", maior será a competição para produzi-los. Segundo ele, quando os compradores são numerosos, os produtos acabam tornando-se escassos, o que, por sua vez, produz "concorrência". Porém, em um primeiro momento, o que teremos será "carestia" (KHALDUN, 1959, p. 243-246) - em um exemplo claro de descrição do mecanismo de pressão inflacionária. Já em cidades menores, onde a produção e a oferta não são tão grandes, os preços tendem a ser maiores pois os moradores, com medo de ficarem sem os gêneros de primeira necessidade e, em razão disso, sofrer com a fome, praticam um acúmulo desmesurado de tais produtos. As pessoas preferem comprar muito mais do que necessitam e isso acaba produzindo a manutenção dos preços altos (KHALDUN, 1959, p. 244). De qualquer forma, ele entende que a incidência de aumentos generalizados em produtos leva à redução do poder de compra, ou seja, a pressão inflacionária ocorre ou pela aquisição exagerada de produtos nas cidades menores ou pelo crescimento na demanda nas grandes cidades - em ambos casos, tais descrições são muito próximas, quando não são idênticas, ao que a economia atual entende por inflação puxada pela demanda (WELCH; WELCH, 2016, p. 117) ${ }^{58}$.

Ibn Khaldun faz inclusive a análise da alta de preços em al-Andaluz. Segundo ele (KHALDUN, 1959, p. 245):

\begin{abstract}
Os habitantes desse país, depois de terem deixado de tirar as suas boas terras e suas províncias pelos cristãos, se viram rechaçados para o litoral e confinados em regiões muito acidentadas, impróprias para a agricultura e pouco favoráveis à vegetação. Se viram obrigados a dispender muitos cuidados para o cultivo das terra para poderem obter colheitas suficientes. Os trabalhos dessa natureza exigem muitos gastos e necessitam diversos acessórios, alguns dos quais, por exemplo, o esterco, são de custo elevado. Os fretes de cultura são, pois, muito altos entre os Muçulmanos de Espanha e são calculados necessariamente no preço da venda. Eis porque há carestia nesta parte do território espanhol.
\end{abstract}

\footnotetext{
${ }^{58} \mathrm{O}$ que indica e reforça a tese de que a obra de Ibn Khaldun nos obriga a uma compreensão mais elástica da história do pensamento econômico.
} 
Em Os Prolegômenos há portanto os conceitos claros de oferta, demanda e pressão inflacionária, os quais são resultado direto do tamanho da cidade, do custo dos insumos e das características geomorfológicas da área na qual ela está localizada. Ibn Khaldun também volta aos gregos - e não à tradição judaico-cristã - quando fala de $\operatorname{preços}^{59}$.

Ibn Khaldun, seguindo certo vocabulário filosófico de fundo aristotélico, acredita que o comércio e, portanto, a política de preços surgem apenas nas grandes cidades, movimento que também alimenta e incrementa o comércio e o número de pessoas envolvidas nele. Segundo ele, "é guardando um justo meio nas suas operações e aproveitando das rápidas flutuações que ocorrem no curso do mercado que esta classe de homens realiza benefícios e ganha sua vida" (KHALDUN, 1959, p. 312). Dessa forma, o autor lança as fundações daquilo que a teoria econômica acabaria posteriormente tratando por disequilibrium analysis (ATIYEH; OWEISS, 1988, p. 118).

Segundo essa teoria, a variação da oferta ou da demanda sempre produz mudanças nos preços (desequilíbrio), os quais vão se reconfigurar até atingir um novo ponto de equilíbrio $^{60}$.

Para Ibn Khaldun, há uma relação profunda entre os preços, os custos da produção e a estocagem. Ele afirma que os habitantes das cidades sabem que é possível estocar cereais até que os mesmos "se tornem caros" (KHALDUN, 1959, p. 310). Segundo ele, essa operação é "lesiva" porque a "excessiva carestia das mercadorias" é capaz de prejudicar "gravemente os interesses dos que fazem dele um ramo de negócio" (KHALDUN, 1959, p. 311). Portanto, para o autor de Os Prolegômenos, quando ocorre um excesso de estoque de uma determinada mercadoria, o resultado é que a cadeia produtiva relacionada àquele produto seja prejudicada. Da mesma forma, quando os

\footnotetext{
${ }^{59}$ Nesse ponto Ibn Khaldun, apesar de não ter lido a Política de Aristóteles chega a conclusões muito similares às do texto grego. A concepção de preços de Ibn Khaldun em muito se assemelha à noção aristotélica de preços presentes na Política (ARISTÓTELES, 2002, p. 23) - na marcação da mesma obra de Aristóteles em inglês, esse trecho se refere à passagem 1256b40-1258a20. Portanto, é possível dizer que Ibn Khaldun novamente produz um texto que apresenta certa fidelidade à terminologia aristotélica. Segundo o filósofo grego, a forma mais natural das coisas de organização econômica é aquela baseada na troca, "expediente necessário para proporcionar a cada um a satisfação de suas necessidades" (ARISTÓTELES, 2002, p. 23).

${ }^{60}$ Curiosamente, Ibn Khaldun trabalha de forma concomitante com uma teoria que séculos depois acabaria se tornando progressista - a teoria baseada no conceito de valor-trabalho - e uma outra mais conservadora, e também muito posterior aos Prolegômenos, fundamentada por um conceito de utilidade marginal, que se restringe em muito à determinação, no curto prazo, comandada exclusivamente pela lei de oferta e procura. Em seu texto, portanto, podemos encontrar tanto as bases para um pensamento econômico de esquerda como para um pensamento econômico liberal e pró mercado.
} 
preços permanecem, durante muito tempo, demasiadamente baixos, a cadeia produtiva também é afetada. Segundo ele (KHALDUN, 1959, p. 312),

(...) quando os cereais quedam muito tempo com preços baixos. Os indivíduos que cuidam da lavoura e outros ofícios similares dependendo da produção de cereais padecem na sua fortuna. Ganham pouco ou nada, e não veem aumentar seu capital; ou então, achando insuficiente o proveito, tomam o hábito de emprestar de seu capital o que precisam para sua subsistência. A mesma depreciação lesa depois aos moleiros, aos padeiros e a todos os que se ocupam dos ofícios que têm por base grãos, desde o momento de os semear até o de serem convertido em alimento.

Portanto, podemos afirmar que os efeitos de problemas como inflação, fome, carestia e a força da oferta e da demanda são todos fenômenos muito evidentes para Ibn Khaldun. Ele não só os percebe como indica quais seriam as possíveis soluções, apontando para políticas fiscais (KHALDUN, 1959, p. 24, 89 e 143), gastos governamentais (KHALDUN, 1959, p. 89) e criticando o intervencionismo estatal (KHALDUN, 1959, p. 91-94). Segundo ele, os governantes agem corretamente quando são mais atentos à lei corânica, isto é, quando "vivem numa honesta simplicidade para não se expor à troça e ao ridículo" (KHALDUN, 1959, p. 272). Nesse sentido, a obra Os Prolegômenos representa uma importante contribuição ao pensamento econômico e à teoria sobre taxação e à intervenção estatal na economia. Um governo que taxa de maneira correta, ou seja, que não sobretaxa para manter uma vida de luxo distante dos ideias religiosos, está mais propício a produzir uma sociedade economicamente mais vibrante (KHALDUN, 1959, p. 87-89). Da mesma forma, um governo que interfere na atividade econômica comete "erro grave e prejudicial (...) aos interesses do povo" (KHALDUN, 1959, p. 91). Novamente, Ibn Khaldun encontra a solução para o impasse dos preços na observação dos preceitos religiosos pelos governantes e pelo respeito ao texto corânico, ao encerrar o debate sobre tais temas com frases como: "Que Allah nos inspire para nos orientarmos e que nos faça gozar dos frutos de nossas boas ações; não há outro senhor fora Ele" (KHALDUN, 1959, p. 94) e "Allah regula as vicissitudes das noites e dos dias" (KHALDUN, 1959, p. 246). 


\subsection{DIVISÃO DO TRABALHO}

Em Os Prolegômenos é possível ver que o uso racional dos meios de produção se dá pela intensa divisão do trabalho. Segundo Ibn Khaldun, há dois grupos principais de ocupações (KHALDUN, 1959, p. 282):

(...) o da primeira espécie se pratica somente sobre uma matéria especial, e leva o nome de arte; entra nessa categoria, por exemplo, a escrita, a marcenaria, a arte do alfaiate, do tecelão, e do escudeiro. O trabalho da segunda espécie não se restringe a uma matéria especial, mas consiste nas diversas ocupações laboriosas de um homem de trabalho.

Há aqui uma evidente hierarquização. Ibn Khaldun separa a mão de obra em trabalhadores mais e menos qualificados. No entanto, para ele isso não significava a superioridade do trabalho do primeiro tipo. Novamente, Ibn Khadun aponta para a vida mais simples como algo moralmente superior à vida de luxo das grandes cidades. $\mathrm{O}$ autor, apesar de afirmar que o trabalho mais qualificado será também o mais bem pago, entende que os ofícios comuns, principalmente a agricultura, são dotados de "uma superioridade intrínseca sobre os demais" (KHALDUN, 1959, p. 283). Isso ocorre por duas razões, uma delas lógica, explicar tudo partindo do simples para o complexo; outra religiosa, há mais valor moral nas atividades rurais, pois estas são mais básicas e destarte mais importantes para a manutenção da vida. O autor de Os Prolegômenos aponta que a agricultura (KHALDUN, 1959, p. 282),

Por ser fácil, natural, e de acordo com a disposição inata do homem; não exige nem estudos, nem ciência, e por esta razão, o povo dá-lhe por inventor Adão, o pai da espécie humana. 'Foi ele, dizem, o primeiro a ensiná-la e a praticá-la.' Por estas palavras querem deixar entender que ela é o mais antigo meio e o mais natural de procurar subsistência. As artes vêm em segundo lugar, depois da agricultura. Tornando-se complicadas e devendo ser aprendidas e praticadas, exigem o emprego da reflexão e da atenção. É o motivo por que as artes não florescem habitualmente senão na vida sedentária, modo de existência precedido pelo da vida nômada. Foi pela mesma razão que se atribuiu a invenção das artes a Idris ${ }^{61}$, segundo pai dos mortais, o qual, dirigido por uma inspiração divina, as tinha inventado para uso de sua posteridade. O comércio, considerado como meio de ganhar a vida, é conforme a natureza, embora, na maior parte das operações, consista ele em golpes de astúcia empregados com o fim de se estabelecer entre o preço de compra e o preço de venda uma diferença que dê margem ao lucro.

Nesse ponto, a tradução de José Khoury indica que a agriculta é superior (pois está em primeiro lugar) e que a astúcia do comerciante seria a responsável pela

\footnotetext{
${ }^{61}$ Idris, segundo a religião muçulmana, é, assim como Enoch para judeus, o criador de todas as artes, uma espécie de criador da cultura e dos conhecimentos. Teria sido ele, de acordo com essas tradições, o inventor da escrita.
} 
conquista do "lucro". Já na tradução para o inglês, feita por Franz Rosenthal (1967, p. 649), a agricultura é "prior" às outras artes. Logo, segundo essa versão, é possível também entender a agricultura também como algo "prévio" ou "anterior" a todos os outros tipos de trabalho. Nesse ponto, Rosenthal está mais próximo do racionalismo aristotélico defendido por Ibn Khaldun, ou seja, há uma construção lógica que vai sempre do mais comum e simples (agricultura) para o menos comum e mais complexo (artes). Já o comércio, segundo a tradução de Al Muqadimma para o inglês, é "a natural way of making profits" (ROSENTHAL, 1967, p. 649), ou seja, é apenas "conforme a natureza" e suas práticas e métodos são "tricky" (ROSENTHAL, 1967, p. 649), palavra que no texto teria um significado mais próximo do termo "complicado" ou "complexo". As duas traduções portanto diferem quando vinculam determinadas práticas ou trabalhos à obtenção do lucro. A tradução para o português coloca o lucro como o resultado de atos de "astúcia" 62 e a tradução para o inglês indica que a prática do comércio é "difícil" e "complicada". Porém, nesse caso, ambas traduções entendem o comércio como algo natural aos seres humanos e às sociedades, mas sempre cronologicamente posterior à agricultura.

O que Ibn Khaldun pretende apontar aqui é a vinculação entre o trabalho e a manutenção e a sofisticação da vida. Seu enfoque é sempre de fundo lógico: sem o mais básico, que para ele é produzido pela agricultura, a sociedade não pode existir e muito menos se tornar mais complexa, ganhando dentro de si novos tipos de trabalhadores, capazes de práticas mais qualificadas. Portanto, a agricultura, na estrutura lógica seguida pelo autor, é o primeiro estágio de uma sociedade quando ela sai da vida nômade e vai para gênese da vida sedentária. Sem a agricultura não é possível atingir uma organização mínima. Economicamente, ela é o ponto de partida (KHALDUN, 1959, p. 325).

Ibn Khaldun aponta também para uma importante distinção entre sociedade nômade e sociedade urbana no que diz respeito às atividades econômicas. A primeira concentra-se no cultivo da terra e na criação de animais, ou seja, é de viés quase agropecuarista. A maior parte dos trabalhos dessas sociedades nômades é feita pelos

\footnotetext{
${ }^{62}$ Nesse ponto, a educação recebida por José Khoury, no seminário Santa Anne, em Jerusalém (ZAIDAN, 2010, p. 123), parece ter levado o tradutor a incorporar ao texto de Ibn Khaldun valores de sua formação católica ao vincular o lucro à astúcia, uma palavra carregada, que vem do latim astutia e significa "trapaça, armadilha, logro". No entanto, não é isso que encontramos no texto quando o mesmo se refere ao lucro e ao comércio. Tal valoração da prática comercial por Ibn Khaldun seria discutível principalmente em razão de o próprio Muhhammad ter sido um comerciante.
} 
grupos familiares e é voltada para satisfazer necessidades básicas como alimentação e vestimenta. Para tal, os trabalhadores utilizam ferramentas simples e fazem muito esforço físico (KHALDUN, 1958, p.203-204). As sociedades do segundo tipo são as cidades, onde as atividades econômicas são mais complexas e com trabalhadores cada vez mais especializados. Apesar de também dependerem de uma base agropecuária mais consistente e ampla, segundo Ibn Khaldun, quando maior for uma cidade, mais gente e mais tempo ela terá para desenvolver ou aperfeiçoar uma determinada técnica. Esse é o caso, segundo ele, dos marceneiros, que constroem mobílias melhores conforme se tornam mais experientes em sua profissão. Nessas cidades a capacidade produtiva é sempre maior (KHALDUN, 1959, p. 238).

De acordo com Ibn Khaldun, quanto mais complexo for o produto, maiores serão a divisão do trabalho e o nível de especialização. Isso, por sua vez, carrega a necessidade de cidades altamente povoadas, dotadas de uma rede de ensino e capazes de gerar processos produtivos cada vez mais coordenados e específicos. Porém, em boa parte tais aperfeiçoamentos "se devem ao luxo e não à necessidade" (KHALDUN, 1959, p.333).

Logo, para ele, o trabalho carrega não só a capacidade de incrementar a teia das relações sociais, mas também é o resultado de uma construção lógica que obedece sempre um roteiro específico, qual seja: em primeiro lugar surgem as sociedades nômades; depois, o estabelecimento de práticas agropecuárias cada vez mais intensivas; e, por último, o surgimento do excedente que permite acúmulo de capital, abundância e tempo livre para atividades voltadas para a aquisição de conhecimento. Em sua concepção da História, Ibn Khaldun buscava uma narrativa com começo (grupos nômades e asabiyya), meio (sociedade do conhecimento) e fim, quando uma sociedade degenera para o comércio de luxo, para a sobretaxação, para governos perdulários e para a falta completa de solidariedade entre seus membros (LIZANA, 2006, p. 232).

Ibn Khaldun, portanto, é mais um autor dentro de uma longa tradição de pensadores que busca classificar os tipos de sociedade, as razões e os mecanismos que as mantêm funcionando. Segundo Fuad Baali (1988, p. 102, tradução nossa),

(...) principalmente entre sociólogos, classificar organizações sociais ou sociedades humanas em dois tipos fundamentais é algo muito em voga. Por exemplo, Spencer as classificou entre militantes e industriais; Maine, em sociedades de status e de contrato; Tönnies, em Gemeinschaft e Gesellschaft; Durkheim, em solidariedade mecânica e solidariedade orgânica; Ogburn, em 
sociedades estacionárias e transformadoras; Sorikin, em sociedades unifuncionais e multifuncionais; Redfield, em sociedades do tipo folk e sociedades urbanas; e Becker, em sociedades sagradas e seculares. Essa tarefa também foi realizada, por exemplo, por Confúcio, Platão, Aristóteles, Agostinho, Tomás de Aquino e Ibn Khaldun.

Dessa forma, a diferenciação entre sociedades urbanas e rurais, presente em $O s$ Prolegômenos, se encaixa em uma tradição sociológica e de análise econômica segundo a qual sociedades mais primitivas possuem vínculos mais fortes, ou seja, são mais estacionárias e voltadas para uma relação mais baseada no status e na solidariedade orgânica. Elas são do tipo folk. Isoladas, homogêneas, iletradas e mais próximas do sagrado (REDFIELD, 1991, p. 293). Já as sociedades urbanas, segundo Ibn Khaldun, estão em constante transformação, são contratuais, distantes da religião e mais propensas ao conhecimento. Nelas, "o cultivo das artes ultrapassa todas barreiras" (KHALDUN, 1959, p. 316). 


\subsection{COMÉRCIO E LUCRO}

No capítulo IX da quinta parte do segundo tomo, a tradução para o português indica que pelo termo comércio entende-se (KHALDUN, 1959, p. 305):

A procura de um benefício ao fazer aumentar o capital por meio de mercadorias compradas a bom preço para serem vendidas mais caro. Que estas mercadorias consistam em escravos, em cereais, em gado, armas ou fazendas é o mesmo. A quantidade do acréscimo conseguida por meio do capital se chama beneficio.

Aqui novamente surge uma diferença com a versão em inglês - na qual a palavra "benefício" é traduzida por "profit". Nesse caso, no entanto, Rosenthal, indica que o termo em árabe é "ribh" - mesmo termo utilizado na primeira vez que o texto cita esse conceito. Tais diferenças indicam uma outra questão: a noção de lucro, palavra que vem do latim $\operatorname{lucru}(m)$, possui no texto de Ibn Khaldun um valor mais próximo do Antiguidade grega e do mundo romano do que daquele presente na civilização cristã. Ele afirma, por exemplo, que é só "por meio do lucro que o homem chega à aquisição" (KHALDUN, 1959, p. 278). O autor também diz que "é necessário o trabalho do homem para tudo que é aquisição e tudo que é fundo de riqueza" (KHALDUN, 1959, p. 278).

Para os romanos, o lucrum era algo legítimo e não portava em si a culpa que por séculos foi um problema dentro de parte do mundo cristão medieval. Nesse sentido, a ideia de comércio presente no mundo árabe é também, em parte, um subproduto do profundo contato que os pensadores muçulmanos, assim como os grandes autores latinos, tiveram com os clássicos gregos. Por exemplo, com o diálogo Hiparco, obra

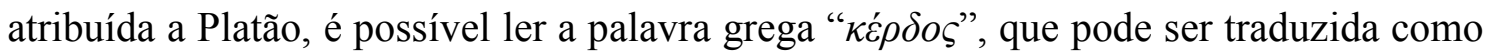
"ganho" ou "lucro". Esse termo grego passou para o latim como "lucrum" e para o árabe como "ribh", “kasb” ou "ku’nia”. Nesse diálogo, é possível ler a pergunta de

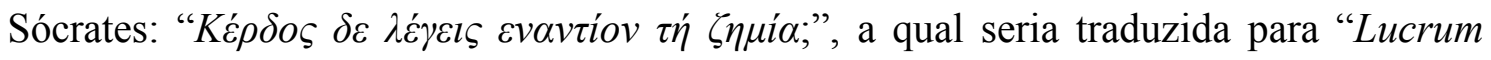
vero dicis damno contrarium? (П $\Lambda \mathrm{AT} \Omega \mathrm{N}, 1784$, V. 5, p. 259) e durante o período de traduções no mundo muçulmano acabaria ganhando sua versão em árabe. Em português sua tradução é: "seria o lucro o prejuízo ao contrário?"63.

\footnotetext{
${ }^{63}$ Aqui novamente temos uma ideia que envolve as relações comercias que é, muita vez, alheia à noção de lucro do pensamento econômico moderno. Em uma sociedade formada primordialmente por pequenos empreendedores, a ideia de "ganho", também presente no termo grego $\kappa \varepsilon ́ \rho \delta o \varsigma$ parece mais próxima da negociação entre, por exemplo, um artesão e um produtor de lã ou couro. Nesse caso, nem sempre a troca
} 
Desse momento em diante, o diálogo questiona o que é o lucro. O texto mostra que os textos gregos na tradição latina da Antiguidade, igualmente aos árabes na séculos depois, davam um sentido mais amplo à palavra lucro ${ }^{64}$. Em razão disso, o diálogo investiga o senso de moral com o qual são guiados os homens que vivem pelo amor ao lucro. Esse mesmo sentimento é analisado no Livro I da República de Platão, quando Sócrates defende que o lucro não é um fim em si mesmo, pois, segundo ele, o médico não trata um paciente apenas pensando no lucro, mas também na busca de um Bem, que é a cura desse indivíduo (PLATÃO, 2001, p. 36).

O mesmo entendimento de lucro e dinheiro está presente na obra $A$ Política de Aristóteles. Nela, o pensador grego afirma que (ARISTÓTELES, 2002, p. 25):

Todas as artes querem indefinitivamente seu fim. A medicina, por exemplo, que tem por objeto a saúde, abarca todos os casos que levam ao seu restabelecimento, que são inúmeros. Mas cada um dos meios de cada arte tem seus limites e está consumado quando chega ao seu fim, isto é, ao último termo que deve avançar.

Esse caminho da palavra serve para indicar que o modelo de pensamento grego se enraizou tanto no ideário latino quanto no pensamento árabe, principalmente depois do movimento de traduções iniciado em Bagdá durante a dinastia Abássida, por volta da segunda metade do século VIII ${ }^{65}$. Segundo Louis Baeck, os pensadores árabes seguem um legado da tradição econômica grega, suas escolas e seus modos e terminologias.

Nesse sentido, não só Ibn Khaldun, mas antes dele Al-Fārābī, Averróis, o kalam e a teologia escolástica grega também discutiram temas como flutuação cambial e relações de troca (PRICE, 1997, p.10).Para Ibn Khaldun, a busca pelo lucro deve ocorrer e faz parte da vida em sociedade, porém, assim como pensavam os gregos, não deve ser um fim em si mesma. O campo no qual ela se dá é o do comércio: "a arte de fazer crescer o capital" (KHALDUN, 1959, p. 305).

O texto de Os Prolegômenos, portanto, carrega em si algo grego, que serve como plano a ser superado. É uma obra que indica o quanto o "pensamento humano é

comercial era representada por valores em dinheiro, mas poderia ser feita de maneira que ambas partes obtivessem algum ganho. Muita vez, esse parece ser o quadro analisado por Ibn Khaldun, principalmente quando trata das sociedades menos desenvolvidas. Há no texto de Ibn Khaldun duas ideias: ganho e lucro que são complementares e representam, de certa forma, estágios diferentes de uma sociedade.

${ }^{64}$ Aqui, portanto, o texto de Ibn Khaldun segue uma tradição possivelmente vinculada ao pensamento grego.

${ }^{65} \mathrm{O}$ movimento de tradução em si se refere a cerca de 200 anos de trabalhos de trabalho ocorridos em Bagdá que vão da segunda metade do século VIII até a primeira metade do X. Nesse período, textos não literários e não históricos, escritos em grego, foram traduzidos para o árabe. 
um diálogo ininterrupto entre o passado e presente, entre o presente e o futuro"66 (ALJABRI, 1999, p. 155). Por exemplo, em A Política, Aristóteles afirma que uma das maneiras para enriquecer é pelo comércio, "profissão voltada inteiramente para o dinheiro, que sonha com ele, que não tem outro elemento nem outro fim, que não tem limite onde possa deter-se a cupidez" (ARISTÓTELES, 2002, p. 25). Ibn Khaldun, por sua vez, entende o comércio não só como algo positivo, mas também algo natural às sociedades (KHALDUN, 1959, p. 304-306). Nesse sentido, é possível afirmar que o texto de Ibn Khaldun carrega em si um olhar a respeito do trabalho, do comércio e do lucro que, de certa forma, representa uma superação à sua fonte aristotélica. Na sociedade em que Ibn Khaldun vivia, "parte da produção era direcionada ao mercado" (RODINSON, 1974, p. 33), ou seja, ocorria em uma chave menos moralista.

Além de sua vinculação com ideias gregas e latinas, essa relação mais pragmática com tais práticas está ligada também à "nova moral” surgida da religião muçulmana, a qual em seu nascedouro buscou garantir a produção de determinados produtos em Meca, cidade onde surgiram ofícios como "carpintaria, ferraria, feitura de espadas, comércio de vinhos, azeite, couros, alfaiataria, tecelagem, fabrico de flechas, papelaria, (...) agiotagem" (MARGOLIOUTH, 2012, p. 26). Devemos lembrar também que o próprio Muhhammad tinha profundo vínculo com esse ambiente comercial em razão de ter sido ele chefe de caravana, transportando e vendendo determinados produtos.

Assim, o autor de Os Prolegômenos entende que o comércio é a "arte de fazer crescer seu capital comprando mercadorias e procurando vendê-las mais caro do que custaram" (KHALDUN, 1959, p. 305). Ele também enumera quais são as maneiras para conseguir maiores lucros. Elas são: armazenar as mercadorias e esperar pela subida dos preços; importá-las para outro país onde há maior demanda; ou vendê-las a prazo ou no mercado futuro, no qual é possível, "receber seu preço em épocas ulteriores" (KHALDUN, 1959, p. 305). É importante ressaltar aqui que Ibn Khaldun, quando faz

\footnotetext{
${ }^{66}$ Conta a lenda que Sargão, o acádio, teria sido o líder máximo do primeiro grande império da Mesopotâmia, que existiu dois mil anos antes da era cristã. A lenda de Sargão narra que, ao nascer, ele teria sido colocado em uma cesta de vime e lançado ao rio por sua mãe sacerdotisa. Horas depois, Sargão foi encontrado por um homem chamado Akki, o qual trabalhava como jardineiro para Ur-Zababa, o rei da cidade suméria de Kish. Quanto atingiu a idade adulta, o pequeno bebê dessa narrativa se tornaria o grande comandante de seu povo. Essa história, praticamente idêntica à de Moisés, mostra a enorme versatilidade das ideias. Em muitos casos, em razão de sua maleabilidade, elas simplesmente ganham novos formatos em outros contextos. Da mesma forma, isso ocorre com o dualismo presente em religiões anteriores à tradição cristã como o zoroastrismo e com muitas das ideias presentes em Os Prolegômenos.
} 
julgamento moral da prática comercial, é para compreender tal fenômeno mais pragmaticamente. Para o autor de Os Prolegômenos, o comércio era um dado da realidade econômica motivado por relações que são intrínsecas aos seres humanos, os quais são, por natureza, citadinos (KHALDUN, 1958, p. 105). Segundo ele, porque "todos os homens cobiçam bens alheios" (KHALDUN, 1959, p. 306), o comércio tornase um fato da realidade. Sua análise é uma tentativa de revelar o funcionamento desse fato. Nesse esforço, Ibn Khaldun mistura a tradição grega e latina, a moral muçulmana e um olhar pragmático na busca pelos mecanismos que estão por trás do funcionamento econômico do comércio e do lucro. 


\subsection{PODER CENTRAL}

Outro importante fator para a manutenção da vida em sociedade e da cultura (Umrān), além da valoração do trabalho, é o da existência de um "governo capaz de manter a ordem" (KHALDUN, 1959, p. 133).

Nesse ponto, Ibn Khaldun (1959, p. 134) fala da Cidade perfeita (Al-Madīnat alfādilah), em uma clara alusão ao Livro das opiniões dos habitantes da cidade ideal de Al-Fārābī (878-950), o qual, por sua vez, retirou esse conceito dos textos de filósofos neoplatônicos da Antiguidade tardia e possivelmente também de Aristóteles (PINES, 1986, p. 146-156)

Tanto Al-Fārābī quanto Ibn Khaldun, acreditam que a Cidade perfeita é aquela com uma hierarquia bem estabelecida e na qual todos atuam voluntariamente e "em conformidade com a direção do chefe" (ATTIE FILHO, 2002, p. 219). Por exemplo, é possível ler, no primeiro tomo dos Prolegômenos, a seguinte passagem (KHALDUN, 1958, p. 336):

Cada homem levanta a mão para a coisa que cobiça e procura arrancá-la ao vizinho, tanto a violência e a inimizade são paixões inerentes à natureza de todos animais. A vítima, tomada de indignação e cólera, resiste com todas as suas forças à tentativa do agressor. A contestação gera um conflito, que se transforma em combate generalizado, provocando efusão de sangue e morte de muitos indivíduos, o que redundaria no aniquilamento da espécie humana.

Para Ibn Khaldun, a solução para tal problema é a existência de um poder central. Por ter vivido em um momento de grande agitação política, Ibn Khaldun defende a obediência à autoridade a partir de uma análise da natureza humana e de como as sociedades se constituem. Ibn Khaldun afirma que os homens "não podem viver sem um chefe que os impeça de se atacarem uns aos outros" (KHALDUN, 1958, p. 336) - algo muito semelhante ao "homo homini lupus" de Plauto (254-184).

A época de Ibn Khaldun é um período de reforma religiosa que distancia o autor do mundo islâmico da falsafa e o aproxima de líderes como Tamerlão (1336-1405), figura praticamente oposta ao rei filósofo da Cidade virtuosa (Al-Madina al-fadila) de Al-Fārābī (BAECK, 1996, p. 88-89). Enquanto o sábio-profeta de Al-Fārābī seria alguém que teria atingido "o grau supremo da felicidade humana que consiste em se unir à inteligência agente, sendo, assim tocado pela revelação profética e por toda inspiração" (ATTIE FILHO, 2002, p. 200-201), Tarmelão era um mestre da política, um 
exímio estrategista militar e um líder "capaz de conquistar e manter a lealdade dos seus seguidores nômades e assim atuar e transformar uma estrutura política extremamente fluida" (MANZ, 1999, p. 16, tradução nossa). Acrecenta-se a isso a figura do mahdī tumartiano. Segundo Niane (2010, p. 26),

Há um elemento da doutrina tumartiana que se desviava nitidamente das posições sunitas: é a crença num mahd̄̄ (o guia impecável), que é guiado por Deus. As tradições relativas ao mahdī remontam ao Profeta, a quem se atribuem hadith que anunciam a vinda de um restaurador, de um redentor, pertencente à família do Profeta. Para os sunitas, o mahdī só deverá aparecer à véspera do fim dos tempos, para restabelecer e aplicar a verdadeira religião. Para os xiitas, é um imã oculto que deve reaparecer e governar pessoalmente por direito divino. Entre as classes populares, a crença no mahdī era bastante difundida por simbolizar a justiça; essa esperança é ainda atestada no século XIV por Ibn Khaldūn.

O autor de Os Prolegômenos também afirma que "nenhum indivíduo pode apossar-se do que outrem obteve, a menos que dê a este alguma coisa em troca" (KHALDUN, 1958, p. 227). Assim, a troca ou aquisição, além de necessárias, só são viáveis quando os produtos trocados ou adquiridos são valorados de forma justa, o que só é possível quando há um poder instituído capaz de ancorar qualquer negociação, seja ela de troca ou de compra.

Segundo Ibn Khaldun, "atentar contra os homens, apossando-se de seu dinheiro, é tirar-lhes a vontade de trabalhar para possuir mais; porque veem que afinal de contas acaba-se por tirar-lhes tudo. Perdendo a esperança do lucro, deixam o trabalho" (KHALDUN, 1959, p. 101). Aqui, Ibn Khaldun defende que para ser justa uma sociedade necessariamente deve possuir regras de conduta que estabelecem direitos e deveres. Portanto, nesse sentido, o trabalho e o lucro que cada membro dessa sociedade produz só vão ocorrer quando existir uma justa ordem social ${ }^{67}$.

Paradoxalmente, Ibn Khaldun - para quem a escravidão dos povos negros não era um problema (KHALDUN, 1958, p. 260) - qualifica como as mais graves formas de opressão aquelas que forçam o povo a trabalhar sem retribuição ou quando "um governo constrange os negociantes a cederem-lhe por um preço baixo as mercadorias que

\footnotetext{
${ }^{67}$ Em 1893, Émile Durkheim (1858-1917) publicaria uma tese de doutoramento intitulada De la Division du Travail Social com ideias muito semelhantes às de Ibn Khaldun. Tanto a solidariedade mecânica quanto a orgânica de Durkheim estão, de certa forma, presentes nas ideias do pensador árabe. Essa semelhança já foi citada pelo filósofo Ernest Gellner (1925-1995). Segundo Gellner, Ibn Khaldun e Durkheim são teóricos da coesão social que têm como questão principal descobrir o que mantém uma sociedade unida (Muslim Society, páginas 86-87). Novamente temos aqui mais um indicativo de que história do pensamento econômico é mais ampla e deve necessariamente incluir textos árabes em seu escopo. O trabalho de Ibn Khaldun em economia "transcendeu grandemente aquele presente nas obras" dos gregos (SPENGLER, 1964, p. 304) em razão de estar profundamente vinculados aos mesmos.
} 
possuem, obrigando-os depois a comprarem dele outras por preços excessivos" (KHALDUN, 1959, p. 106). Segundo ele, um governo não deve jamais "comprar ou vender por via da violência e do constrangimento" (KHALDUN, 1959, p. 106) e o trabalho deve sempre estar entre a "categoria das ocupações lucrativas" (KHALDUN, 1959, p. 105).

Portanto, para Ibn Khaldun, uma sociedade justa não é apenas aquela que é virtuosa, mas também a que for capaz de organizar sua mão de obra de maneira que seja possível que os indivíduos lucrem com suas ocupações, tenham segurança para fazer negócios e fiquem protegidos de violentas interferências do governo. Isso ocorre somente em um ambiente com regras estabelecidas e mantidas por um poder central forte profundamente tomado pelo sentimento de asabiyyah e respeito às leis corânicas, segundo o autor de Os Prolegômenos. Assim, surge uma teoria valor-trabalho amparada por uma teoria política que antecipa quais os problemas um Estado pode sofrer caso não adote as melhores práticas na administração pública e na taxação de seus súditos.

Aqui Ibn Khaldun mostra-se, ao mesmo tempo, defensor de um Estado regulador e de forte presença, mas modesto na cobrança de impostos. O autor, portanto, defende uma economia mais livre e autorregulada, a qual, contraditoriamente, deverá ser mantida por um Estado forte e atuante.

Ibn Khaldun é, portanto, duro crítico do Estado que cresce demais e aumenta excessivamente as despesas de custeio da máquina pública, tornando-se, segundo ele, altamente burocratizado e ineficiente. Em Os Prolegômenos, o autor combate políticas fiscais baseadas no constante crescimento na arrecadação de impostos ${ }^{68}$. Porém, ele defende, ao mesmo tempo, um poder central forte e portanto caro em razão da inevitável despesa com forças de segurança. Ibn Khaldun acredita que somente um poder forte é capaz de manter as relações comerciais e a segurança jurídica de uma sociedade (KHALDUN, 1959, p. 115). Na sua visão, uma dinastia atinge seu auge quando consegue combinar as duas coisas. Contudo, seu texto busca solucionar essa contradição ao instituir que toda e qualquer dinastia não conseguirá manter esse equilíbrio por muito tempo e inexoravelmente acabará entrando em decadência.

\footnotetext{
${ }^{68}$ Esse liberalismo avant la lettre, que combate possíveis entraves à lei de oferta e demanda, critica o Estado que sobretaxa a população ou interfere negativamente no comércio e vê nos ciclos demográficos e no crescimento populacional o caminho para a especialização dos trabalhadores e o aumento da produtividade transforma o texto de Ibn Khaldun em uma referência na história do pensamento econômico.
} 
Essa análise econômica, que entende a formação dos preços de maneira racional e empírica, baseando-se para isso no comportamento dos consumidores e do poder - se ambos estão próximos ou distantes da asabiyyah -, desempenha um papel fundamental na teoria de Ibn Khaldun para explicar o declínio dos impérios. Quanto melhor funcionar a economia de uma determinada civilização, mais chances ela terá de frutificar e crescer, porém, invariavelmente, ela sucumbirá tomada pelo luxo e pelos altos impostos (KHALDUN, 1959, p.121).

Ibn Khaldun acredita que um governo moralmente correto, ou seja, comandado pelo sentimento de asabiyyah, não cobra muitos impostos, isso, por sua vez, ajuda a ampliar a produção e facilitar a vida, pois mantém os preços sob controle (KHALDUN, 1959, p.119). Já um governo moralmente fraco e injusto, isto é, distante da asabiyyah, acaba aumentando impostos para manter suas regalias palacianas. Nesse sentido, o nível de taxação é, para Ibn Khaldun, o termômetro que vai indicar se um governante é moralmente corrompido ou não (KHALDUN, 1959, p.119-122).

Contudo, na análise de fundo pessimista feita pelo autor, a organização social das sociedades, muçulmanas ou não, inexoravelmente se repete ao caminhar para a sobretaxação dos seus membros, o comércio de luxo e posterior esgotamento. Ibn Khaldun (1958, p. 89) afirma:

Como os impérios que nascem sentem-se imbuídos das influências de sua vida nômada (que até então os moldou), os seus chefes ignoram o luxo e seus hábitos, e suas necessidades são poucas. Suas despesas são mínimas, a renda arrecadada chega para tudo cobrir, e pode mesmo sobrar bastante. Todavia, não tardam a adotar usos da vida sedentária e os hábitos de luxo, seguindo, neste caminho, o exemplo das dinastias que os precederam. Isto produz um grande aumento nos gastos do Estado e sobretudo nos dos sultão, porque é obrigado a prover às despesas de todas as pessoas de sua casa e de presentear muitos. Como a renda do império torna-se insuficiente para o pagamento do soldo às tropas e das despesas do soberano, o governo se acha forçado a remediar a esta penúria pelo aumento da taxa dos impostos.

Para Ibn Khaldun, esse caminho de sobretaxação pode demorar mas não irá nunca falhar. Conforme a vida dos poderosos torna-se cada vez mais dispendiosa, eles são levados a aumentar os impostos, tornam-se reféns do "amor à ostentação" e da "prodigalidade desenfreada" (KHALDUN, 1959, p. 122). Desfechando assim um golpe no "império pelo lado das finanças" (KHALDUN, 1959, p. 122).

A conclusão desse movimento de sobretaxação é a seguinte (KHALDUN, 1958, p. 88-89): 


\begin{abstract}
Mais tarde o imposto excede os limites da moderação e aniquila, no lavrador, o amor ao trabalho. Comparando despesas e encargos com que deve arcar, se deixa levar ao desânimo e muitos agricultores renunciam a cultivar a terra, o que provoca uma queda no produto do imposto e, como consequência necessária, na renda do Estado. Algumas vezes, quando os chefes do império se apercebem desta diminuição, imaginam poder remediar o déficit pelo aumento dos impostos, e continuam seguindo este sistema até que a taxa das contribuição chega a um limite além do qual nenhum proveito resta para o cultivador. Os gastos da lavoura e os impostos absorvem tudo e não deixam nenhum lucro esperado. Como a renda não deixa de diminuir, o governo continua a aumentar taxas e contribuições na esperança de tapar o déficit; renuncia-se ao cultivo da terra, porque se perdeu a esperança de tirar proveito de seu trabalho; o que redunda em prejuízo para o Estado. Com efeito, quando a agricultura é de muito rendimento, é o governo quem aproveita de sua prosperidade.
\end{abstract}

Cobrar impostos além do necessário é, segundo Ibn Khaldun, característica de um governo já acostumado às riquezas e à vida palaciana. Para ele, quanto mais dura a política fiscal de um governo for, mais longe esse poder está da fortitude moral e do sentimento de grupo (asabiyyah) dos tempos que remetem a um quase estado de natureza no qual vivem os nômades (KHALDUN, 1959, p. 119). Para Ibn Khaldum, isso é o mesmo que renunciar aos mandamentos da religião (KHALDUN, 1958, p. 221).

Nesse ponto, Ibn Khaldun parece defender o mesmo que Aristóteles quando este fala do uso da moderação em sua obra $A$ Política. Para ser um líder justo, segundo Aristóteles (2002, p. 249-250), o governante deve

Em primeiro lugar (...) se preocupar com o bem público; que evite as despesas que ferem o povo, como a dilapidação das finanças, que se abstenha de fazer, às custas dos pobres que têm tanta dificuldade para economizar, grandes gastos, principalmente essas generosidades escandalosas, como pensões para suas amantes e para os encarregados de seus prazeres, para estrangeiros sem mérito, para artesãos de corrupção e de imoralidade; que preste contas da percepção e do emprego dos impostos (...) Que demonstre principalmente muito zelo pela religião. Teme-se menos injustiça da parte de um príncipe que se crê seja religioso e parece temer aos deuses, e se está menos tentado a conspirar contra ele quando se presume que tem assistência e o favor do Céu. Mas é preciso que sua piedade não seja afetada, nem supersticiosa.

Apesar de estar na mesma chave moral que Aristóteles, Ibn Khaldun acredita ser impossível perpetuar o bom governo. Em algum momento, os poderosos se acostumam às benesses do poder e sobretaxam a população para financiar a opulência (KHALDUN, 1959, p. 115).

Logo, toda dinastia, ao se tornar um império, acaba cedo ou tarde aumentando demais seus custos com serviços públicos (manutenção de portos, estradas, controle da irrigação e do uso da água, por exemplo), gasta mais para manter suas forças de segurança, sem as quais não é possível garantir sua autoridade, e também acaba 
investimento no mecenato ligado à educação, às artes e ao conhecimento científico. Dessa maneira, quanto maiores são os gastos, maiores ficam os impostos. É esse círculo vicioso, somado à inevitável tendência de todo governo ser tomado pelo "luxo e o fausto" (KHALDUN, 1959, p. 115) que, segundo Ibn Khaldun, leva toda dinastia à falência.

De certa forma, Ibn Khaldun também acredita que "impostos são aquilo que pagamos para ter uma sociedade civilizada" - como afirmou o ministro da Suprema Corte dos EUA Oliver Windell Homes (AARON; SLEMROD, 2004, p. 362, tradução nossa). A diferença reside no pessimismo que entende como impossível que o governo mantenha uma taxação justa de maneira ininterrupta, ela sempre vai caminhar para a sobretaxação. Assim, Ibn Khaldun encara o surgimento, auge, decadência de uma sociedade a partir de uma ótima moral e religiosa que entende como "natural" esse ciclo, ou seja, ele é o resultado inevitável da natureza efêmera e falível dos seres humanos e das sociedades.

Dessa forma, em Os Prolegômenos a tributação significa a existência de uma representação política. Para ele, sem tributos não há comando e sem comando não há sociedade. Logo, os impostos fazem parte do processo civilizatório descrito no texto kahlduniano. No entanto, toda e qualquer forma de governo, para Ibn Khaldun, acabará taxando excessivamente seus membros e essa sociedade, depois de um momento de progresso, acabará entrando em decadência. 


\subsection{O PERENE E O EFÊMERO}

Ibn Khaldun, como vimos, viveu em um momento no qual o poder árabe entrava em um ciclo de contração e caminhava em direção a uma posição mais distante dos centros de poder da geopolítica mundial. O autor de Os Prolegômenos presenciou conquistas, derrocadas e já tinha notícias sobre o desenvolvimento do conhecimento em outras regiões. Segundo ele (KHALDUN, 1960, p. 130-131),

(...) no País dos Francos, região formada pelo território de Roma e das comarcas que dela dependem, isto é, as que formam a margem setentrional do Mediterrâneo, a cultura das ciências é muito próspera. Dizem que as ciências ao floresceram, que os cursos instituídos para o ensino destas ciências são muito numerosos, os compêndios que delas tratam são muito completos, e são muitos os homens que conhecem-nas a fundo e que são numerosos os estudantes empenhados em estudá-las.

Tentando captar o espírito de seu tempo e a fragilidade e a crise de sua sociedade, Ibn Khaldun se mostra um pensador profundamente atento ao que ocorria no mundo que o formou. Tal contexto ajudou a tornar sua obra um importante mecanismo para compreender as transformações sociais daquela época.

Ele fundamenta sua cosmovisão a partir das informações econômicas e sociais que encontra na realidade. Seu trabalho inova em razão de utilizar a lógica aristotélica, ou seja, com o mesmo mecanismo mental usado pelos filósofos na metafísica ele analisa a história. Sua cuidadosa investigação da mão de obra, da divisão e valoração do trabalho, do papel da oferta e da demanda na economia e no progresso de uma civilização, da força do comércio como fonte não apenas de apenas de lucro, mas de contatos com outras culturas e meio para perpetuar técnicas e conhecimentos é profundamente alicerçada no real e, em razão disso, inovadora.

Ibn Khaldun apresenta em Os Prolegômenos o resultado racional dos fatos históricos e econômicos por ele analisados. Através da lógica, essa investigação chega a um formato que, para o autor, perpassa todas as sociedades. Ibn Khaldun encontra uma "forma", um "carimbo" presente em todas as grandes civilizações que ele chama de $o s$ primeiros inteligíveis (KHALDUN, 1960, p. 226).

Essa espécie de "superestrutura" que resulta das investigações feitas por Ibn Khaldun é o resultado lógico de sua pesquisa. Ela propõe um determinismo histórico, que, de acordo com a análise, só seria possível retardar, mas jamais evitar. Para Ibn 
Khaldun, toda sociedade, seja ela muçulmana ou não, caminha para seu fim conforme se civiliza e sofistica sua economia. Inevitavelmente, conforme o autor de Os Prolegômenos acredita, essa sociedade será substituída ou dominada por outro grupo saído do nomadismo e da vida próxima à natureza. Assim, suas análises de fundo pessimista confluem para a ideia de que tudo caminha inexoravelmente para a decadência em direta razão de seu progresso econômico.

Como tudo na crise ganha a força do óbvio, seus textos apontam o que há de disfuncional e funcional nos governos de seu tempo. A história para Ibn Khaldun é uma espiral que ascende quando seus líderes são guiados pela asabiyyah (ou pela moderação no casos de civilizações não islâmicas) e declina quando o luxo e a futilidade se tornam a regra.

Ao partir de um contexto de profunda transformação ${ }^{69}$, Ibn Khaldun apresenta uma estrutura que, segundo ele, está presente desde a formação até a derrocada dos grandes impérios. É dentro dessa nova maneira de fazer história que ele percebe a importância de uma teoria subjetiva do valor, da expansão da riqueza vinculada ao aumento populacional, dos ciclos sociais (LALLEMENT, 2003, p. 31) e da utilização do texto sagrado como guia para o bom governo.

Ibn Khaldun acreditava que o reino da pura razão não era algo universal ou um imperativo categórico. Tal reino possuía suas limitações naturais. Para ele, os seres humanos não são movidos apenas pela busca do conhecimento e do Bem. Eles também são atraídos pelo poder e por aspirações materiais como riqueza (KHALDUN, 1959, p. 306). Segundo ele, quando o desejo pelo conforto degenera em luxúria seu resultado é a destruição social (BAECK, 1996, p. 88). Em razão disso, a obra de Ibn Khaldun, segundo André Miquel, possui um inegável caráter introspectivo e pessimista (MIQUEL, 2001, p. X) que deve, em muito, à crise política, econômica e demográfica produzida pela Reconquista, o esfarelamento do islã em vários reinos no norte da África e da chegada da peste negra no mundo muçulmano. Seu texto retrata, amplia e desvenda (e busca responder) as dificuldades do tempo em que foi produzido. Defende, em razão

\footnotetext{
${ }^{69}$ Aqui acredito que cabe apontar que outras relevantes análises também partiram de contextos de crise, ressentimento e transições econômicas, políticas e sociais. Karl Marx, por exemplo, vislumbrou pessoalmente, na Inglaterra vitoriana, a força do capitalismo que, ao mesmo tempo, elevava a produtividade, gerava uma acumulação capitalista moralmente obscena e aumentava a miséria humana nos bairros proletários; John Maynard Keynes, por sua vez, pode ver o enorme erro que seria produzido no futuro pela Conferência de Versalhes, em 1919, a qual acabaria jogando a humanidade na Segunda Guerra Mundial.
} 
disso, um governo forte e uma sociedade contratual e empreendedora, onde as vendas devem ser feitas "por meio de documento escrito ou declaração de testemunhas" (KHALDUN, 1959, p. 305) e na qual o trabalho é corretamente valorado ${ }^{70}$.

Assim, a leitura de Os Prolegômenos remete a imagem da realidade que funciona como uma escada em espiral. Seus ciclos podem significar progresso ou declínio. Ibn Khaldun aponta os componentes de geração e auto deterioração presentes em qualquer grupo e como essa espiral pode funcionar negativa ou positivamente, respectivamente, trazendo decadência ou desenvolvimento. O movimento dessa espiral da história é determinado pela proximidade da sociedade daquilo que é mundano e do que é divino. Segundo ele, quando estamos mais próximos do primeiro, descemos alguns degraus; quando seguimos as regras do segundo, subimos.

Os ciclos nos quais surgem e desaparecem os impérios nessa escada em espiral representam um poder que foi carcomido pela própria opulência, mas que deixou para o próximo grupo dotado de asabiyya um grau maior de conhecimento, que, para ele, é o hábito enraizado pela repetição (KHALDUN, 1959, p. 316). Dessa forma, o conhecimento, ou parte dele, forma uma extensa rede que passa de uma sociedade para outra. Ibn Khaldun o descreve como um fluxo, muita vez intermitente, que se autopreserva e se auto-organiza em razão diretamente proporcional ao tempo de manutenção de uma determinada civilização. Quanto maior for a história dessa civilização, maior também será a chance de ela manter determinadas redes comerciais, de fixar determinadas técnicas e conhecimentos e de passá-los para frente.

Segundo o autor de Os Prolegômenos (KHALDUN, 1959, p. 318),

Túnis se parece com as cidade andaluzas (...) a civilização tomou nela grande incremento sob a dinastia dos Sanhaja (Ziridas) e depois sob a dos Almohadas (Hafsidas), e as artes de todo gênero alcançaram ali alto grau de perfeição. Esta cidade tinha ficado entretanto, sob este ponto, num estado de

\footnotetext{
${ }^{70}$ Tanto Ibn Khaldun quanto pensadores europeus considerados clássicos da economia entendem que a riqueza de uma sociedade resulta diretamente do trabalho de seus indivíduos e que o valor de troca de tudo o que nela é produzido representa a soma do tempo gasto e das habilidades necessárias para a sua produção. Há aqui, portanto, ideias que seriam correntes alguns séculos depois na Europa. São elas: consenso sociocultural, o qual é fruto de um espírito de grupo (asabiyyah) e deve ter como objetivo a satisfação das necessidades básicas da população; um poder capaz de fazer valer os acordos comerciais e manter a estabilidade jurídica; baixa taxação; e um ambiente voltado para o empreendedorismo, o lucro, as trocas comerciais e a difusão do conhecimento através do ensinamento das artes (qualificação da mão de obra). Para ele, esses são fatores decisivos de sucesso. Há, portanto, uma inegável semelhança entre os conceitos econômicos fundamentais presentes na obra de Ibn Khaldun e em trabalhos como Ensaio sobre a Natureza e as Causas da Riqueza das Nações, de Adam Smith; Princípios de Economia Política e de Tributação, de David Ricardo; Ensaio sobre o Principio da População, de Thomaz Malthus; e Princípios de Economia Política, de John Stuart Mill.
} 
inferioridade, quando comparada com as cidades andaluzas, mas a proximidade do Egito e o grande número de viajantes que transitaram entre este país e a Mauritânia, tiveram por resultado a introdução de um número das artes já existentes na cidade. Tunisianos moram às vezes no Cairo durante anos, e na sua volta trazem os hábitos de luxo egípcio e o conhecimento da artes do Oriente, conhecimento que lhes granjeia muita e alta consideração. Daí resulta que, sob o ponto de vista das artes, Túnis se parece com o Cairo. Parece-se também com as cidades andaluzas, por descender a maior parte de seus habitantes de nativos de al-Andaluz oriental que tinha vindo nela se refugiar quando da grande emigração do século XII. Por isso, as artes se mantiveram em Túnis, embora esta cidade não esteja num estado de prosperidade que possa justificar sua existência. Mas uma vez que a tintura ficou firme num tecido, não desaparece, a menos que desapareça o tecido.

A transmissão desses conhecimentos ocorre de maneira inconstante, não planejada e resulta de uma série de combinações de elementos comerciais, políticos e geográficos. Ela é tão efêmera quanto a presença humana. Nesse sentido, para Ibn Khaldun, a intrínseca capacidade de autodestruição presente nas sociedades se opõe à lei divina, que é perfeita e indestrutível (KHALDUN, 1967, p. 583). As teorias econômicas e o pensamento de Ibn Khaldun têm, portanto, um fundo teológico, apesar de utilizar amplamente as ferramentas oferecidas pela razão como a lógica aristotélica. Nelas, a correta valoração do trabalho somada à não intromissão do governo na produção agrícola, de manufaturados e no comércio aproxima a sociedade e o poder da asabiyyah, isto é, da correção regiliosa.

Nesse sentido, é possível aproximar a teoria do conhecimento e principalmente a teoria econômica de fundo moral de Ibn Khaldun com os versículos 43 e 44 da $35^{\text {a }}$ surata (Fáter) do Alcorão, onde se lê:

Em ensoberbecimento na terra e em conspiração para o mal; todavia, a conspiração para o mal somente assedia os seus feitores. Porventura, almejam algo, além da sorte dos povos primitivos? Porém, nunca acharás variações na Lei de Deus; e nunca acharás mudanças na Lei de Deus ${ }^{71}$.

Porventura, não percorreram a terra, para ver qual foi o destino dos seus antecessores, que eram mais poderosos do que eles? Porém, nada poderá desafiar Deus, nos céus ou na terra, porque é Onipotente, Sapientíssimo ${ }^{72}$.

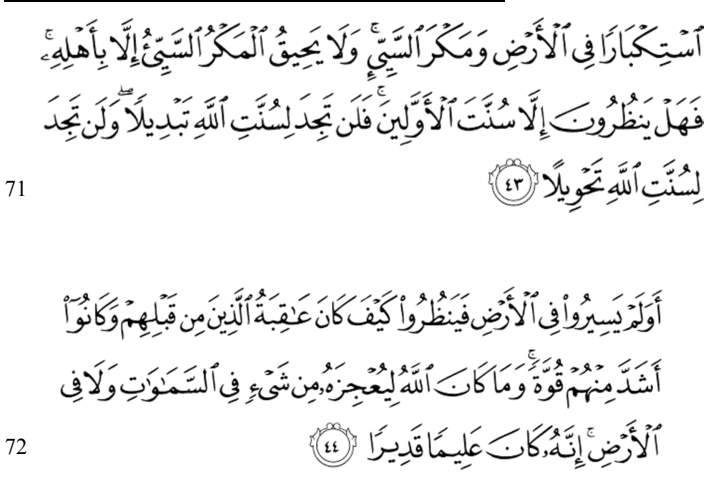


Em tais versículos corânicos é possível ler que as mudanças e o mal presentes no mundo não estão presentes no âmbito do divino, onde tudo é perfeito e imutável. Ibn Khaldun acreditava que Deus criou esse padrão para a vida em sociedade. Não importa onde ela ocorra, sempre terá começo, auge e declínio em razão de sua inseparável e inescapável vinculação com a realidade. Paradoxalmente, ele utiliza ferramentas conceituais alheias à religião (KHALDUN, 1960, p. 225-236) para explicar como esse ciclo ocorre, ao indicar que os povos tribais e nômades são a maior e mais importante força de renovação da população citadina. Os nômades e beduínos, segundo ele, são aqueles que vão trazer nova vida e fortitude moral para as populações que habitam grandes cidades. Para Ibn Khaldun, o funcionamento do mundo criado por Deus é um sistema que beneficia o caráter moral de um grupo. Em razão disso, as tribos do deserto conquistam o poder em razão dessa fortitude moral, a qual, por sua vez, é produto de sua vida simples e da forte presença do espírito de solidariedade "asabiyyah" 73.

Em Os Prolegômenos podemos ver que essa mesma disputa entre o divino e mundano ocorre em cada ser humano (KHALDUN, 1960, p. 232).

O homem é composto de duas partes, uma das quais, a parte espiritual, é associada à outra, que é a parte corporal. Cada uma dessas partes dispõe de percepções que lhes são peculiares, mas há somente uma parte, a espiritual, que recolhe estas duas classes de percepções. Recebe, às vezes, percepções espirituais e outras vezes corporais.

Cada um de nós, segundo Os Prolegômenos, carrega em si essa mesma contradição e esse mesmo embate. Logo, as sociedades não poderiam ser diferentes. Dentro delas há, ao mesmo tempo, a asabiyyah e o caminho da moderação (que nas sociedades no norte da África são idênticas à retidão muçulmana) e a tendência ao luxo e ao sedentarismo.

Além disso, Ibn Khaldun também diferencia dois tipos de sistemas políticos. Um fundamentado em Deus; outro, na razão. No primeiro caso, o sistema oferece vantagens

\footnotetext{
${ }^{73}$ Nesse ponto é, a meu ver, praticamente impossível resistir às semelhanças existentes entre $O s$ Prolegômenos e Os Sertões. Separadas por séculos, ambas obras são divisores de água na história das ciências sociais de suas respectivas culturas. Ibn Khaldun e Euclides da Cunha, cada um à sua maneira e a seu tempo, pretendem produzir uma "descrição sociográfica e de interpretação histórico-geográfica do meio físico, dos tipos humanos e das condições de existência" (Fernandes, 1977, p. 35). Tanto para o mundo árabe quanto para Brasil, em razão da semelhança dos propósitos das duas obras, a frase entre aspas, escrita por Florestan Fernandes sobre o livro de Euclides da Cunha, cabe perfeitamente na descrição do texto de Ibn Khaldun. Porém, chama mais nossa atenção o fato de que para ambos, esses povos - sertanejos e beduínos - são uma espécie de reservatório moral, um antídoto à vida de confortos e riquezas das grandes cidades.
} 
à população neste mundo e no outro (KHALDUN, 1960, p. 133). As cidades do segundo caso, por sua vez, oferecem apenas vantagens para a vida de agora. Porém, em ambas situações, o final é o mesmo: o declínio.

A cidade onde a razão domina funciona sobre uma lei de interesse geral (KHALDUN, 1960, p. 134), mas que é fruto de seu tempo e, portanto, passível de mudança e corrupção. Já no caso da cidade que segue a lei divina, há um alicerce jurídico (o Alcorão), que não muda porque, para Ibn Khaldun, é perfeito, irretocável. Porém, o autor acredita que nem mesmo uma lei perfeita impede a mudança das pessoas e dos governos, que invariavelmente se corrompem.

Há, em Os Prolegômenos, esse constante atrito entre o mundano e o divino. Essa dimensão social da vida, seja ela de fundo teológico ou baseada na razão, está fadada ao ciclo de desenvolvimento que, na visão do autor, torna-se invariavelmente insustentável.

Dentro desse constante embate, ele reconhece presente nas civilizações uma maneira de funcionar que é comum a todas as grandes cidades. Esse mecanismo presente no comportamento dos grupos sociais descrito em Os Prolegômenos em muito se parece com um tema crucial do trabalho filosófico que ele descreve e critica: os primeiros inteligíveis (KHALDUN, 1960, p. 226).

Consiste a sua doutrina no seguinte: a especulação, por meio da qual se chega a distinguir o verdadeiro do falso, se exerce pelo entendimento, enquanto que ele opera sobre ideias derivadas de seres individuais. Por meio da abstração, o entendimento retira destes indivíduos [os filósofos] certas formas que se adaptam a todos eles, assim como um carimbo se adapta a todas as impressões que teria deixado na argila e na cera. Estas formas abstratas chamam-se: os primeiros inteligíveis. Tomam-se, depois, estes inteligíveis ou ideias universais e se examina se possuem algo em comum com outas ideias (gerais), das quais diferem, mas a ponto do entendimento poder perceber esta diferença. Abstraem-se, destas duas classes, as ideias que lhe são comuns; opera-se, em seguida, sobre as últimas, em caso de possuírem algo em comum com uma outra ordem de ideias. Continua-se a abstração até chegar às ideias simples e universais, encerrando todas as ideias, todos os indivíduos e se negando a uma nova abstração. Estas últimas denominam-se espécies superiores. Todas as ideais abstratas, não perceptíveis pelos sentidos, são designadas pelo termo: segundos inteligiveis, por conduzirem à aquisição dos conhecimentos. Quanto a faculdade reflexiva considera estes inteligíveis abstratos e deles procura retira a forma (ou ideia) verdadeira do ser, deve o entendimento combinar algumas dessas ideias com outras ou delas as separar. Serve-se então de um modo de demonstração fornecido pela razão. Certo em seus resultados, chega assim a obter uma forma do ser que será perfeitamente verdadeira e que estará de acordo com a realidade. Mas para aí chegar, deve guiar-se por um bom sistema de regras, tal como o que acabamos de mencionar. 
A definição dos primeiros inteligíveis como um tipo de carimbo que se adapta à todas as impressões que ele produz pode facilmente ser tomada como uma descrição da asabiyyah, carimbo que deixa sua impressão em todos os grupos sociais destinados ao sucesso e ao desenvolvimento. Segundo o autor de Os Prolegômenos, há uma lógica presente nos primeiros inteligíveis que é fruto dos ensinamentos presentes nos "livros de Lógica” (KHALDUN, 1960, p. 227). Para ele, essa regra indica que a "operação conceptiva processa-se primeiramente e que a de julgar é uma consequência desta última" (KHALDUN, 1960, p. 227). Logo, é possível afirmar que asabiyyah e os primeiros inteligíveis são operações conceptivas, pois funcionam como uma espécie de fundamento para a compreensão e o julgamento de determinados assuntos. Enquanto os primeiros inteligíveis estão presentes nas ideias abstratas, a asabiyyah está presente nos grupos sociais.

Paradoxalmente, enquanto crítica os filósofos ao afirmar categoricamente que os mesmos estão errados por defenderem que "a felicidade (suprema) consiste em obter a percepção de todos os seres" (KHALDUN, 1960, p. 227) e atribuírem a existência "de todos os seres à primeira inteligência” (KHALDUN, 1960, p. 229) - para Ibn Khaldun além dessa inteligência há "diversas ordens de seres criados por Deus" (KHALDUN, 1960, p. 229) -, ele utiliza a lógica produzida dentro da tradição filosófica para estabelecer conceitos como asabiyyah, presentes na formação e declínio dos impérios.

Aqui fica evidente que Ibn Khaldun era um homem dividido vivendo em um mundo dividido. As duas formas de pensar, filosófica e teológica, que ele, respectivamente, critica e admira, se traspassam no texto. Em função disso, o conceito "primeiros inteligíveis" é algo com características muito semelhantes às do texto sagrado. É uma regra que Ibn Khaldun considera de certa forma eterna, ou seja, fora do real, e comum a todas as sociedades.

Além dessa característica, há também algo que atravessa o texto e está vinculado à qualidade do que está escrito. O livro sagrado (Alcorão) se propõe como a narrativa verdadeira e correta que da à língua árabe seu "caráter sacral" (AL-JABRI, 1999, p. 56). Ele é a regra gramatical, moral e lógica. Todas as outras ou são subprodutos dessa correção ou então estão equivocadas.

De certa forma, em Os Prolegômenos, o Alcorão, por ser considerado um texto sagrado, carrega em si a força do irretocável e torna-se assim o inevitável ponto de 
chegada para qualquer tese que venha a ser apresentada pelo autor. Em razão disso, Ibn Khaldun sempre recorre ao Alcorão para validar suas opiniões. Isso acontece principalmente em razão do próprio texto corânico do versículo citado acima afirmar que não há "mudanças" ou "variações na Lei de Deus". Logo, se não há alterações, a busca pela verdade deve ser baseada sempre no texto sagrado.

Outro trecho do Alcorão utilizado por Ibn Khaldun é: "E não invoqueis, à semelhança de Deus, outra divindade, porque não há mais divindades além d'Ele. Tudo perecerá, exceto o Seu rosto, Seu é o juízo, e a Ele retornareis!". Esse texto (Alcorão $28: 88)^{74}$ é utilizado no encerramento do capítulo 46 da terceira parte do segundo tomo de Os Prolegômenos. Nesse ponto da obra, Ibn Khaldun explica como um império primeiro expande suas fronteiras e depois vai se encolhendo até desaparecer. Para o autor, essa é a prova de que mesmo os mais imponentes e gigantescos impérios são transitórios e as únicas coisas que permanecem são Deus e o Alcorão. Todo é resto é moído pela roda da vida. Surge, cresce, atinge seu ápice, apresenta problemas e desaparece. Há, para ele, um processo natural que inevitavelmente condena todas as sociedades ao desaparecimento.

Ibn Khaldun acredita que os seres humanos são animais sociais, mas de uma maneira diferente da visão aristotélica. Segundo ele, Deus permitiu que humanos tivessem entre suas habilidades a razão empírica, ou como ele mesmo cita em $O s$ Prolegômenos, um intelecto baseado na experiência - "experimental intellect" (KHALDUN, 1967, p. 783) no texto de Rosenthal e "inteligência experiment Sua cosmovisão se constrói portanto a partir da decadência da civilização islâmica e de um mundo em profunda instabilidade.al” (KHALDUN, 1959, p. 380-381) em Khoury. Essa razão aliada à fortitude moral levará determinados grupos sociais à construção de grandes impérios e à vida citadina, onde o trabalho vai se estabelecer, através da agricultura, e depois se ampliar em profissões cada vez mais especializadas em razão do crescimento do comércio e do surgimento dos bens de luxo. Esse sucesso é o germe da destruição dessa mesma sociedade, pois quanto mais ela se urbaniza, mais seus indivíduos se distanciam da asabiyyah e os governantes do justo comando.

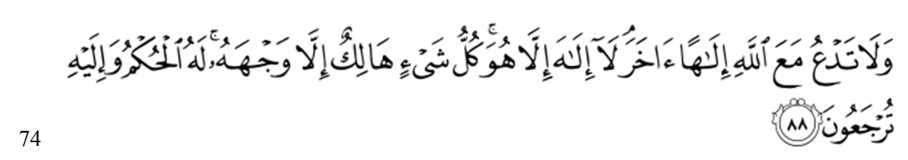


As ideias econômicas de Ibn Khaldun estão todas apresentadas dentro dessa moldura corânica. Sua função na sociedade, segundo Os Prolegômenos, é gerar o ordenamento no qual o mundano repete-se numa ciranda de surgimento, auge e decadência. Elas são a base de uma cosmovisão que evidencia, ao mesmo tempo, o plano falível daquilo que é humano em contraposição à correção do que é divino. 


\section{CONCLUSÃO}

Em parte devido ao imperialismo, todas as culturas são mutuamente imbricadas; nenhuma é pura e única, todas são híbridas, heterogêneas, extremamente diferenciadas, sem qualquer monolitismo. (SAID, 2005, p. 28)

Edward W. Said, Cultura e Imperialismo

Assim como Aristóteles pacientemente estudou a natureza e a realidade à sua volta e, a partir delas, deu passos importantes em direção às mais variadas áreas da ciência e do conhecimento. Séculos depois, seguindo o caminho desse esse racionalismo aristotélico que busca analisar e compreender o mundo, Ibn Khaldun tentou superar o pensamento grego e latino ao produzir, a partir do instrumental produzido por essa tradição, uma cosmovisão capaz de responder às questões socioeconômicas de sua época sob um enquadramento corânico e, portanto, moralista.

O autor de Os Prolegômenos, igualmente a outros pensadores árabes, como Avicena, Averróis e Al-Fārābī, buscou harmonizar seus textos e análises com a religião profética do islã (ATTIE FILHO, 2002, p. 199). O pensamento khalduniano surge portanto da conciliação entre a analise silogística da realidade e a moldura que a religião de certa forma lhe impõe.

Em razão disso, a vida e o mundo de Ibn Khaldun, apresentados aqui no breve panorama histórico e na biografia do autor de Os Prolegômenos presentes no Capítulo 1, foram o ponto de partida desse trabalho em direção ao tema central de nossa investigação: como o contexto social - marcadamente religioso e politicamente instável - aparece e influencia as teorias econômicas presentes na obra khalduniana e assim produz nela uma cosmovisão.

A pesquisa nos capítulos sobre temas econômicos como a valoração do trabalho, mão de obra, divisão do trabalho, lucro, comércio, oferta, demanda e pressão inflacionária serviram para evidenciar a construção de um pensamento que conjuga certo ethos econômico constitutivo das sociedades muçulmanas com a doutrina religiosa islâmica saída da escola de jurisprudência malikita. Ela indica primordialmente que não é possível separar o pensamento produzido em língua árabe de seu contexto cultural, 
político, social e civilizacional, pois isso equivaleria a desfigurar sua identidade e a desvirtuar o curso real de sua evolução (AL-JABRI, 1999, p. 80).

Essa análise acabou apontando que o saber exposto em Os Prolegômenos é fruto de um exercício de observação e compreensão da natureza, das sociedades e dos indivíduos que ganhou força e método após Aristóteles e a tradição filosófica da Antiguidade chegarem a pensadores árabes, como Ibn Khaldun. Logo, concordamos com aqueles para os quais o pensamento em língua árabe não é apenas um simples acréscimo à filosofia grega da época helenística, isto é, espécie de fenômeno isolado que teria ocorrido dentro da sociedade árabe-islâmica (AL-JABRI, 1999, p. 80). Ao contrário, em Os Prolegômenos, a terminologia aristotélica, a lógica e o pensamento filosófico são moldados à religião muçulmana e tornam-se, em razão dessa mistura singular, ocorrida em língua árabe, um importante trecho da contínua difusão transcultural da história do conhecimento humano.

Portanto, o olhar presente em Os Prolegômenos acaba moldado pelo ethos do período e da região onde viveu Ibn Khaldun, o qual busca fazer o mesmo que Aristóteles quando este, fugindo de desventuras acadêmicas, refugiou-se na ilha de Lesbos, onde, a convite do amigo Teofrasto, dissecou, analisou, documentou e estudou animais. Esses trabalhos de campo de Aristóteles, hoje praticamente esquecidos, produziram seu Historia animalium, obra que para muitos funda a biologia (LEROI, 2014, p. XIII). Já Ibn Khaldun, ao observar com lupa semelhante a história dos povos muçulmanos, produz uma cosmovisão que congrega, entre outras coisas, a defesa de governos sóbrios e atentos às práticas religiosas à análise pragmática da realidade e dos desafios que essa análise impõe, tudo isso culmina na fabricação de um texto que para muitos é precursor da sociologia, de um novo fazer histórico (BAALI, 1988, p. 32-37) e que arrisca passos audaciosos e pioneiros na área de economia, apesar de Ibn Khaldun não poder ser considerado um economista stricto sensu (BAALI, 1988, p. 77-88).

Os Prolegômenos, por suas peculiaridades, possibilita entender aquilo que o historiador Richard W. Bulliet chamou de civilização islamo-cristã em sua obra The case for islamo-christian civilization e que nós preferimos chamar aqui apenas de civilização. $\mathrm{O}$ texto de Ibn Khaldun aponta para uma narrativa maior, que está inserida na história do conhecimento - conhecimento este que pode ser definido como a 
capacidade de um indivíduo, um grupo ou uma sociedade de resolver problemas e de antecipar mentalmente as ações necessárias para tal.

Ao nos debruçarmos sobre Os Prolegômenos, o que percebemos é a capacidade de pensadores como Ibn Khaldun de produzir conceitos que ao mesmo tempo resumem e ampliam uma época, pois consolidam o conhecimento acumulado pelo processo de superposição de ideias através dos tempos, e, em razão disso, transmitem noções de valor global e, muita vez, atemporal.

Ibn Khaldun analisa vários fenômenos econômicos de seu tempo para demonstrar que sua tese a respeito dos ciclos de surgimento e decadência dos impérios estava ancorada na observação da realidade da mesma maneira que respondia a uma concepção religiosa de organização e constituição das sociedades. Assim, tal trabalho paradoxalmente não ocorre fora da tradição filosófica apesar do fundo religioso e da crítica que Ibn Khaldun faz à falsafa.

Quando essa visão de "uma cadeia de eventos que obedece uma lei da eterna rotação", conforme escreveu Sêneca (1838, p. 424, tradução nossa), surge nos escritos de Ibn Khaldun, ela está ganhando mais um capítulo de sua narrativa ${ }^{75}$. Obviamente, isso não significa que determinadas ideias econômicas se transportaram diretamente de textos gregos e latinos para Os Prolegômenos e, depois, ressurgiram em trabalhos futuros na Europa. Porém, também não é possível negar no texto khalduniano a existência de um processo de construção do conhecimento que, apesar de suas peculiaridades, segue firme no seu papel de companheiro de viagem (RENN, 2012, p.32) da história humana e de sua tentativa de compreensão dos eventos sociais e econômicos. Sua obra está dentro de uma tradição da qual fazem Al-Fārābī, Avicena, Averróis, Arabus, Aristóteles e tantos outros.

Foi para tentar tornar um pouco mais evidente tal percurso que analisamos algumas das ideias presentes na obra de Ibn Khaldun, principalmente aquelas relacionadas à área de economia e à cosmovisão que elas produzem. $\mathrm{O}$ autor de $O s$ Prolegômenos aponta que o trabalho é fato essencial da vida em comunidade e base de

\footnotetext{
${ }^{75}$ Possivelmente esses saberes surgidos na Antiguidade (oriental e grega) presentes no texto de Ibn Khaldun seguiram caminho até encontrar outros textos de autores como Machiavelli, Campanella e Vico, quando esses escreveram sobre ciclos históricos em tempos que sucederam o autor de Os Prolegômenos. A semelhança, nesse caso, é possivelmente resultado da utilização das mesmas fontes, ou seja, o pensamento de Ibn Khaldun possuía uma moldura saída da Antiguidade e reconfigurada no mundo árabe que seria utilizada por outros pensadores tempos depois.
} 
todo benefício dos indivíduos que dela fazem parte (KHALDUN, 1959, p. 277). Para ele, não há sociedade sem trabalho, o qual, por sua vez, produz a formação de redes entre profissionais, que se inter-relacionam ao se tornarem necessários uns aos outros. Dessa forma, o trabalho é peça fundamental para a manutenção da teia social. Sem ele, ou quando ele não é mais algo que se almeja, o que temos é o início da decadência. Ibn Khaldun acredita que estão fadadas ao declínio as sociedades nas quais trabalhar deixa de ser algo atrativo por não produzir benefícios aos trabalhadores (KHALDUN, 1959, p. 320).

Não por acaso, Ibn Khaldun percebe e destaca a importância de uma teoria valor-trabalho, ou seja, o autor de Os Prolegômenos aponta para a necessidade de o trabalho ser algo capaz de acarretar benefícios aos trabalhadores, o que só ocorre quando os valores atribuídos aos bens por eles produzidos são justos. A correta valoração do trabalho realizado seria, portanto, fundamental para a manutenção e o progresso da vida em sociedade.

Paradoxalmente, Ibn Khaldun também vê no trabalho a causa da decadência de um império. Quando uma sociedade prospera e acumula riquezas, o governo se acostuma à pompa. Depois acaba adotando políticas fiscais mais duras para contratar uma mão de obra cada vez mais especializada e produtora de um comércio de luxo, o qual é pago com o dinheiro dos impostos. Esse ciclo perverso afasta líderes e trabalhadores da vida simples dos povos autossuficientes e, desta forma, os distancia da asabiyyah (KHALDUN, 1959, p. 88-89). Para Ibn Khaldun, a vida em sociedade leva à especialização e à interdependência; a vida mais próxima da natureza, à autonomia e à virtude.

É desse antagonismo que surge a ideia de história cíclica em Os Prolegômenos e a cosmovisão por trás dela. Se toda sociedade está fadada ao trabalho e todo trabalho à especialização, quando a valoração da produção é feita corretamente, esse acerto gera riqueza, o qual, por sua vez, corrói os governantes e os empurra para a ostentação. Ao acertar na valoração do trabalho, tal sociedade está pavimentando o caminho de seu progresso e sua posterior destruição. Esse sistema fechado foi a maneira que Ibn Khaldun encontrou para colocar a noção de Deus em sua cosmovisão. Em sua análise, a vida em sociedade está condenada a ser provisória. Ele acredita que quando uma economia funciona corretamente, seu sucesso sempre será passageiro porque ele carrega 
dentro de si o germe do comércio de luxo que a destruirá. Em oposição à transitoriedade presente nas relações humanas relacionadas ao trabalho ele coloca o Alcorão, o qual ele crê ser inimitável (KHALDUN, 1960, p. 321) e perfeito (KHALDUN, 1967, p. 583).

Nesse sentido, o conceito de asabiyyah (sentimento de grupo) se opõe ao da especialização da mão de obra. O primeiro é um traço encontrado na vida tribal dos beduínos; o segundo está presente majoritariamente nos grandes centros urbanos. Povos mais próximos da asabiyyah são mais independentes, solidários, justos e virtuosos, em razão disso, têm, segundo ele, maior apreço e obediência à religião; povos onde a mão de obra se especializou e a força de trabalho se ampliou são mais distantes da asabiyyah, mais dependentes uns dos outros e com governantes cada vez mais dados ao luxo. Assim, a vida mais próxima da natureza, ou seja, do mundo que Deus criou, é moralmente mais correta quando comparada à vida nas cidades criadas pelos homens, a qual está sempre fadada à decadência.

Tal separação entre tipos de vida - badawi e hadari - em sociedade serve, na verdade, para criar uma moldura religiosa para as teses que Ibn Khaldun propõe sobre a economia das grandes cidades. Ele indica que impérios que levam uma vida mais próxima da asabiyyah tendem a durar mais. Portanto, o bom desempenho econômico de uma sociedade estaria profundamente vinculado à maneira com a qual essa sociedade encara e se relaciona com a religião (MOHAMED, 2017, p. 28).

Além disso, Ibn Khaldun hierarquiza a realidade sempre partido do mais simples para o mais complexo (MOHAMED, 2017, p. 30). O resultado dessa hierarquização vai da concepção de importância da valorização correta da mão de obra, da qual tudo emana e que tudo destrói, passa pela sofisticação das relações entre os trabalhadores das cidades e vai até a defesa de um Estado forte e regulador, mas paradoxalmente sóbrio, isto é, capaz de cobrar o mínimo possível de impostos.

O esforço analítico de Os Prolegômenos sobre a construção das sociedades, partindo do simples para chegar ao mais complexo, ou seja, do nomadismo dos badawi para a vida urbana dos hadawi, indica que a força do dinamismo constituidor da asabiyyah estaria profundamente presente nos grupos sociais economicamente menos desenvolvidos enquanto a decadência seria parte inequívoca das grandes e luxuosas cidades (LACOSTE, 1966, p. 126-127). Esse mecanismo aponta que, para Ibn Khaldun, o poder temporal perde força e caminha para seu fim ao se distanciar do âmbito 
espiritual. Ele também revela que as forças econômicas não são fundamentalmente o problema. Elas apenas fazem parte de uma arquitetura social que, em última instância, sempre se repete por uma questão de fundo moral, pois coloca o luxo acima do espiritual e daquilo que é realmente necessário. Para ele, os governantes não buscam simplesmente a riqueza pela riqueza. Na verdade, o comércio de luxo é uma forma equivocada de conquistar e demonstrar prestígio que apenas indica decadência e equívoco, pois tudo aquilo que é "necessário por natureza deve passar antes do supérfluo" (KHALDUN, p. 103, 1958), isto é, tudo aquilo que é natural precede, em importância, o que é luxo. Logo, os governantes não buscam as benesses do luxo pelo luxo em si, o que os leva para esse comportamento é um problema de fundo moral. Para Ibn Khaldun, não é a ganância que alimenta o comércio de luxo, mas a procura pelo prestígio, as facilidades e o status que o luxo representa. Evitar tal corrupção só é possível através da proximidade e devoção aos preceitos do texto corânico e do mundo espiritual, mesmo para um autor racional e de procedimentos materialistas ao tratar das coisas do dia a dia (RABI, 1967, p. 32) como é Ibn Khaldun.

Em razão disso, é possível afirmar que o Alcorão, segundo Ibn Khaldun, é a pedra de toque para tudo aquilo que socialmente é verdadeiro, correto e justo. No entanto, inevitavelmente a relação entre os indivíduos, que também carregam em si essa mesma dualidade, e o texto corânico se enfraquece conforme a sociedade se sofistica e as relações econômicas ganham complexidade. Esse é o principal motivo para a razão (falsafa) ser utilizada como uma ferramenta que jamais será o objetivo do pensamento khalduniano. Sua meta é religiosa e visa sempre fundamentar uma compreensão da realidade regida por seus próprios princípios, por sua própria problemática e recheada de contradições (AL-JABRI, 1999, p. 72).

Essa é a fórmula encontrada pelo autor de Os Prolegômenos para lidar com os infortúnios de sua época. Ele ampara sua teoria na imutabilidade e infalibilidade do texto sagrado como forma de responder às constantes e perturbadoras transformações sociais e às repetidas imprecisões administrativas praticadas pelas autoridades. Tal refúgio religioso responde por conseguinte à contínua instabilidade e efemeridade do poder, principalmente na região do Magreb, e às catástrofes produzidas pela peste negra no mundo. Dado isso, sua análise de todo e qualquer quadro econômico busca apresentar uma realidade cíclica que impõe mecanismos fundadores de uma estrutura fadada à degradação social produzida pelo inevitável progresso e o distanciamento dos 
preceitos religiosos que ele produz. É nesse peculiar entendimento da realidade social que surge uma teoria valor-trabalho. Para Ibn Khaldun, paradoxalmente um homem culto e sempre inserido nos mais altos círculos de poder, as frivolidades do luxo eram supérfluas e potencialmente destrutivas. Portanto, ao defender a valoração correta dos produtos e serviços em razão da quantidade de trabalho que eles receberam (RABI, 1967, p. 36), Ibn Khaldun impõe às relações econômicas a força da sua moral religiosa. Para ele, somente as sociedades com mais asabiyyah são capazes de dar o valor correto aos produtos e serviços comercializados dentro delas. Ele também concede aos trabalhadores uma nova e crucial posição dentro da história. Ao afirmar que a “aquisição é o preço do trabalho do homem" (KHALDUN, 1959, p. 277) e unir a esse conceito a noção de que a oferta e a demanda são cruciais para determinar os preços e, portanto, os ganhos dos trabalhadores (KHALDUN, 1959, p. 316), Ibn Khaldun colocase inequivocamente em uma história do pensamento econômico mais ampla e na origem de importantes e atuais noções econômicas (BALOGLOU, 2012, p. 72).

Em grande parte, em razão dessas singularidades, o texto de Ibn Khaldun aponta para as inúmeras possibilidades que trabalhos feitos séculos atrás em língua árabe podem apresentar aos pesquisadores atuais. Ele, além da "novidade" de interpretar elementos culturais de maneira materialista (RABI, 1967, p. 33), permite a compreensão socioeconômica de um período histórico que muito pode nos ensinar. Seu texto nos apresenta como "inovador" ao retratar uma sociedade na qual o trabalho não é apenas um fator de identidade social (UEBEL; ROBERTSON, 2004, p. 1), mas um dos principais mecanismos para o surgimento de cidades urbanizadas onde a produção se dá a partir da cooperação de trabalhadores cada vez mais qualificados. Para ele, o trabalho é criador de cidades. Daí sua importância.

Nesse sentido, a análise da obra feita aqui pretende servir como argumento para a defesa de uma outra história do conhecimento, mais ampla e formada pelo estudo dos pensadores árabes e das práticas comerciais e religiosas desse povo. É preciso um esforço para reinserir Ibn Khaldun na academia. Uma obra como Os Prolegômenos não pode mais ficar na periferia das ideias centrais. Ela é um importante capítulo da construção do conhecimento que ganharia força nos séculos XV, XVI e XVII, tanto para o mundo cristão quanto para o mundo muçulmano, porque apresenta claramente a tese segundo a qual não apenas fatores econômicos, mas alguns elementos culturais, 
nesse caso a religião, são parte fundamental da construção e manutenção políticoeconômica de uma sociedade.

O texto khalduniano nos mostra o quanto ideias são construções sociais em constante propagação. Portanto, enganam-se aqueles que transformam a vitória de Carlos Martel, na batalha de Tours e Poitiers, em 732 - a qual é para muitos historiadores o ponto final da expansão do islã e do pensamento árabe na Europa ${ }^{76}$ o fim das trocas de conhecimentos. Ali pararam as armas, não as ideias. Há nelas um mecanismo que lhes é subjacente: são amálgamas incessantes e ganham complexidade ao se alastrar. Em razão desse mecanismo que lhes é intrínseco, a expressão "pensamento ocidental" deveria dar lugar à terminologia correta, qual seja: "história do pensamento das civilizações humanas". Em muito, o texto de Ibn Khaldun é prova disso.

Em sua obra é possível ver que em razão de sua intrínseca capacidade de correr o mundo junto ao comércio e à expansão dos povos, as ideias não podem ser aprisionadas a uma determinada região ou população. Tal prejulgamento que nos leva a entender uma determinada civilização a partir de um exclusivismo geográfico, mesmo quando não há nessa geografia nenhuma barreira natural que podemos chamar de intransponível. Até mesmo o inóspito deserto do Saara foi palco de inúmeras rotas comerciais, apesar da inegável dificuldade de atravessá-1o ${ }^{77}$. Em muito, o livro de Ibn Khaldun é fruto desses itinerários mercantis.

\footnotetext{
${ }^{76}$ Para Bernard Lewis, em seu livro $A$ descoberta da Europa pelo islã, à página 3, afirma que tal batalha sequer foi considerada decisiva pela historiografia árabe. Segundo ele, "a tradição muçulmana reflete uma visão diferente dos feitos de Carlos Martel e dos resultados da Batalha de Tours e Poitiers. Os árabes têm uma rica bibliografia historiográfica, celebrando, com detalhes afetuosos, as fases sucessivas da jihad, a guerra santa pela fé contra os infiéis, registrando com meticulosa honestidade tanto os reveses quanto as vitórias dos conquistadores. Eles estavam, evidentemente, bastante conscientes de que, na França, haviam alcançado os limites de sua expansão rumo ao Ocidente". Lewis escreve que a batalha é "apresentada como um combate de importância relativamente pequena".

${ }^{77}$ A cidade de Timbuktu, que fica na região central do Mali, na entrada do Saara, tinha no século XIV o dobro do tamanho de Londres. Era um grande centro de cultura controlado pelo poder central do rei Kankan Mūsā (ou Mansa Mūsā). Portanto, no mesmo momento em que parte do mundo, principalmente a Europa, sofria com ondas de frio, extrema pobreza, epidemias e revoltas, o muçulmano Mansa Mūsā fez um histórica e quase mitológica peregrinação até a cidade de Meca. Sua caravana era formada por centenas de pessoas e levava um enorme carregamento em ouro. Timbuktu, a cidade que ele controlava, era tomada por comerciantes árabes que vendiam sal, produtos têxteis e vários tipos de metais. O local era um dos pontos principais de uma lucrativa rota transaariana de comércio e ideias. Floresceu Do século XIII até o XVI porque se localizava na confluência de duas importantes rotas de comércio daquela época: o Saara, de onde chegavam as caravanas vindas do norte; e o rio Níger, que era rota para o transporte de ouro e escravos vindos do restante da África Ocidental. Lá, as famosas livrarias e manuscritos de Timbuktu representavam um ponto de troca de conhecimentos. Um exemplo dessa importância está na
} 
Da mesma forma que muitas ideias foram transmitidas dos judeus e egípcios aos fenícios e destes para outras populações e tradições na África e na Europa, idêntica história ocorreu com as ideias produzidas pela civilização islâmica.

$\mathrm{Na}$ época de Muhhammad, o pensamento existente resultava dessa fusão de ideias, muitas delas produzidas dentro da língua grega. Eram reverberações de conceitos presentes nos textos de Homero, Sófocles, Tucídides, Platão e Aristóteles; outras, fruto do universo da língua latina e da mente de figuras do porte de Virgílio, Lucrécio, Cícero e Tácito; e também todas as que as precederam e as sucederam, como é o caso das ideias criadas por fenícios, judeus e egípcios. Assim, o mundo muçulmano, em razão de seu crescimento e de seu local de nascimento, angariou contribuições conceituais de inúmeros povos. Portanto, da mesma forma que pensadores árabes beberam em fontes gregas, isso também foi feito pelos judeus, que uniram o pensamento hebraico ao mundo helênico, como é possível ver em textos que vão de Filo de Alexandria, passam por Maimônides, Hasdai Crescas e Espinosa e chegam a Moisés Mendelssohn, Julius Guttmann e tantos outros.

Com a criação e o crescimento do islã ${ }^{78}$ essa sopa civilizacional ganhou mais um ingrediente: o pensamento em língua árabe. Tamanho evento serviu não apenas para colocar Muhhammad ao lado de figuras como Moisés, Jesus e Paulo, mas também para transportar as ideias de Aristóteles para as obras de Averróis e Ibn Khaldun; as de Hipócrates e Galeno para as de Avicena; as de Maimônides para as de Tomás de Aquino; e as de Cícero para as de João de Salisbury. A pletora de apropriações feitas por pensadores árabes, latinos e hebreus resultou em uma imensa parcela do pensamento que temos hoje. Mais ainda: essa mistura constante não cessa. É possível inclusive afirmar que pensadores modernos como Erich Auebach e Walter Benjamin, que trouxeram para seus trabalhos acadêmicos a tradição da interpretação talmúdica, e Mohammed Abed al-Jabri, que buscou praticar a racionalidade dentro e a partir da

posição central dedicada a esse local no Atlas Catalão atribuído ao cartógrafo judeu da ilha de Mallorca Abrão Cresques (1325-1387).

${ }^{78}$ Segundo o professor de Estudos Islâmicos em Yale, nos EUA, Dimitri Gutas, “determinadas condições materiais prepararam um pano de fundo contra o qual um movimento de tradução poderia ter lugar e florescer foram estabelecidas por dois eventos históricos importantes: as primeiras conquistas árabes através do período omíada e a "revolução abássida que culminou em 134/750 (...) O significado histórico das conquistas árabes dificilmente pode ser superestimado. O Egito e o Crescente Fértil se reuniram com a Pérsia e a Índia politicamente, administrativamente e, o mais importante, economicamente, pela primeira vez desde Alexandre o Grande, tal união duraria muito mais tempo do que a sua breve vida. (...) Isso permitiu o fluxo livre de matérias-primas e produtos manufaturados, produtos agrícolas e itens de luxo, pessoas e serviços, técnicas e habilidades, idéias, métodos e modos de pensamento" (GUTAS, 1998, p. 11-12). 
tradição árabe e não fora dela, seguem em um caminho que remete aos textos de pensadores como Maimônides e Ibn Khaldun.

A Europa, por sua vez, importou práticas comerciais muçulmanas em razão do crescimento, durante a Idade Média, do comércio entre Veneza e Gênova e os povos do Levante - região entre a Europa e a Ásia onde hoje estão os territórios da Síria, Jordânia, Israel, Palestina, Líbano e Chipre. Depois, com a vitória na guerra naval de Chioggia (1378-1381), Veneza derrotou Genova e assumiu o monopólio do comércio no Oriente Médio. Cresceram os lucros venezianos e também a cidade passou a importar cada vez mais o conhecimento em língua árabe.

Além dessa ponte entre a civilização muçulmana e a Europa, as ideias desse período também percorrem outros caminhos, entrando no Velho Continente por regiões como a Sicília e a Espanha, por onde aconteceram "intercâmbios materiais e culturais" (TALBI, 2010, p. 77) que "nunca foram interrompidos" (TALBI, 2010, p. 77).

O comércio e as expansões demográficas agiram como uma espécie de trilho por onde a locomotiva carregada com as ideias se moveu do mundo árabe para outras regiões. Não só produtos, mas pessoas e ideias seguiram esse mesmo fluxo. Muitas delas encontraram refúgio nas mais brilhantes mentes europeias. Os conceitos presentes na obra de Ibn Khaldun possivelmente reverberaram em trabalhos do Velho Continente da mesma forma que as ideias presentes na Política de Aristóteles chegaram em segunda mão ao autor de Os Prolegômenos.

Essa influência foi importante principalmente na Itália, o que dá à Renascença, além de sua conhecida vinculação com o pensamento da Antiguidade clássica, um inegável toque árabe e hebraico. Tanto é assim que Jacob Burchardt, em sua obra The Civilization of the Ranaissance in Italy, afirma que, durante a Renascença, os estudos orientais ganham proporções consideráveis. Obras em árabe e hebraico de pensadores como Avicena e Maimônides foram traduzidas e estudadas por figuras como Pico dela Mirandola, Hieronimo Ramusio e Andreia Mongaio (BURCKHARDT, 2002, p. 137138). A peculiaridade histórica e a amplitude dos textos de Ibn Khaldun apontam para um pensamento que, mais tarde, reapareceria na Renascença. Portanto, esta pesquisa não pretende defender uma possível presença do pensamento de Ibn Khaldun em clássicos da economia europeia, o que o texto de Os Prolegômenos evidencia com sua inegável existência é uma compreensão que antagoniza um eurocentrismo que pretende 
nos oferecer uma história universal da razão ancorada na Grécia (MAMDANI. 2012, p. 1) e um pensamento econômico que teria surgido na Renascença e no Iluminismo escocês.

No caso mais específico de Os Prolegômenos, sabemos que ele foi amplamente influente na elite otomana e acabou, através desses, sendo recebida por outros pensadores europeus. Alguns historiadores, principalmente Taqi al-Din alMaqrizi (1364-1442) e Ibn Taghribirdi (1410-1470), utilizaram os conceitos de Ibn Khaldun para falar da formação e do declínio de um determinado poder. Al-Maqrizi, que foi seu aluno e se tornou um dos principais nomes do movimento historiográfico do Egito dos mamelucos na primeira metade do século XV (IGGERS; WANG, 2002, p. 97).

Depois, por volta de 1730, Perizade iniciou a tradução de Os Prolegômenos para o turco (MAHDI, 2016, p. 299). A partir de então, historiadores otomanos do século XVIII, que viam em Ibn Khaldun um autor profundamente reformista, utilizaram amplamente o texto de Os Prolegômenos para tentar entender melhor a crise que eles estavam enfrentando (CAMPO, 2009, p. 335). Destarte, as explicações de Ibn Khaldun sobre os declínios de poderosas dinastias acabaria se espalhando pelos pensadores do Império Otomano. Na Europa ocidental, o francês Silvester de Sacy, por volta de 1800, foi o primeiro a produzir uma tradução de Os Prolegômenos. Essa versão só seria concluída por seu discípulo E. Quatremère alguns anos depois, sendo publicada em 1863 (KHALDUN, 1936, p. 85).

Portanto, apesar de não termos evidência de que o trabalho de Ibn Khaldun tenha sido traduzido nos séculos XV e XVI na Europa ocidental, muitas das ideias nele presentes certamente atravessaram o Mediterrâneo nas mãos e mentes dos "políticos para os quais o Mediterrâneo era o palco de suas ambições" (PERSRAM, 2008, p. 43) ${ }^{79}$.

\footnotetext{
${ }^{79}$ Não é absurdo afirmar que o conceito de asabiyyah presente em Os Prolegômenos apresenta algumas semelhanças com a ideia de virtù presente nas obras de Maquiavel. O príncipe dotado de virtù está muito perto do califa dotado de asabiyyah. As obras desses dois autores também apresentam modelos para manter um Estado estável pelo maior tempo possível e com mão forte. São ambos manuais de como governar bem e manter o poder centralizado. Maquiavel bebe da mesma fonte que Ibn Khaldun. Suas obras possuem vinculações com os mesmos espelhos de príncipe (specula principum) e fabulários políticos presentes nas literatura árabe e persa clássicas. Tais obras, também conhecidas na Europa como Fürstenspiegel, produziram as bases para a teoria da "Staatsraison" (razão de Estado) presente tanto em Os Prolegômenos quando nas obras de Maquiavel e também para a visão de realpolitik das duas obras. Em Ibn Khaldun, a política é o encontro dos fatores locais com as leis históricas universais que atuam sobre qualquer sociedade.
} 
Assim como é possível encontrar inúmeras semelhanças entre a Cidade Perfeita de Ibn Khaldun (1959, p. 134) e a cidade ideal (Al-Madīnat al-fādilah) de Al-Fārābī, a De civitate Dei (A cidade de Deus) de Agostinho de Hipona, a Cidade do Sol de Tommaso Campanella, o mito da cidade de Atlântica presente nos diálogos de Platão Timeu e Crítias, a Nova Atlântida de Francis Bacon e a República de Oceana de James Harrington. Também é possível encontrar pistas do pensamento de Ibn Khaldun em trabalhos como o do historiador Bernard Lewis, o qual foi um dos primeiros intelectuais britânicos a ter acesso aos arquivos do Império Otomano e aos textos dos historiadores daquela região (LEWIS, 1993, p. 89). De certa forma, seu trabalho foi influenciado por Ibn Khaldun através dos arquivos que Lewis consultou em Istambul, muitos deles apegados construídos no mesmo entendimento que o autor de Os Prolegômenos tinha do mundo muçulmano. O próprio Lewis afirma que historiadores como o fancês E. Gautier, o egípcio Ahmad Fu'ad Al-Ahwani, o geógrafo franco marroquino Yves Lacoste e os discípulos de Durkheim e Breysig estudaram, criticaram, elogiaram e difundiram as ideias presentes em Os Prolegômenos (LEWIS, 1993, p. 89) ${ }^{80}$.

Paradoxalmente, a inegável atualidade do texto de Ibn Khaldun, é muita vez estrangeira à história recente do norte da África, onde o autor nasceu e viveu muitos anos. Algumas de suas ideias reapareceram naquela região em ajustes econômicos impostos pelo Banco Mundial e o FMI a países como Argélia, Tunísia e Egito, após a década de 1950 (WEISS, 1995, p. 29). Planos para tornar as economias dessas nações mais favoráveis ao mercado (market-friendly) ganham aspecto de cacofonia dissonante e fora de lugar, principalmente depois de um olhar mais atento às teses defendidas pelo autor de Os Prolegômenos, para quem as dinastias e suas respectivas economias são resultado de um processo interminável e terão mais ou menos tempo de vida ${ }^{81}$ em razão de sua capacidade de incentivar o comércio, manter vivo o sentimento de asabiyya e adotar políticas fiscais que beneficiem o empreendedorismo.

\footnotetext{
${ }^{80} \mathrm{Na}$ atualidade, Ibn Khaldun é influente em muitas escolas de sociologia e também em trabalhos de intelectuais como Marshall Hodgson (1922-1968), Bruce B. Lawrence e Richard W. Bulliet.

${ }^{81}$ As teorias de surgimento e declínios de dinastias presentes em Os Prolegômenos são consideradas extremamente atuais por muitos intelectuais contemporâneos. Prova disso é que elas foram utilizadas pelo famoso economista vencedor do Prêmio Nobel Paul Krugman ("The Decline of E-Empires", The New York Times, 25 de agosto de 2013) para explicar como grandes corporações do setor tecnológico obedeciam ciclos de crescimento iguais aos descritos em Os Prolegômenos. É interessante ver como as ideias de Ibn Khaldun atingem atualmente tanto um importante economista da direita norte-americana (Arthur Laffer) quanto um economista vinculado à esquerda do mesmo país (Paul Krugman).
} 
Portanto, muito antes desses pacotes econômicos, Ibn Khaldun já havia apontado que quando a carga de impostos excede a capacidade contributiva da sociedade, a arrecadação e a produtividade caem e o governo caminha para seu fim (KHALDUN, 1959, p.87-89).

Nosso entendimento é que a trajetória de muitas ideias presentes em Os Prolegômenos prosseguiu e, apesar dos percalços comuns a todo conhecimento humano, chegou, em parte, ao debate atual. Essa complexidade nos parece mais coerente com a história do que aquela apontando para a Europa como principal, e muita vez única, fonte do saber no qual se fundamenta o debate econômico atual. A análise de Os Prolegômenos ajuda a esclarecer que Ibn Khaldun "descobriu inúmeras noções gerais de economia séculos antes de seus nascimentos oficiais" (BALOGLOU, 2012, p. 72, tradução nossa). Seu trabalho é resultado de um processo de produção de saber em economia que não teve o "great gap" (SCHUMPETER, 1954, 74) de 500 anos do qual fala Joseph Schumpeter em sua obra History of economic analysis ${ }^{82}$.

Um caminho futuro seria trabalhar para tornar mais claro que trajeto algumas das principais ideias do pensamento produzido em língua árabe percorreram desde os séculos XIV e XV até os nossos dias. Esse esforço pode abrir uma janela para entender melhor o processo de formação, funcionamento e autorregulação das redes de conhecimento. Atualmente, inúmeros trabalhos indicam que o conhecimento surge e se auto-organiza de uma maneira muito similar ao de um ecossistema ${ }^{83}$. Estudar as obras de Ibn Khaldun e outros pensadores árabes pode ser um caminho para pavimentar melhor o tortuoso percurso do conhecimento e assim compreender melhor as ideias econômicas atuais.

\footnotetext{
82 Joseph Schumpeter, Arnold Toynbee e vários outros intelectuais ocidentais preferem tratar Ibn Khaldun como um gênio sem antecessores (TOYNBEE, 1935, p. 322) e predecessores (SCHUMPETER, 1993, p. 132). Porém, nossa pesquisa indicou o exato contrário. Ibn Khaldun é resultado de um processo de transmissão de conhecimento não só comum ao mundo muçulmano dos séculos IX, X, XI, XII, XIII e $\mathrm{XIV}$, como essa tradição de ensino em língua árabe foi, nesse mesmo período, marcadamente constante e inovadora.

${ }^{83}$ Isso é o que vemos, por exemplo, nas obras The origins of order: self-organization and selection in evolution, de Stuart A. Kauffman; Organizations evolving, de Howard E. Aldrich; Hidden order: how adaptation builds complexity, de John H. Holland; e The social construction of reality, de Peter L. Berger e Thomas Luckmann. Todos esses autores indicam que agentes históricos individuais, ao analisarem a realidade à sua volta, acabam produzindo conhecimentos que assumem vida própria ao adquirir especificidades, usos e leituras sui generis através de interações complexas e muita vez não lineares. Esse tortuoso caminho das redes do saber foi trilhado pela obra de Ibn Khaldun. Refazê-lo nos ajuda a entender melhor como se dá a construção do nosso conhecimento.
} 


\section{BIBLIOGRAFIA FUNDAMENTAL}

IBN KHALDUN. Os prolegômenos ou filosofia social. Tomo primeiro. São Paulo: Editora Comercial Safady Limitada, 1958.

Os prolegômenos ou filosofia social. Tomo segundo. São Paulo: Editora Comercial Safady Limitada, 1959.

Os prolegômenos ou filosofia social. Tomo terceiro. São Paulo: Editora Comercial Safady Limitada, 1960.

The Muqaddimah: an introduction to history. Princeton: Princeton University Press, 1967.

Paul Geuthner, 1936.

Les Prolégomènes. Deuxième Partie. Paris: Librairie Orientaliste 


\section{BIBLIOGRAFIA COMPLEMENTAR}

AARON, Henry (Ed.); SLEMROD, Joel (Ed.). The Crisis in Tax Administration. Washington D.C.: Brookings Institution Press, 2004.

ALATAS, Syed Farid. Ibn Khaldun: Makers of Islamic Civilization. 5 ed. Nova Delhi: Oxford University Press, 2015.

Nova York: Routledge, 2014.

ABUN-NASR, Jamil M. History of the Maghrib in the Islamic period. Cambridge: Cambridge University Press, 1993.

AL-AZMEH, Aziz. Ibn Khaldûn, an essay in reinterpretation. Budapest: Central European University Press, 2003.

AL-FĀRĀBĪ. Tahsil al sa'ada. Beirute: Editora Ali-Abu Melehem, 1995.

Traité des opinions des habitants de la cité idéale. Paris: Vrin, 1990.

AL-JABRI, M.A. Introdução à crítica da razão árabe. São Paulo: Unesp, 1999.

ALVERNY, Marie-Thérèse d', La transmission des textes philosophiques et scientifiques au Moyen Âge. London: Ashgate Publishing Limited, 1994.

ATIYEH, G. N.; OWEISS, I. M. Arab civilization: challenges and responses. Albany: State University of New York Press. 1988.

ATTIE FILHO, M. Os sentidos internos em Ibn Sina -Avicena. Porto Alegre: Eipucrs, 2000.

2002.

Falsafa: a filosofia entre os árabes. São Paulo. Editora Palas Athena.

ARISTÓTELES. Ética a Nicômaco. Coleção Os Pensadores, Vol. 2. São Paulo: Nova Cultural, 1991.

2002. Vol. II.

Metafísica. Tradução de Giovanni Reale. São Paulo: Edições Loyola,

A Política. 3 ed. São Paulo: Martins Fontes, 2002.

ARISTOTLE. Aristotle: II. Britannica Great Books. Chicago: Encyclopedia Britannica Inc., 1979.

ARKOUN, M. La pensée arabe. Paris: PUF, 1996.

AVERROES. Averroes on Plato's Republic. London: Cornell University Press, 1974.

BAALI, Fuad. Society, state, and urbanism: Ibn Khaldun's sociological thought. Albany: State University of New York Press, 1988.

BACKHOUSE, R. E. The Penguin history of economics. London: Penguin Books, 2002.

BADAWI, A. Histoire de la philosophie en Islam. Paris: J. Vrin, 1972. 
Vrin, 1987.

La transmission de la philosophie grecque au monde arabe. Paris: J.

BAECK, Louis. Ibn Khaldun's Political and Economic Realism. In: Joseph A. Schumpeter, historian of economics: Perspectives on the History of Economic Thought (Laurence Moss, Ed.). London: Routledge, 1996. p. 83-99.

BAFFIONI, Carmela. Ikhwân al-safâ': The Stanford Encyclopedia of Philosophy. Stanford, c2016. Disponível em $<$ https:/plato.stanford.edu/archives/fall2016/entries/ikhwan-al-safa/>. Acesso em: 12.dez.2016.

BALOGLOU, Christos P. The Tradition of economic thought in the mediterranean world from the ancient classical times through the hellenistic times until the byzantine times and arab-islamic world. In: BACKHAUS, Jürgen Georg. Handbook of the history of economic thought - Insights on the founders of modern economics. New York: Springer, 2012, p.7-91.

BARNES, Jonathan. Aristóteles. São Paulo: Edições Loyola, 2005.

BARTHOLO JR., R., Islã - o credo é a conduta. Rio de Janeiro: Imago, 1990.

BAUSANI, A. EI Islam en su cultura. México: Fondo de Cultura Económica, 1980.

BENEDICTOW, Ole J. The black death 1346-1353: The complete history. Trowbridge, Wiltshire: Cromwell Press, 2004.

BÍBLIA. Português. Bíblia Sagrada: Edição Pastoral. São Paulo: Paulinas, 1990.

BISSIO, Beatriz. O conceito de poder na obra de Ibn Khaldun. Disponível em: www.ibeipr.com.br/conteudo/academicos/poderibnkhaldun.pdf (acessado em 13/01/2013).

BLACK, A. The history of Islamic political thought - From the prophet to the present. New York: Routledge, 2001.

BOWERING, Gerhard (Ed). The Princeton encyclopedia of Islamic political thought. Princeton: Princeton University Press, 2013.

BOUM, Aomar; PARK, Thomas K. Historical dictionary of Morocco. Lanham: Rowman \& Littlefield, 2016.

BRODY, David Eliot; BRODY, Arnold R. As sete maiores descobertas científicas da história e seus autores. São Paulo: Companhia das Letras, 1999.

BROWERS, M. L. Democracy and civil society in arab political thought Transcultural possibilities. New York: Syracuse University Press, 2006.

BRUE, S. História do pensamento econômico. São Paulo: Thomson-Pioneira, 2005.

BULliET, R. W. The case for islamo-christian civilization. New York: Columbia University Press. 2004.

BURCKHARDT, J. The civilization of the Renaissance in Italy. New York: The Modern Library. 2002.

CAMPO, Juan Eduardo (Ed.). Encyclopedia of Islam. Nova York: Fact on File, 2009. 
CARDAILLAC, L. (org). Toledo, séculos XII-XIII. Rio de Janeiro: Jorge Zahar, 1992.

CARPEAUX, O. M. História da literatura ocidental. São Paulo: Editora Leya, Vol. I, 2011.

CHEDDADI, Abdesselam. Ibn Khaldûn, l'homme et le théoricien de la civilisation. Mayenne: Editions Gallimard, 2006.

CHEDDADI, Abdesselam. Reconnaissance d'Ibn Khaldün. In: Revista Esprit. Páginas 132-147, n¹1, novembro, Paris, 2005.

CHILDE, V. G. A prehistorian's interpretation of diffusion. In: Independence, convergence and borrowing in institutions, thought and art. Harvard Tercentenary Publications. Cambridge, Mass.: Harvard University Press, 1937. p. 3-21.

CICERO. On the republic. On the laws. The Loeb Classical Library. Cambridge: Harvard University Press, 1928.

CRAIG, Edward (Ed.). Routledge encyclopedia of philosophy. London: Routledge, 1998.

DALE, Stephen Frederic. The orange trees of Marrakesh: Ibn Khaldun and the Science of Man. Cambridge, Mass.: Harvard University Press, 2015. E-Book. ISBN 978-0-674-96765-6.

DE LIBERA, A. A filosofia medieval. Rio de Janeiro: J.Zahar, 1990.

Pensar na Idade Média. São Paulo: Ed. 34, 1999.

ESSID, Yassine. A critique of the origins of islamic economic thought: Islamic history and civilization - vol. 11. New York: Brill Academic Publishers, 1995.

ESPOSITO, John L. (Ed.). The Oxford history of Islam. New York: Oxford University Press, 1999.

FERNANDES, Florestan. A sociologia no Brasil. Petrópolis, Vozes, 1977.

FISCHEL, Walter Joseph. Ibn Khaldun in Egypt: His public functions and his historical research (1382-1406) a study in islamic historiography. Berkeley: University of California Press, 1967.

FLINT, R. History of the philosophy of history: historical philosophy in France, French Belgium and Switzerland. Edinburgh: William Blackwood \& Sons, 1893.

FROMHERZ, Allen James. Ibn Khaldun, life and times. Edinburgh: Edinburgh University Press, 2010.

FURTADO, Celso. Formação econômica do Brasil. São Paulo: Companhia Editora Nacional. 1967.

GARCIN, Jean-Claude. O Egito no mundo muçulmano (do século XII ao início do XVI). In: NIANE, Djibril Tamsir (Ed.). História geral da África IV: África do século XII ao XVI. Brasília: Unesco, 2010. p. 415-444.

GASSET, José Ortega Y. Meditaciones del Quijote. 9 ed. Madrid: Alianza Editorial, 2008. 
GELLNER, E. From Ibn Khaldun to Karl Marx. The Political Quarterly 34:2 (October-December 1961):

GIORDANI, M. C. História do mundo árabe medieval. Rio de Janeiro: Vozes, 1997. História da antigüidade oriental. Rio de Janeiro: Vozes, 1969.

GILSON, E. (Ed.); MAURER. A. A. A history of philosophy: medieval philosophy. New York: Random House, 1962.

GOMBRICH, E. H. A little history of the world. Londres: Yale University Press, 2008.

GOTTFRIED, Robert S. The black death: natural and human disaster in Medieval Europe. New York: The Free Press, 1983.

GRUZINSKI, Serge. Les quatre parties du monde: Histoire d'une mondialisation. Paris: Éditions de La Martinière, 2004.

GUERRERO, R. F. Filosofías árabe y judia. Madrid: Editorial Sintesis, 2001.

GUTAS, D. Greek thought, arabic culture: the graeco-arabic translation movement in Baghdad and early 'Abbāsid society (2nd-4th/8th-10th centuries). London: Routledge, 1998. [ebook]. . Avicena: a metafísica da alma racional. In: KOBUSCH, Theo (org.) Filósofos da Idade Média. São Leopoldo: Editora Unisinos. 2003. p. 44-61.

HECKER, J. F. C. The epidemics of the Middle Ages. London: George Woodfall and Son, 1844.

HARRELL, Richard Slade (Ed.). A dictionary of moroccan arabic. Washington, D.C.: Georgetown University Press, 2006.

HERÔDOTOS. História. Brasília: Editora Universidade de Brasília, 1985.

HESÍODO. Os trabalhos e os dias (Edição, tradução, introdução e notas de Alessandro Rolim de Moura). Curitiba: Editora Segesta, 2012.

HIMMICH, Ben Salem. Penser la dépression: partant d'Ibn Khaldûn. Rabat: Edino, 1987.

HOBBES, Thomas. Os elementos da lei natural e política: tratado da natureza humana, tratado do corpo político. São Paulo: Ícone, 2002. (Col. Fundamentos do Direito).

. Leviatã ou matéria, forma e poder de um Estado eclesiástico e civil. Trad. João Paulo Monteiro e Maria Beatriz Nizza da Silva. São Paulo: Nova Cultural, 1997. (Col. Os Pensadores).

HODGSON, Marshall G. S. The venture of Islam - Conscience and history in a world civilization. Vol. II The expansion of Islam in the middle periods. Chicago: The University of Chicago Press, 1977.

HOUAISS, Antônio. Dicionário Houaiss da língua portuguesa. Rio de Janeiro, Ed. Objetiva, 2001. 
HOURANI, A. O pensamento árabe na era liberal (1798-1939). São Paulo: Companhia das Letras, 2005.

2001.

Uma história dos povos árabes, São Paulo: Companhia das Letras,

HOWARD, Michael $\mathrm{C}$. Transnacionalism in ancient and medieval societies: The role of cross-border trade and travel. Jefferson, North Carolina: McFarland \& Company, Inc, 2012.

HRBEK, I. A desintegração da unidade política do Magreb. In: NIANE, Djibril Tamsir (Ed.). História geral da África IV: África do século XII ao XVI. Brasília: Unesco, 2010. p. 89-115.

HUME, D. Political discourses. Edinburg: Printed by R. Fleming for A. Kincaid, 1752).

HUNT, S. Edwin; MURRAY, James M. A history of business in medieval Europe, 1200-1550. Cambridge: Cambridge University Press, 1999.

IGGERS, Georg (Ed.); WANG, Q. Edward (Ed). Turning points in historiography: A cross-cultural perspective. New York: University of Rochester Press, 2002.

ISKANDAR, Jamil Ibrahim. Al-Qur'an: o Corão, o Livro Divino dos Muçulmanos. In: O islã clássico: itinerários de uma cultura. PEREIRA, Rosalie Helena de Souza (Org.). São Paulo: Editora Perspectiva S.A., 2007.

ISSAWI, C. An arab philosophy of history - Selections from the Prolegomena of Ibn Khaldun of Tunis (1332-1406). London: John Murray, 1950.

JACKSON, T. G, Sir. Gothic Architecture in France, England, and Italy. Vol II. Cambridge: Cambridge University Press, 1915.

JAEGER, W. Aristóteles. México: Fondo de Cultura Econômica. México, 1995.

JALDUN, I. Introducción a la historia universal. México: Fondo de Cultura Economica, 1997.

JOLIVET, J., "The Arabic inheritance". In: DRONKE, P. (ed.), A history of twelfthcentury western philosophy. Cambridge: Cambridge University Press, 1988, p. 113148.

KAWTHARANI, W. Al-Mujtma' al-madani wa al-dawla fi al-ta'rikh al-'arabi [Sociedade civil e Estado na história árabe]. In: Al-Mujtma' al-madani fi al-watan al'arabi wa dawruhu fi tahqiq al-dimuqratiyya [Sociedade civil no mundo árabe e seu papel na realização da democracia]. Center for Arab Unity Studies. Beirute: Center for Arab Unity Studies, 1992. p. 119-131.

KEYNES, J. M. General theory of employment, interest and money. New York: Harcourt, Brace and Co., 1936.

KNYSH, A. D. Ibn 'Arabi in the later Islamic tradition: the making of a polemical image in medieval Islam. Albany: State University of New York Press, 1999.

KRAYE, J.; RYAN, W. F.; SCHMITT, C. B. (org.). Pseudo-Aristotle in the Middle Ages: The 'Theology' and other texts. London: The Warburg Institute, 1986. 
KROEBER, A. L. Stimulus Diffusion. In: American anthropologist t. 42, janeiromarço, New York, 1940, p. 1-20.

KOUTSOYIANNIS, Anna. Modern microeconomics, Mcmillan, London, 1979.

LACOSTE, Yves. Ibn Khaldoun, naissance de l'histoire, passé du tiers monde. Paris: Éditions La Découverte, 1966.

LALLEMENT, M. História das ideias sociológicas: das origens a Max Weber. Petrópolis: Editora Vozes, 2003.

LAMBTON, A. State and government in medieval Islam: An introduction to the study of Islamic political theory: the jurists. London Oriental Series. Vol. 36. New York: RoutledgeCurzon, 1991.

LE GOFF, J. Para um novo conceito de Idade Média: tempo, trabalho e cultura no Ocidente. (Imprensa Universitária, n.14). Lisboa: Estampa, 1980.

LE GOFF, Jacques; SCHMITT, Jean-Claude. Dicionário temático do Ocidente Medieval. Bauru, São Paulo: Edusc; São Paulo: Imprensa Oficial do Estado, 2002. 2 v.

LE GOFF, J. A Idade Média e o dinheiro. Rio de Janeiro: Civilização Brasileira, 2014.

LEROI, Armand Marie. The lagoon: How Aristotle invented science. London: Bloomsbury Publishing, 2014.

LEWIS, Bernard. Islam in history: ideas, people, and events in the Middle East. Chicago: Open Court, 1993.

2010.

A descoberta da Europa pelo islã. São Paulo: Editora Perspectiva,

LINTON, Ralph. O homIn: uma introdução à antropologia. São Paulo: Livraria Martins Editora, 1959.

LIZANA, Antonio Garcia. Economic cycles: prosperity, depression, recovery. In: MOLINS, María Jesús Viguera (coord). Ibn Khaldun: The Mediterranean in the 14th century: rise and fall of empires. Sevilha: Foundation El Legado Andalusí e Foundation José Manuel Lara, 2006.

LOHR, Charles. Ramon Lull: atividade de Deus e harmonização do mundo. In: BLUM, Paul Richard (Org.). Filósofos da Renascença. São Leopoldo: Editora Unisinos, 2000.

LORD, Cannes; O'CONNOR, David, K (Ed.). Essays on the foundations of Aristotelian political science. Berkeley: University of California Press, 1991.

LOWRY, S. T. Ancient and Medieval Economics. In: SAMUELS, Warren J. (Ed.); BIDDLE, Jeff E. (Ed.); DAVIS, John B. (Ed.). A companion to the history of economic thought. Oxford: Blackwell Publishing Ltd, 2003. p. 11-27.

LULAT, Y. G-M. A history of African higher education from antiquity to the present - A critical synthesis. Westport, Connecticut: Praeger Publishers, 2005.

MAHDI, M. Ibn Khaldun's philosophy of history: A study in the philosophic foundation of the science of culture. New York: Routledge, 2016. 
MAMDANI, M. Reading Ibn Khaldun in Kampala. Makerere Institute of Social Research (MISR) Working Paper, Kampala, Número 10, Ago.2012 $<$ http://misr.mak.ac.ug/sites/default/files/publications/10Reading\%20Ibn\%20Khaldun $\%$ 20in\%20Kampala.pdf $>$. Acesso em 22.jul.2013.

MANZ, Beatrice Forbes. The rise and rule of Tamerlane. New York: Cambridge University Press (Canto Edition), 1999.

MAQUIAVEL, Nicolau. Discursos sobre a primeira década de Tito Lívio. São Paulo: Editora Martins Fontes, 2007.

. A arte da guerra. São Paulo: Editora Martins Fontes, 2006.

. História de Florença. São Paulo: Editora Martins Fontes, 2007.

O Príncipe. São Paulo: Editora Martins Fontes, 2007.

MARGOLIOUTH, D. S. Maomé e a Ascensão do Islã. Rio de Janeiro: Editora Contraponto, 2012.

MARKS, Geoffrey. The medieval plague: The Black Death of the Middle Ages. Nova York: Doubleday, 1971.

MARX, K. \& ENGELS, F. A ideologia alemã (Feuerbach). São Paulo: HUCITEC. $11^{\text {a }}$ Edição. 1999.

MARX, K. O capital. Abril Cultural. São Paulo. 1983.

1983.

O capital: crítica da economia política. São Paulo: Abril Cultural,

Introdução à crítica da economia política. In: Para a Crítica da Economia Política. Trad. Port. São Paulo: Abril, 1974. p. 109-125 (Col. Os Pensadores).

. Salário, preço e lucro. In: Para a Crítica da Economia Política. Trad. Port. São Paulo: Abril, 1974. p. 109-125 (Col. Os Pensadores).

MARX, K; ENGELS, F. A ideologia alemã. São Paulo: Boitempo Editorial, 2007.

MEIHY, Murilo Sebe Bon. Leão Africano: A África e o Renascimento vistos por um árabe. Cotia: Ateliê Editorial, 2017.

MIQUEL, André. La géographie humaine du monde musulman jusqu'au milieu du 11e siècle: Tome II : Géographie arabe et représentation du monde : la terre et l'étranger. 3 ed. Paris: Éditions de l'École des Hautes Études en Sciences Sociales (EHESS), 2001.

MOHAMED, Yasien. The division of labor and its theoretical foundation - Comparing Ibn Khaldun and Andam Smith. In: KIZILKAYA, Necmettin. Labor in an islamic setting: Theory and Practice. New York: Routledge, 2017.

NAPOLEONI, C. Smith, Ricardo e Marx. Rio de Janeiro: Graal, 1983.

NASCIMENTO, C.A. O que é filosofia medieval. São Paulo: Ed. Brasiliense, 1992.

NASSAR, N. La pensée réaliste d'Ibn Khaldun, Paris: PUF, 1967.

$114,1964$.

. Le Maître d'Ibn Khaldun: Al-Abili. Studia Islamica, Paris, n. 20, p. 103- 
NORWICH, John Julius. A history of Venice. New York: Vintage Books, 1989.

NÚÑES, C. E.; TORTELLA, G. Economic development and the problems of national state formation: the case of Spain. In: TEICHOVA, Alice (Ed.); MATIS, Herbert (Ed.). Nation, state, and the economy in history. Cambridge: Cambridge University Press, 2003, p. 113-131.

O'LEARY, D. L. E. How Greek science passed to the Arabs. Londres: Routledge \& Kegan Paul Ltd. 1979.

OliveIRA, R.; GENNARI, A. M. História do Pensamento Econômico. São Paulo: 8Editora Saraiva, 2009.

ORGANIZAÇÃO MUNDIAL DA SAÚDE. Setembro de 2016. Fact sheet, set.2016. Disponível em: <http://www.who.int/mediacentre/factsheets/fs267/en/>. Acesso em: 12.out.2016.

PEREIRA, Luiz Cézar Ramos. Costume internacional: gênese do direito internacional. Rio de Janeiro: Renovar, 2002.

PERSRAM, N. Postcolonialism and political theory. Lexington Books, Plymouth, UK. 2008.

PINES, Shlomo. Collected works of Shlomo Pines - Studies in Arabic versions of Greek texts. (Vol. II). Leiden: E. J. Brill, 1986.

PLATÃO. A República. 9 ed. Lisboa: Fundação Calouste Gulbenkian, 2001.

POLYBIUS. The histories. Translated by W. Platon. London: Loeb Classical Library, 1923.

POMIAN, Krysztof. Ibn Khaldûn au prisme de l'Occident. Bibliothèque des Histoires. Paris: Editions Gallimard, 2006.

PRICE, B.B. (Ed.). Ancient economic thought (Vol. 1). Londres: Routledge, 1997.

RABI, Muhammad Mahmoud. The political theory of Ibn Khaldun. Leiden: E. J. Brill, 1967.

REDFIELD, Robert. The folk society. In: American Journal of Sociology, Vol. 52, No. 4 (Jan., 1947), p. 293-308. Chicago: The University of Chicago Press, 1947.

REIS, Eliana Lourenço de L. Pós-colonialismo, identidade e mestiçagem cultural: a literatura de Wole Soyinka. Rio de Janeiro: Relume Dumará, 1999.

RENN, J (Ed.). The globalization of knowledge in history. Max Planck research library for the history and development of knowledge. Berlim: Edition Open Acess. 2012. E-Book. ISBN 978-3-8442-2238-8. Disponível em: <http://www.edition-openaccess.de/studies/1/1/index.html>. Acesso em. 17.out.2015

RICARDO, David. Princípios de economia política e tributação - Coleção Os Pensadores. São Paulo: Abril Cultural, 1979.

ROBERTSON, K. (Ed.); UEBEL, M. (Ed). The Middle Ages at Work. New York: Palgrave Macmillan, 2004.

RODINSON, M. Islam and capitalism. New York: Pantheon Books, Random House, 1974. 
RUSKIN, J. A economia política da arte. Rio de Janeiro: Editora Record, 2004.

SAID, Edward W. Cultura e imperialismo. São Paulo: Companhia das Letras, 2005.

SAIDI, O. A unificação do Magreb sob os Almóadas. In: NIANE, Djibril Tamsir (Ed.). História geral da África IV: África do século XII ao XVI. Brasília: Unesco, 2010. p. 17-63.

SCHMITTHOFF, Clive. M. Select essays on international trade law. London: Graham \& Trotman, 1988

SCHUMPETER, J. A., History of economic analysis. New York: Oxford University Press, 1954.

SÊNECA. Euvres complètes de Sénèque le philosophs. Paris: J. J. Dubochet et Cie, 1838.

SHATZMILLER, Maya. Labour in the medieval Islamic world. Leiden: EJ. Brill, 1994.

SMITH, Adam. Investigação sobre a natureza e as causas da riqueza das nações. São Paulo: Abril Cultural, 1979.

York: Random House, 1937.

. An inquiry into the nature and causes of the wealth of nations. New

SPANGLER, Mary Michael. Aristotle on teaching. Lanham, Maryland: University Press of America, Inc., 1998

SPENGLER, J. J. Economic thought in Islam: Ibn Khaldun. Comparative Studies in Society and History, vol. 6, no. 3.

STÖRIG, Hans Joachim. A aventura das línguas - Uma viagem através da história dos idiomas do mundo. São Paulo: Melhoramentos, 1990.

SIVASUNDARAM, S. Islanded: Britain, Sri Lanka, and the bounds of an Indian Ocean colony. The University of Chicago Press. Chicago. 2013.

SUN, G.-Z. The division of labour in economics: a history - Routledge studies in the history of economics. New York: Routledge, 2014.

SWAIN, Simon. Economy, family, and society from Rome to Islam: A critical edition, english translation, and study of Bryson's management of the estate. Cambridge: Cambridge University Press, 2013.

TALBI, M. A expansão da civilização magrebina: seu impacto sobre a civilização ocidental. In: NIANE, Djibril Tamsir (Ed.). História geral da África IV: África do século XII ao XVI. Brasília: Unesco, 2010, p. 65-87.

TOCQUEVILlE, Alex de. A democracia na América. São Paulo: Editora da Universidade de São Paulo. 1987

TRAKMAN, Leon E. The law merchant: The evolution of commercial law. Littleton, Colorado: Fred B. Rothman \& Co., 1983.

TROMPF, G.W. The idea of historical recurrence in western thought: From Antiquity to the Reformation. Berkeley: University of California Press, 1979. 
TUBB, Jonathan N. Canaanites - Peoples of the past series. London: University of Oklahoma Press, 1998.

TURCHIN, Peter. Historical dynamics: why states rise and fall. Princeton: Princeton University Press, 2003.

VERNANT, Jean-Pierre. Mito e pensamento entre os gregos. 2 ed. São Paulo: Editora Paz e Terra, 2002.

XENOFONTE. Mémorables. Tradução Louis André Dorion. Paris: Les Belles Lettres, 2010.

WEISS, D. Ibn Khaldun on Economic Transformation. International journal of Middle East studies, Cambridge University Press, Vol. 27, N. 1, 1995. p. 29-37.

WELCH, Patrick J.; WELCH, Gerry F. Economics: theory and practice. Hoboken, New Jersey: John Wiley \& Sons, Inc., 2010.

ZAINDAN, Assaad. Letras e história: mil palavras árabes na língua portuguesa. 2 ed. São Paulo: Escrituras Editora e Edusp, 2010.

$\Pi \Lambda \mathrm{AT} \Omega$ N. Platonis philosophi quae exstant - Platonis opera, Volumen Quintum. Zweibrücken: Biponti Typographia Societatis Bipontinae, 1784. 